\title{
ANÁLISE DO FLUXO DE TRANSPORTE RODOVIÁRIO DE TORAS CURTAS DE EUCALIPTO PARA ALGUMAS INDÚSTRIAS DE CELULOSE E DE CHAPAS DE COMPOSIÇÃO NO ESTADO DE SÃO PAULO
}

\author{
ROBERTO ANTONIO TICLE DE MELO E SOUSA \\ Engenheiro Florestal
}

Orientador: Prof. Dr. LUIZ CARLOS ESTRAVIZ RODRIGUEZ

\begin{abstract}
Tese apresentada à Escola Superior de Agricultura "Luiz de Queiroz", Universidade de São Paulo, para obtenção do titulo de Doutor em Cièncias, Área de Concentração: Economia Aplicada.
\end{abstract}

PIRACICABA

Estado de São Paulo - Brasil

Outubro - 2000 


\section{Dados Internacionais de Catalogação na Publicação (CIP) DIVISÃO DE BIBLIOTECA E DOCUMENTAÇÃO - Campus "Luiz de Queiroz"/USP}

Sousa, Roberto Antonio Ticle de Melo e

Análise do fiuxo de transporte rodoviário de toras curtas de eucalipto para algumas indústrias de celulose e de chapas de composição no estado de São Paulo / Roberto Antonio Ticle de Melo e Sousa. - - Piracicaba, 2000.

$115 \mathrm{p}$.

Tese (doutorado) - Escola Superior de Agricultura Luiz de Queiroz, 2000.

Bibliografia.

1. Celulose de eucalipto 2. Custo operacional 3. Indústria de papel e celulose 4 . Pesquisa operacional 5. Planejamento florestal 6. Programação linear 7. Transporte florestal I. Título

CDD 388.1 


\section{AGRADECIMENTOS}

Ao meu Senhor e meu Deus.

Aos meus pais Emílio e Julieta, uma vida de exemplos de união, força, fé e perseverança.

À minha família Márcia, Cristiano, Caroline e Camilo, pela compreensão, pelo incentivo e presença constantes.

À Universidade Federal de Mato Grosso e à Faculdade de Engenharia Florestal.

Ao Departamento de Economia, Administração e Sociologia da ESALQ/USP pela oportunidade.

À CAPES/PICDT pelo suporte financeiro.

Ao professor Luiz Carlos Estraviz Rodriguez, pela confiança, incentivo e firmeza transmitidos ao longo da orientação deste trabalho.

Aos colegas e técnicos do Laboratório de Métodos Quantitativos do Departamento de Ciências Florestais da ESALQ/USP e da Coordenação de Processamento de Dados da UFMT, pela inestimável contribuição, agradável convivência, disponibilidade e apoio.

Ao Instituto de Pesquisas Florestais (IPEF), nas pessoas do engenheiro florestal Edward e da secretária Bianca, pelo suporte logístico e financeiro.

Às empresas participantes deste trabalho, pelo pronto atendimento às inúmeras solicitações feitas.

Aos professores Fernando Seixas e José Vicente Caixeta Filho, pela cooperação e sugestões apresentadas.

Aos convidados da banca examinadora Prof. João Alexandre Widmer e Prof. Gilberto Sisto Fernandez, pela contribuição em participar da avaliação deste trabalho.

Aos funcionários do DEAS/ESALQ/USP, nas pessoas de Maiélle, Márcia e Lú, que na convivência fraterna tomaram menos árdua a caminhada.

Aos colegas de curso, pela solidariedade, bom humor e companheirismo.

"Não basta ensinar ao homem uma especialidade, porque se tornará assim uma máquina utilizável e não uma personalidade. É necessário que adquira um sentimento, um senso prático daquilo que vale a pena ser empreendido, daquilo que é belo, do que é moralmente correto." (Albert Einstein) 
Ao meu pai Emílio e ao mano Zé, agricultores por vocação aqui na Terra e hoje nos campos do Senhor.

\section{Dedico}




\section{SUMÁRIO}

LISTA DE FIGURAS

Página

LISTA DE TABELAS

vii

RESUMO

SUMMARY

1 INTRODUÇÃ

1.1 O problema..................................................................................................................................

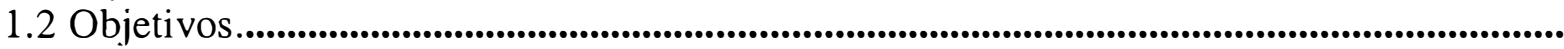

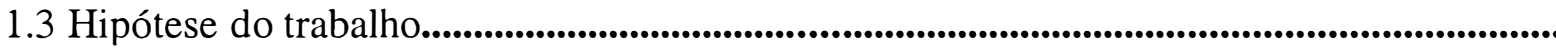

1.4 Estrutura do trabalho...................................................................................................................

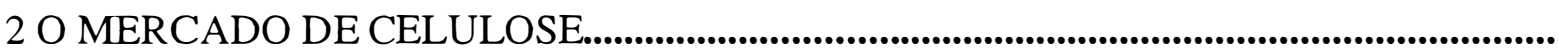

3 O MERCADO DE CHAPAS DE COMPOSIÇÃ

4 O CUSTO DE TRANSPORTE NO ABASTECIMENTO DE MADEIRA...........................

5 A UTILIZAÇÃO DE PROGRAMAÇÃO LINEAR NA ANÁLISE DO TRANSPORTE

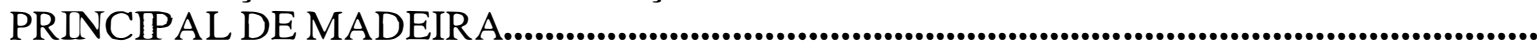

5.1 Histórico......................................................................................................................................................

5.2 Performance dos modelos de otimização aplicados ao transporte principal de madeira.....

6 MATERIAL E MÉTODOS......................................................................................................

6.1 Caracterização do fluxo de transporte de madeira realizado..................................................

6.2 Caracterização dos modelos de otimização d o fluxo de transporte de madeira...................

6.3 Modelo de transporte com várias origens e vários destinos, sem definição do tipo de caminhão (Modelo I).

viii

$\mathrm{x}$

xii

6.3.1 Formulação teórica do Modelo I.

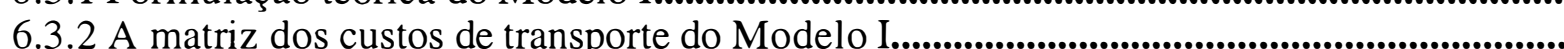

6.3.3 Formulação matemática do Modelo I...............................................................................

6.3.4 Pressuposições e limitações do Modelo I..

6.4 Modelo de transporte com várias origens e vários destinos, definindo o tipo de caminhão (Modelo II).

6.4.1 Formulação teórica do Modelo II.....

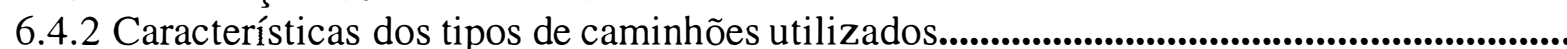

6.4.3 A matriz dos custos de transporte do Modelo II.....................................................................

6.4.4 Cálculo dos fatores de correção $\left(f_{i i k}\right)$...............................................................................................

6.4.5 Estimativa do número de viagens realizadas..................................................................................

6.4.6 Formulação matemática do Modelo II....................................................................................

6.4.7 Pressuposições e limitações do Modelo II....................................................................................

6.5 Modelo de transporte individualizado com várias origens e um único destino, sem definição do tipo do tipo de caminhão 


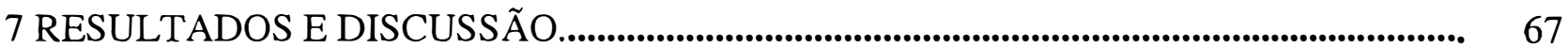

7.1 Transporte realizado (Realizado) versus solução ótima do Modelo I........................................ 77

7.2 Transporte realizado (Realizado) versus solução ótima do Modelo II...................................... $\quad 80$

7.3 Solução ótima do Modelo I versus solução ótima do Modelo II................................................ 83

7.4 Solução ótima dos modelos: bom para os lucros e para o meio ambiente............................... $\quad 85$

7.5 Champion Papel e Celulose Ltda..................................................................................................... 87

7.6 Duratex S/A ................................................................................................................................. 89

7.7 Eucatex S/A .................................................................................................................... 90

7.8 Lwarcel Celulose e Papel Ltda............................................................................................................. 91

7.9 Ripasa S/A .................................................................................................................. 92

7.10 Cia. Suzano de Papel e Celulose..................................................................................................... 93

7.11 Perspectivas de entendimento entre indústrias no processo de trocas................................... 94

8 CONCLUSÕES............................................................................................................ 100

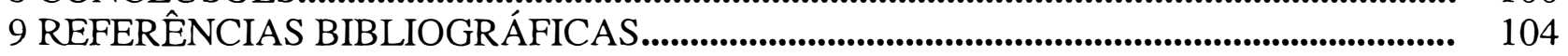




\section{LISTA DE FIGURAS}

Figura 1 - Estratificação da madeira industrial............................................................................... 3

Figura 2 - Distribuição espacial das indústrias e respectivas fontes de abastecimento....... 20

Figura 3 - Representação gráfica do problema de transporte com várias origens e vários destinos (Modelo I).........................................................................................................

Figura 4 - Representação gráfica do problema de transporte com várias origens e vários destinos, incluindo a op̧̧ão tipo de caminhão (Modelo II)..................................... 51

Figura 5 - Tipos de caminhão utilizados pelas indústrias no transporte principal de toras curtas de eucalipto............................................................................................. 53

Figura 6 - Representação gráfica do problema de transporte com várias origens e um

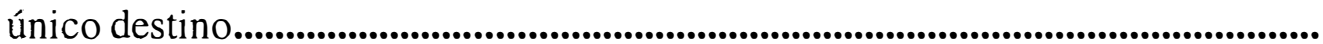




\section{LISTA DE TABELAS}

Tabela 1 - Contribuição brasileira à produção mundial de madeira processada............. 1

Tabela 2 - Produção do setor florestal brasileiro por segmento.......................................... 2

Tabela 3 - Produção brasileira de celulose no período de 1970 a 1996.......................... 10

Tabela 4 - Resultado econômico da atividade industrial brasileira de celulose e papel no ano de 1996............................................................................................ 11

Tabela 5 - Volume anual de madeira efetivamente recebido no pátio das indústrias de celulose e papel (st)............................................................................................. 12

Tabela 6 - Taxa estimada de crescimento do consumo mundial de madeira industrial no período de 1985 a 2005.................................................................................. 14

Tabela 7 - Base florestal necessária para suprir o mercado brasileiro de chapas de composição e celulose............................................................................................... 15

Tabela 8 - Custo médio da exploração de madeira para celulose e papel....................... 22

Tabela 9 - Indústrias envolvidas no estudo e respectivos municípios de atuação...........

Tabela 10 - Planilha para coleta de dados de transporte principal de toras curtas de eucalipto...................................................................................................................... 37

Tabela 11 - Terminologia utilizada no Modelo I...................................................................... 40

Tabela 12 - Valores de fretes para o transporte principal de toras curtas de eucalipto, em R $\$ /$ t./Km, referentes ao ano de 1996....................................................... 42

Tabela 13 - Distâncias em quilômetros para o transporte principal nas rotas de abastecimento disponíveis no ano de 1996......................................................

Tabela 14 - Matriz dos custos de transporte rodoviário de toras curtas de eucalipto (R\$/t.) no estado de São Paulo para o ano de 1996........................................ 45

Tabela 15 - Terminologia utilizada no Modelo II................................................................. 50

Tabela 16 - Matriz dos custos de transporte da tonelada de toras curtas de eucalipto por rota e por tipo de caminhão.................................................................................... 
Tabela 17 - Matriz dos custos de viagem no transporte de toras curtas de eucalipto por rota e por tipo de caminhão...........................................................................

Tabela 18 - Valores realizados pelas indústrias no transporte rodoviário de toras curtas de eucalipto no ano de 1996 (Realizado)............................................

Tabela 19 - Valores otimizados do modelo de transporte para toras curtas de eucalipto, sem definição do tipo de caminhão (Modelo I).

Tabela 20 - Valores otimizados do modelo de transporte para toras curtas de eucalipto, definindo o tipo de caminhão (Modelo II).....................................

Tabela 21 - Valores individualmente otimizados do modelo de transporte para toras curtas de eucalipto, sem definição do tipo de caminhão (Modelo III).........

Tabela 22 - Número de origens (fazendas) por destino nas diferentes soluções apresentadas pelos modelos..........................................................................

Tabela 23 - Desempenho econômico, medido pelo custo anual total e unitário de transporte, das diferentes soluções apresentadas pelos modelos..................

Tabela 24 - Desempenho operacional, medido pelo volume e quilometragem percorrida em cada solução apresentada pelos Modelos...............................

Tabela 25 - Listagem e ordem das indústrias segundo os impactos nos custos totais de

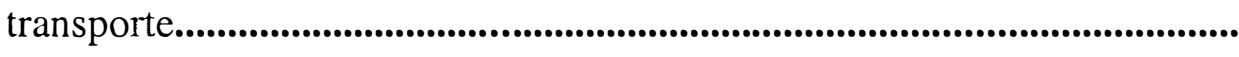

Tabela 26 - Listagem e ordem das indústrias segundo os impactos na quilometragem percorrida........................................................................................

Tabela 27 - Ganhos de eficiência operacional e econômica devido à adoção da variável tipo de transporte.

Tabela 28 - Ganhos de eficiência operacional e econômica devido à quebra do vínculo de propriedade da madeira....................................................................... 


\title{
ANÁLISE DO FLUXO DE TRANSPORTE RODOVIÁRIO DE TORAS CURTAS DE EUCALIPTO PARA ALGUMAS INDÚSTRIAS DE CELULOSE E DE CHAPAS DE COMPOSIÇÃO NO ESTADO DE SÃO PAULO
}

\author{
Autor : ROBERTO ANTONIO TICLE DE MELO E SOUSA \\ Orientador: Prof. Dr. LUIZ CARLOS ESTRAVIZ RODRIGUEZ
}

\section{RESUMO}

O trânsito de caminhões em rotas opostas transportando toras curtas de eucalipto nas rodovias paulistas, é indicativo da existência de ineficiências no transporte desta matéria prima para o abastecimento das indústrias do setor florestal no estado. A rapidez nos fluxos de transporte, a crescente competitividade dos mercados, as exigências de padrões de qualidade e as expectativas da sociedade quanto ao meio ambiente, são apontados como fatores que tornam urgente a necessidade de se desenvolver e estudar processos de tomada de decisão com recursos de otimização, que apóiem a atividade de planejamento do transporte principal de madeira. Com o objetivo de analisar e avaliar a eficiência deste tipo de transporte, o estudo envolve quatro indústrias de celulose e papel e duas de chapas de composição cujas matérias-primas são toras curtas de eucalipto provenientes exclusivamente de florestas plantadas. Foram delineados três modelos de transporte utilizando programação linear. Os resultados das soluções ótimas destes três modelos expressos em termos de custos, toneladas transportadas e quilômetros percorridos, são comparados entre si e com o transporte de madeira efetivamente realizado por estas seis indústrias no ano de 1996. O primeiro modelo desconsidera o vínculo de propriedade entre indústrias e povoamentos, o segundo mantém a desconsideração deste vínculo e insere a opção de uso de diferentes tipos de caminhões para proceder ao transporte principal. A perspectiva individual com 
ausência de competição na demanda por madeira, caracteriza o comportamento do terceiro modelo que trata cada indústria isoladamente. Os três modelos e o transporte efetivamente realizado definem quatro cenários onde os resultados são analisados comparando-se primeiramente o comportamento do conjunto das seis indústrias e em seguida o comportamento individual de cada uma delas. Todas as indústrias participam do processo de trocas com índices individuais que variam entre $33 \%$ e $80 \%$. As soluções ótimas dos dois primeiros modelos apresentam para o conjunto, percentuais de trocas de fontes de abastecimento de $62,1 \%$ e $64,9 \%$, acompanhados de reduções nos custos totais de transporte de respectivamente $12,8 \%$ e $29,6 \%$. Individualmente as indústrias apresentam nos modelos, reduções no custo total de transporte que variam entre $5 \%$ e $52,4 \%$. Ao avaliar a contribuição da variável "tipo de transporte" tanto por indústria como para o conjunto, a magnitude dos resultados obtidos questiona o processo de "terceirização" do transporte principal de madeira largamente difundido entre as empresas. Os resultados sugerem que a "verticalização" deste transporte, traz embutida uma opção administrativa que leva a consideráveis ganhos de competitividade devido à existência de margens de eficiência operacional e econômica ainda não exploradas. 


\title{
ANALYSIS OF THE TRUCK TRANSPORTATION FLOW OF SHORT EUCALYPTUS LOGS FOR SOME PAPER MILLS AND WOOD PANEL COMPANIES IN THE STATE OF SÃO PAULO
}

\author{
Author : ROBERTO ANTONIO TICLE DE MELO E SOUSA \\ Adviser: Prof. Dr. LUIZ CARLOS ESTRAVIZ RODRIGUEZ
}

\section{SUMMARY}

The movement of trucks on opposite routes transporting short eucalyptus logs on São Paulo highways in Brazil indicates transportation inefficiencies. Increasing flow speed on the transportation network, raising competition among companies in the market, increasing quality standards and demanding greater environmental regulations, were identified as factors that contribute to the need for studying and applying decisionsupport systems based on optimizing techniques. Four pulp and paper mills and two wood panel companies, consumers of Eucalyptus short logs harvested from plantations in the State of São Paulo, were involved in this study to provide the necessary data for evaluation of the transportation network utilized. Three linear programming transportation models were developed. The optimal solutions presented by these models and the actual log displacement for these six companies in 1996, evaluated in terms of cost, transported weight and kilometers traveled. The first model ignored property rights between forest plantations and companies. The second model also ignored property rights, but included the use of different truck types as alternatives in each transportation

route. The third model was used six times, one for each company independent of considering the plantations available. However, on each run the existence of the other companies was ignored. The three models and the transportation strategy actually implemented by the six companies defined four scenarios. Initially, the outcomes 
considering all six companies were analyzed followed by an analysis of each individual outcome. Given unconstrained property rights, exchange of raw material was recommended by the models with rates that varied from $33 \%$ to $80 \%$ among companies. The optimal solutions of models 1 and 2 presented indices for the whole system that varied between $62.1 \%$ and $64.9 \%$ respectively, with total cost reductions of $12.8 \%$ and $29.6 \%$. According to each model, individual companies can benefit with cost reductions varying between $5 \%$ and $52.4 \%$. The analysis of the "truck type" variable either for the whole system or each individual company, raised questions about the adequacy of contracting transportation services by third-party contractors. The results showed that vertical transportation strategies, commonly adopted in the past and practically abandoned nowadays, could inherently offer operational and monetary gains not completely available otherwise. 


\section{INTRODUÇÃO}

No ano de 1996 o setor florestal no Brasil movimentou cerca de 16,5 bilhões de dólares, envolvendo no seu processo produtivo 1.200 .000 pessoas de maneira direta e indireta. O consumo anual foi da ordem de 285 milhões de metros cúbicos de madeira, dos quais $27 \%$ supridos por florestas de produção e em sua quase totalidade transportados por caminhões, que são responsáveis por cerca da metade dos custos da madeira posta fábrica. Neste mesmo ano, o setor como um todo participou com $2,2 \%$ na formação do produto interno bruto (PIB) e com 6,6\% no valor total das exportações (Dassie, 1996).

Quanto à participação do mercado brasileiro junto ao mercado mundial, a Tabela 1 mostra o comportamento diferenciado destes dois segmentos estudados. O segmento brasileiro de chapas de composição participa de maneira expressiva, respondendo por $10 \%$ do volume transacionado no mercado mundial enquanto o de celulose entra com 1,7\%. Quando se considera o volume agregado da produção florestal brasileira no mercado mundial, a nossa participação gira em torno de 2,1\% deste mercado (Tomaselli, 1998).

Tabela 1. Contribuição brasileira à produção mundial de madeira processada

\begin{tabular}{lcc}
\hline \multicolumn{1}{c}{ Produto } & Produção $(1.000)$ & \% Produção mundial \\
\hline Serradas (folhosas e coníferas) & $18.230 \mathrm{~m}^{3}$ & 12,7 \\
Compensados & $1.650 \mathrm{~m}^{3}$ & 3,1 \\
Chapas de composição & $1.840 \mathrm{~m}^{3}$ & 10,1 \\
Polpa (Celulose) & $6.331 \mathrm{t}$. & 1,7 \\
Papel & $6.517 \mathrm{t}$. & 2,2 \\
\hline
\end{tabular}

Fonte: Adaptado de Tomaselli (1998) 
A demanda brasileira de madeira para o setor industrial projetada para o ano 2000 é de 95,4 milhões de metros cúbicos, sendo que praticamente a metade $(46,3$ milhões) vai para o setor de celulose e 9\% (8,5 milhões) vai para o setor de chapas de composição. Para atender a esta demanda, a indústria de madeira requer, naquele ano, uma base florestal da ordem de 9,7 milhões de hectares de florestas plantadas e para o ano 2010, 14,7 milhões de hectares (Associação Brasileira de Produtores de Madeira, 1995).

A característica física da matéria-prima básica industrial tanto para celulose quanto para chapas de composição é madeira sob forma de cavaco. As operações que antecedem o processamento da madeira na fábrica são bastante similares para ambas as atividades industriais, uma vez que a diferenciação entre os dois processos se dá após a operação de descarga do transporte principal (Figura 1).

Pode se observar pela Tabela 2 que os segmentos de celulose e de chapas de composição abordados neste estudo são os únicos que consomem matéria-prima madeira proveniente exclusivamente de florestas plantadas. Qualquer plano de expansão da capacidade produtiva das fábricas tem que vir acompanhado de aumento de produtividade e/ou de expansão de área plantada.

Tabela 2. Produção do setor florestal brasileiro por segmento.

\begin{tabular}{llllll}
\hline Segmento & Quantidade & Unidade & Ano & Origem & Fonte \\
\hline Carvão Veg. & $33,0 \times 10^{6}$ & m.d.c & 1995 & Abracave & Nativas+Plantadas \\
Celulose & $5,73 \times 10^{6}$ & t. & 1996 & ANFPC & Plantadas \\
Papel & $5,85 \times 10^{6}$ & t. & 1996 & ANFPC & Plantadas \\
Compensados & $1,90 \times 10^{6}$ & $\mathrm{M}^{3}$ & 1994 & Abimci & Nativas+Plantadas \\
Laminados & $510 \mathrm{mil}$ & $\mathrm{M}^{3}$ & 1994 & Abimci & Nativas+Plantadas \\
Chapas de F. & $700 \mathrm{mil}$ & $\mathrm{M}^{3}$ & 1994 & SBS & Plantadas \\
Aglomerados & $800 \mathrm{mil}$ & $\mathrm{M}^{3}$ & 1994 & Abipa & Plantadas \\
Mad. Serrada & $19,0 \times 10^{6}$ & $\mathrm{M}^{3}$ & 1992 & FAO & Nativas+Plantadas \\
Mad.emToras & $269,0 \times 10^{6}$ & $\mathrm{M}^{3}$ & 1992 & FAO & Nativas+Plantadas \\
\hline
\end{tabular}

Fonte: Adaptado de Dassie (1996)

Seguindo a estratificação industrial da madeira proposta por Keiner Jr. (1993), os segmentos estudados são Polpa e Chapas de composição (Figura 1). 


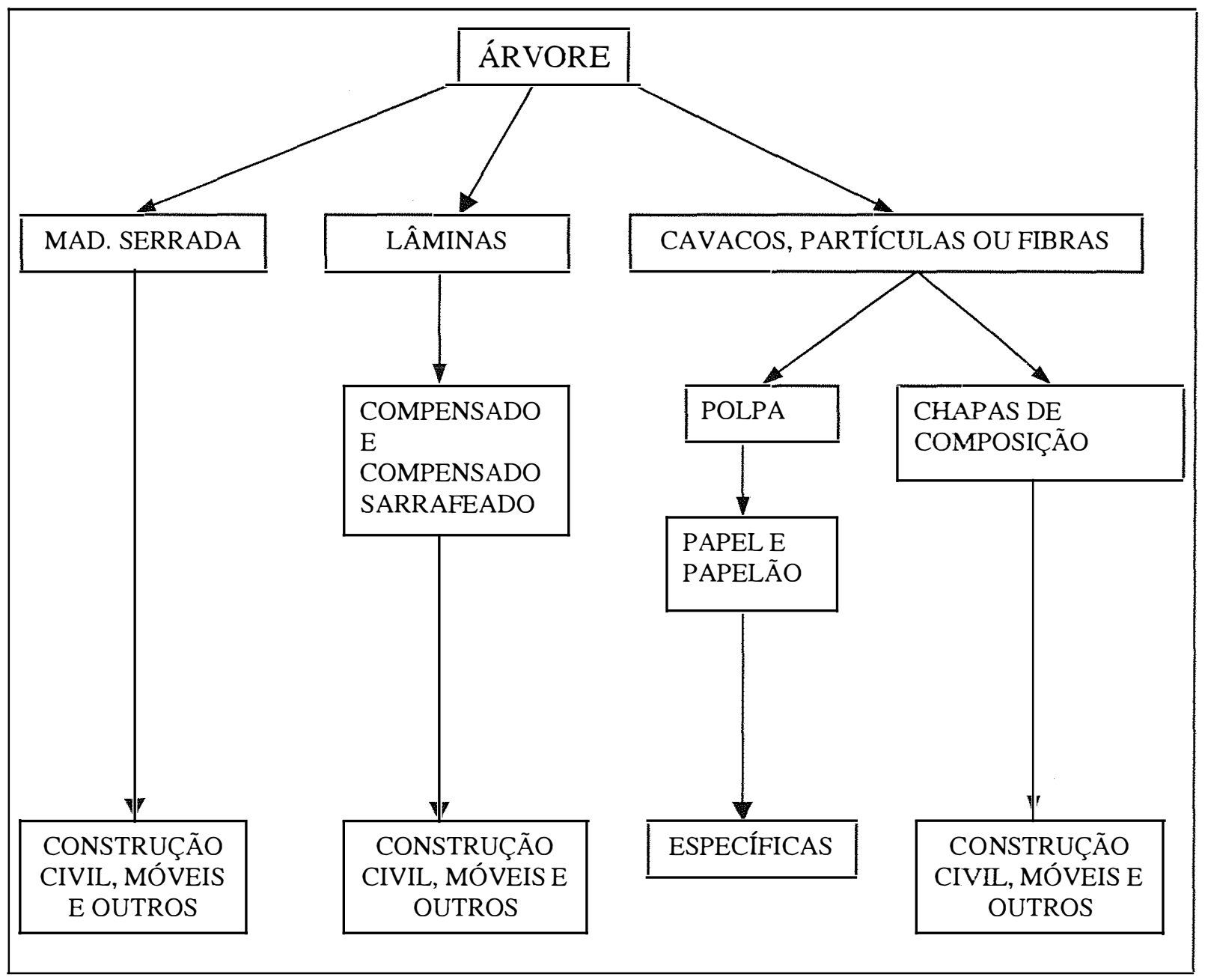

Fonte: Keiner Jr. (1993)

Figura 1 - Estratificação da madeira industrial

Uma base florestal sólida é fundamental para se ter uma indústria confiável. A moderna indústria brasileira da madeira está apoiada principalmente em plantios de espécies exóticas, o que soma atualmente um total aproximado de 4 milhões de hectares ou $0,5 \%$ da área total do país (Neves, 1998). 
Os números podem diferir, porém a tendência mostrada por todas as previsões é a mesma, antevendo para a próxima década taxas de crescimento positivas para o mercado de madeira tanto doméstico quanto mundial.

As expectativas na consideração conjunta do mercado brasileiro de celulose e de chapas de composição apontam para uma duplicação da demanda total por matériaprima na primeira década do próximo século. O reflexo esperado na economia e na rede rodoviária do estado de São Paulo é proporcional à sua importância dentro destes mercados, sendo que o estado responde em média por mais de $35 \%$ da produção nacional de celulose e de chapas de composição.

Martini \& Leite (1988) concordam que:

"qualquer expansão na capacidade de produção industrial do setor madeireiro terá equivalente aumento no consumo de matéria-prima madeira e caso haja necessidade de produção própria por indisponibilidade do mercado, será também equivalente o aumento da área de efetivo plantio necessária."

A capacidade de produção e de melhoria da qualidade do produto final apresentou, com o aumento da demanda e o desenvolvimento tecnológico, um rápido e contínuo crescimento, refletindo no aumento de área florestal plantada com grande dispersão geográfica em terras cada vez mais distantes. As indústrias de celulose e papel e de chapas de composição estão entre as que promovem maior distribuição espacial de florestas de produção. Como conseqüência, o custo do transporte principal de madeira tornou-se um dos mais importantes componentes do custo final desta matéria-prima na indústria.

Villela Filho (1992) sintetiza muito bem a motivação que levou ao desenvolvimento deste estudo quando considera a fase de exploração e transporte florestal como sendo o elo mais importante entre a floresta (estoque de fibra "in natura") e o mercado consumidor de fibra processada. As preocupações com a eficiência e a inovação são palcos de desafios e oportunidades de novas propostas para as futuras gerações dentro da economia florestal. 
A rapidez nos fluxos de transporte, a crescente competitividade dos mercados, as exigências de padrões de qualidade e as expectativas da sociedade quanto ao meio ambiente são apontados como fatores que tornam urgente o desenvolvimento e estudo dos processos de tomada de decisão, com recursos de otimização que apóiem a atividade de planejamento do transporte principal de madeira.

O estudo de logística aplicado no planejamento das operações de transporte da matéria-prima madeira e de distribuição da produção tem tido sua importância reconhecida na busca de maior eficiência e competitividade pelas indústrias nos mais variados segmentos da economia do setor florestal no mundo todo.

O tema abordado neste estudo tem sido tratado por diversos pesquisadores do setor florestal em diversos países: McGuigan (1984) na Austrália, Harstela (1997) na Finlândia, Carlsson \& Arvidsson (1998) na Suécia, Martell \& Weintraub (1998) no Chile, Gabarró et al. (1999) no Chile e Ross (2000) ${ }^{1}$ nos Estados Unidos, demonstrando a atualidade e a importância do assunto.

\subsection{O problema}

Diversas empresas do setor florestal no estado de São Paulo possuem suas fontes de abastecimento de madeira (fazendas) em origens distintas abrangendo áreas descontínuas dentro do estado. O planejamento da colheita e do transporte da madeira geralmente envolve o abastecimento de uma única unidade de consumo, com diferentes distâncias para cada uma das fazendas fornecedoras. Na realização do transporte rodoviário ocorre, por diversas vezes, o trânsito de caminhões em rotas opostas transportando o mesmo tipo de madeira para diferentes indústrias consumidoras.

O problema específico deste trabalho trata da provável existência de ineficiências no transporte principal de toras curtas de eucalipto realizado pelas

\footnotetext{
${ }^{1}$ Este último trabalho diz respeito ao abastecimento e distribuição de produtos e derivados da indústria petrolífera, porém se utilizando dos mesmos princípios, objetivos e métodos adotados nos modelos para matéria-prima madeira.
} 
indústrias no ano de 1996. São fazendas com diferentes capacidades de fornecimento de madeira, abastecendo indústrias igualmente diferentes em termos de localização e de demandas previamente definidas.

Este problema foi descrito pela primeira vez por Hitchcock em 1941, com o objetivo de minimizar o custo do fluxo dentro de uma rede de transporte. Dykstra (1984) e Williams (1993) consideram que, de maneira geral, o problema de transporte diz respeito ao deslocamento de mercadorias ou matéria-prima de múltiplos centros de fornecimento para múltiplos centros de consumo, segundo um custo mínimo.

\subsection{Objetivos}

O presente estudo tem como objetivo geral avaliar o transporte principal da matéria-prima "toras curtas de eucalipto" realizado por determinadas indústrias de celulose e de chapas de composição situadas no estado de São Paulo, com vistas a demonstrar a existência de margens de ganhos de eficiência na redistribuição espacial das fontes de abastecimento.

Como objetivos específicos, destacam-se:

a) Caracterizar o sistema de transporte principal de toras curtas de eucalipto praticado pelas indústrias no ano de 1996;

b) Propor fluxos de transporte alternativos através de modelos de transporte com base em técnicas de programação linear;

c) Propor um modelo de transporte, utilizando também técnicas de programação linear que incorpore a variável "tipo de caminhão" utilizado no transporte principal de madeira naquele ano; $\mathrm{e}$

d) Comparar o transporte principal praticado pelas indústrias no ano de 1996 com os resultados apresentados pelos modelos de otimização. 


\subsection{Hipótese do trabalho}

A redistribuição das fontes de abastecimento de toras curtas de eucalipto entre as indústrias consumidoras pode promover reduções nos custos do transporte principal desta matéria-prima, gerando oportunidades de ganhos de competitividade tanto para o agregado das indústrias (sistema) quanto para as indústrias individualmente.

\subsection{Estrutura do trabalho}

A importância do trabalho e seus possíveis desdobramentos ficam mais evidentes ao considera-lo sob dois enfoques distintos.

O primeiro, contido nos capítulos 2 e 3, resume a importância econômica dos segmentos estudados mostrando a representatividade e magnitude de suas participações nos cenários tanto estadual quanto nacional.

O segundo enfoque, abordado no capítulo 4, detém-se sobre o custo do transporte principal rodoviário e sua participação no custo da madeira industrial de uma maneira geral, sua caracterização e sua importância na composição dos custos finais de produção. Ainda nesse capítulo, são apresentadas diversas abordagens sobre o comportamento e participação deste tipo de custo em indústrias do setor florestal em diferentes partes do mundo.

O capítulo 5 apresenta um histórico e a evolução da utilização da técnica de programação linear em pesquisa operacional voltada para o setor florestal, com opiniões e propostas de diferentes autores, afunilando gradualmente para o uso específico no transporte rodoviário de madeira e finalizando com o enfoque deste trabalho.

O capítulo 6 descreve os diferentes cenários e as respectivas restrições que deram suporte aos modelos propostos neste estudo, o processo de modelagem, a construção e definição da base de dados para cada um dos modelos e apresenta o software utilizado na obtenção das soluções ótimas. 
Os resultados descritos no capítulo 7 são analisados e discutidos segundo os modelos utilizados, considerando-se primeiramente um sistema único composto das seis indústrias e suas trinta e duas fazendas Em seguida, analisa-se a situação individual de cada uma das indústrias, com um breve enfoque na questão ambiental.

O capítulo 8 sintetiza as principais conclusões do trabalho e traz sugestões de novas pesquisas. 


\section{O MERCADO DE CELULOSE}

O período dos incentivos fiscais ao reflorestamento garantiu o fornecimento de matéria prima para a expansão do setor de celulose e papel que enfrentaria flutuações do mercado interno na década de 80 . O crescimento e a diversificação do mercado, associados às vantagens comparativas tanto ambientais (clima, solo, etc.) quanto das características do produto nacional (fibras curtas de eucalipto), fizeram com que o Brasil passasse de importador nos anos 50 para auto-suficiência em 1957 e para a condição de grande produtor e exportador a partir da década de 80.

Pela Tabela 3, percebe-se que a produção total de celulose quadruplicou na década de 70, crescendo a uma taxa média anual de 16,11\% alavancado pela produção de celulose de fibra curta que quase quintuplicou neste mesmo período. Já no intervalo de 1980 a 1996, a produção total praticamente dobrou e cresceu a uma taxa média anual de $4,5 \%$, refletindo os quadros recessivos por que passaram as economias interna e externa.

A indústria de celulose e papel tem sido a locomotiva da modernização da indústria de produtos florestais no Brasil, ocupando hoje no mercado mundial, o $7^{\circ}$ e o $11^{\circ}$ lugares respectivamente. (Neves, 1998)

No ano de 1996 o PIB brasileiro somou 748 bilhões de dólares onde a indústria de celulose e papel isoladamente contribuiu com 1\% (Tabela 4). De um total de 52,6 bilhões de dólares em exportações para o mesmo ano, a indústria de celulose e papel foi responsável por 1,89\% deste total (Conjuntura Econômica, 1997). 
Tabela 3- Produção brasileira de celulose para o período de 1970 a 1996.

\begin{tabular}{|c|c|c|c|c|}
\hline \multirow[t]{2}{*}{ Ano } & \multicolumn{3}{|c|}{ Produção (t.) } & \multirow{2}{*}{$\begin{array}{c}\text { Variação média } \\
\text { anual }(\%)\end{array}$} \\
\hline & Fibra Longa & Fibra Curta & Total & \\
\hline 1970 & 278.156 & 385.907 & 664.063 & 17,05 \\
\hline 1971 & 292.142 & 429.398 & 721.500 & 8,65 \\
\hline 1972 & 308.636 & 589.704 & 898.340 & 24,51 \\
\hline 1973 & 329.828 & 641.859 & 971.687 & 8,16 \\
\hline 1974 & 379.169 & 750.357 & 1.129 .526 & 16,24 \\
\hline 1975 & 358.768 & 830.840 & 1.189 .608 & 5,32 \\
\hline 1976 & 450.502 & 803.282 & 1.253 .784 & 5,39 \\
\hline 1977 & 509.105 & 993.165 & 1.502 .270 & 19,82 \\
\hline 1978 & 539.512 & 1.274 .482 & 1.813 .994 & 20,75 \\
\hline 1979 & 606.982 & 1.840 .769 & 2.447 .751 & 34,94 \\
\hline 1980 & 755.572 & 2.117 .124 & 2.872 .696 & 17,36 \\
\hline 1981 & 742.006 & 2.053 .764 & 2.795 .790 & $(2,68)$ \\
\hline 1982 & 799.421 & 2.095.349 & 2.894 .770 & 3,54 \\
\hline 1983 & 891.731 & 2.166 .042 & 3.057 .773 & 5,63 \\
\hline 1984 & 973.643 & 2.426 .742 & 3.364 .385 & 10,03 \\
\hline 1985 & 1.058 .310 & 2.345 .154 & 3.403 .464 & 1,16 \\
\hline 1986 & 1.119 .768 & 2.435 .639 & 3.555 .407 & 4,46 \\
\hline 1987 & 1.164 .055 & 2.500 .406 & 3.664 .461 & 3,06 \\
\hline 1988 & 1.242 .618 & 2.550 .250 & 3.792 .868 & 3,50 \\
\hline 1989 & 1.226 .011 & 2.717 .868 & 3.943 .879 & 3,98 \\
\hline 1990 & 1.174 .456 & 2.740 .232 & 3.914 .688 & $(0,74)$ \\
\hline 1991 & 1.212 .464 & 3.134 .056 & 4.346 .520 & 11,03 \\
\hline 1992 & 1.262 .319 & 3.608 .248 & 4.870 .567 & 12,05 \\
\hline 1993 & 1.357 .412 & 3.652 .776 & 5.010 .188 & 2,86 \\
\hline 1994 & 1.363 .237 & 4.013 .034 & 5.376 .271 & 7,30 \\
\hline 1995 & 1.411 .505 & 4.031 .437 & 5.442 .942 & 1,24 \\
\hline 1996 & 1.345 .347 & 4.390 .831 & 5.736 .178 & 5,38 \\
\hline
\end{tabular}

Fonte: Associação Nacional dos Fabricantes de Papel e Celulose (1996) 
Tabela 4- Resultado econômico da atividade industrial brasileira de celulose e papel no ano de 1996

\begin{tabular}{lc}
\hline \multicolumn{1}{c}{ Atividade } & 1996 \\
\hline Produção total de celulose (milhões de toneladas) & 5,7 \\
Produção total de papel em milhões de toneladas & 6,2 \\
Faturamento global do setor em US\$ bilhões & 7,5 \\
Valor das exportações de celulose (US\$ milhões) & 999 \\
Valor das exportações de papel em US\$ milhões & 935 \\
Valor dos impostos recolhidos em US\$ milhões & 932 \\
Valor dos salários pagos em US\$ milhões & 827 \\
\hline Fonte : Associação Nacional dos Fabricantes de Papel e Celulose (1996)
\end{tabular}

No plano interno, continua o avanço da modernização do setor tanto técnica quanto administrativa. As indústrias conjuntamente e orientadas pela Associação Nacional dos Fabricantes de Papel e Celulose (ANFPC), formularam um plano de investimento denominado "A política de desenvolvimento do complexo de celulose e papel para 1995-2005". Para este intervalo, as projeções dão conta da necessidade de quase dobrar a produção brasileira nos próximos dez anos, estimando-se investimentos globais da ordem de 13 bilhões de dólares neste período.

Bracco (1996) analisando um estudo do BNDES, alerta para as dimensões do déficit de madeira para a próxima década, aonde a disponibilidade de fibras irá como conseqüência requerer uma área plantada maior. A demanda por celulose no ano de 2005 é estimada em 9,5 milhões de toneladas-ano no mercado interno e 2,6 milhões de toneladas-ano para garantir o espaço conquistado no mercado externo, gerando uma demanda adicional de 3,87 milhões de toneladas de madeira, o que significa cerca de 600 mil hectares a mais de área plantada (74\% para a indústria de celulose e papel).

O estado de São Paulo que apresenta a maior área reflorestada do país (21\%) com o eucalipto ocupando $86,38 \%$ desta área, teria como reflexo desta demanda adicional, uma perspectiva de crescimento da área de florestas plantadas em torno de 109 mil hectares ou cerca de 40 milhões de metros estéreos de madeira ( $1^{\circ}$ corte). Isto 
significa uma sobrecarga no uso da malha viária do estado com cerca de 800 mil viagens para transporte desta matéria prima, ou um acréscimo na demanda equivalente a de seis novas indústrias do porte das que compõem este estudo, em um período de nove anos.

A perspectiva considerando apenas os efeitos do segmento de celulose e papel, seria de no mínimo o dobro da pressão atual em termos de tráfego de carga de madeira nas rodovias paulistas para a primeira década do próximo século.

Tabela 5 - Volume anual de madeira efetivamente recebido no pátio das indústrias de celulose e papel (st)

\begin{tabular}{lrrrr}
\hline \multirow{2}{*}{ Gênero } & \multicolumn{4}{c}{ Anos } \\
\cline { 2 - 5 } & \multicolumn{1}{c}{1993} & \multicolumn{1}{c}{1994} & \multicolumn{1}{c}{1995} & \multicolumn{1}{c}{1996} \\
\hline Eucaliptos & $25.850 .365,0$ & $27.619 .432,0$ & $28.773 .158,0$ & $31.215 .599,0$ \\
Pinus & $14.489 .983,0$ & $12.384 .096,9$ & $14.097 .316,0$ & $14.047 .006,7$ \\
Outros & $2.700 .802,0$ & $2.259 .897,5$ & $2.028 .257,0$ & $1.600 .929,7$ \\
Total & $43.041 .150,0$ & $42.263 .426,5$ & $44.898 .731,0$ & $46.863 .535,4$ \\
\hline
\end{tabular}

Fonte: ANFPC (1996)

Pela Tabela 5 pode-se observar que o volume de madeira de eucalipto transportado apresenta uma tendência crescente. Como o estado de São Paulo responde por cerca de $30 \%$ de toda produção nacional de celulose, cerca de 14 milhões de st/cc de toras de madeira para celulose foram movimentados nas rodovias paulistas no ano de 1996, com 80\% deste volume transportado dentro de distâncias inferiores a 200 quilômetros (Associação Nacional dos Fabricantes de Papel e Celulose, 1996).

Algumas indústrias do setor de celulose, chegam a movimentar diariamente cerca de 135 caminhões na descarga para uma frota média de 250 caminhões, com uma freqüência de 1 a 1,5 viagem por dia em rotas com menos de 150 quilômetros, e de 4 a 5 viagens por semana em rotas de até 350 quilômetros (Stape et al.,1993).

Uma das indústrias envolvida neste estudo, consome 2.800.000 st/ano de madeira no processo de produção de celulose, com distância média de transporte em 
torno de 204 quilômetros, consumindo em média 9 horas e 30 minutos por viagem no transporte principal, que em um turno de 24 horas permite até duas viagens por dia transportando 50 st por viagem (Equipe, 1992). 


\section{O MERCADO DE CHAPAS DE COMPOSIÇÃO}

A perspectiva de mercado para o segmento de chapas de composição é considerada pela Associação Brasileira dos Produtores de Madeira (ABPM) em franca ascensão, decorrente da escassez evidente de madeira sólida. A produção de chapas de composição teve início no Brasil na década de 50 e já em 1993 havia seis indústrias em atividade com capacidade instalada de 2 milhões de metros cúbicos. Duas delas, situadas na região Sul do país com capacidade nominal de produção de 1,471 milhões de metros cúbicos anuais, respondem por $71,5 \%$ da produção nacional, consumindo ambas um total de 4 milhões de metros estéreos de madeira por ano.

Tabela 6. Taxa estimada de crescimento do consumo mundial de madeira industrial no período de 1985 a 2005.

\begin{tabular}{lc}
\hline Compensados de coníferas & $45 \%$ \\
Chapas de composição & $295 \%$ \\
Compensados de folhosas & $45 \%$ \\
Madeira serrada & $10 \%$ \\
\hline
\end{tabular}

Fonte: ABPM (1995)

Pela Tabela 6 pode-se afirmar que a tendência é de que o mercado de chapas de composição, além de demonstrar ser o mais promissor, praticamente triplique de tamanho na virada do próximo século, acarretando todas as consequiências de um superaquecimento na demanda por matéria-prima madeira, de características inelástica. Isto significa uma necessidade de ampliação da área plantada (Tabela 7), com acréscimo 
no volume de operações de abastecimento industrial, o que implica em última análise maior intensidade de uso da rede viária.

Tabela 7. Base florestal necessária para suprir o mercado brasileiro de chapas de composição e celulose.

\begin{tabular}{lcccc}
\hline Ano & Chapas de composição & Taxa (\%) & Celulose & Taxa (\%) \\
\hline 1986 & 1.505 & - & 290 & - \\
1990 & 1.740 & 15,6 & 333 & 14,8 \\
2000 & 3.105 & 78 & 563 & 69 \\
2010 & 5.525 & 78 & 697 & 23 \\
\hline
\end{tabular}

Em 1.000 hectares

Fonte: Dornelles (1998)

A Organização das Nações Unidas para a Agricultura e Alimentação (FAO) prevê que o consumo mundial de painéis a base de madeira crescerá dos 121 milhões de metros cúbicos de 1991 para 313 milhões de metros cúbicos no ano 2010, ou seja, quase que triplicando a demanda para chapas de composição dentro deste período (Gresham, 1995).

Villela Filho (1992), analisando as perspectivas da economia florestal para o próximo século, prevê um crescimento da demanda mundial de madeira para painéis da ordem de $2 \%$ ao ano, algo em torno de 70 milhões de metros cúbicos anuais.

Neves (1998) prevê um crescimento acima de 10\% para a indústria de chapas de composição até o ano 2005, alavancado tanto pelo mercado doméstico que está reagindo positivamente à estabilização econômica do país quanto pelo potencial de geração de divisas na exportação.

A indústria em 1996 bateu um recorde de produção totalizando 3,4 milhões de metros cúbicos, o que significa um aumento de $70 \%$ em relação ao início da década. A liderança desta produção é das indústrias Duratex e Eucatex, apontadas como as duas maiores fabricantes de chapas de composição do país. Para o ano 2001, projeta-se uma produção de 5,5 milhões de metros cúbicos, ou seja, um crescimento de mercado da ordem de 175\% sobre 1990 (Associação Brasileira de Produtores de Madeira, 1997). 
No ano de 1995, ambas as indústrias com receita operacional bruta de US\$ 389,8 e US $\$ 126,9$ milhões respectivamente situaram-se entre as vinte maiores empresas dentro de um setor da economia ainda mais competitivo, o da construção civil, considerado prioritário na política de combate ao desemprego pelo atual governo (Exame, 1996).

O estado de São Paulo no ano de 1996 respondeu por 41,3\% do mercado doméstico de chapas de composição, cujo volume total girou em torno de 1.210 .000 metros cúbicos. Até o ano 2000, o setor tem planos de investimentos de US $\$ 775$ milhões em novas plantas industriais no país com capacidades instaladas adicionais de 2.430.000 metros cúbicos-ano, totalizando para o setor uma capacidade instalada de produção de 3.640.000 metros cúbicos-ano (Neves, 1998). 


\section{O CUSTO DE TRANSPORTE NO ABASTECIMENTO DE MADEIRA}

O problema de administrar o abastecimento de madeira das fábricas tem sido equacionado e estudado de diferentes maneiras. Dempster (1989) sugere a ponderação sobre a questão básica administrativa "onde se localiza a matéria-prima", uma vez que a distribuição espacial da madeira tem sido reconhecida e crescido de importância no planejamento geral da indústria.

Na opinião de Worrel (1959), o transporte é um importante custo a ser considerado no processamento de produtos madeireiros. A tendência é que as indústrias procurem se localizar próximo dos seus consumidores, caso os custos de transporte do produto final sejam maiores que os custos de transporte da matéria-prima madeira. O ideal é que na definição da localização geográfica de uma indústria do setor florestal, o somatório dos custos de transporte da madeira e do produto final seja minimizado. O caso padrão geral de localização das indústrias florestais é que não são orientadas no sentido do consumidor do produto final, uma vez que o processamento industrial arca com as perdas existentes em termos de peso e/ou volume da madeira.

Hederstrom (1975) também faz referências à importância de se considerar essas perdas em se tratando de produtos florestais. Elas ocorrem devido às diferenças que existem em termos de volume, peso e forma entre as características da matériaprima madeira antes do processo de produção (toras) e as características do produto final processado. Em termos volumétricos, o processamento da madeira pode gerar desperdícios que variam de $10 \%$ a $80 \%$ do volume inicial da matéria-prima. Em termos de peso, a matéria-prima que entra no processo tem um teor de umidade que varia de $50 \%$ a $150 \%$ do peso seco, enquanto os produtos processados saem com umidade variando de $8 \%$ a $20 \%$. No que diz respeito à forma, a matéria-prima madeira é redonda 
e cônica, gerando espaços vazios no empilhamento na carroceria do caminhão, enquanto que os produtos processados geralmente têm dimensões com ângulos retos, praticamente inexistindo espaços vazios no acondicionamento da carga.

A observação acima quanto às diferenças em volume, peso e forma entre a matéria-prima madeira e os produtos finais no acondicionamento da carga, juntamente com a característica predominante de baixo valor unitário da madeira ( $\mathrm{R} \$ \mathrm{st})$, explicam a elevada participação dos custos do transporte principal no custo do produto final.

No setor florestal existem dois tipos principais de transporte da matéria-prima madeira. O primeiro, em ordem de ocorrência, é conhecido como transporte primário ou extração, que se processa dentro do talhão e que é efetuado por equipamento específico. O transporte primário disponibiliza a madeira em um pátio intermediário ou na margem da estrada dentro da fazenda, de maneira a permitir o acesso e a carga dos caminhões que farão o segundo tipo de transporte. Este segundo transporte, denominado transporte principal (alvo deste estudo), vai desde o pátio intermediário dentro da fazenda até o pátio de estocagem no recinto da fábrica.

A pouca importância dada ao custo do transporte principal no Canadá é lembrada por Douglas (1988). Este autor destaca que, apesar da elevada participação do setor madeireiro na economia do país, ele não é tratado com a devida importância dentro dos custos totais. Entretanto, esta terça parte do custo da madeira posta fábrica é de aproximadamente 1,8 bilhão de dólares canadenses por ano, devendo ser olhada com mais cuidado e atenção uma vez que qualquer alteração nesta parte dos custos refletirá de maneira significativa nos custos finais de produção.

Observação semelhante é feita por Hauer (1992) em trabalho de pesquisa desenvolvido na província de Ontário, também no Canadá, onde ele questiona o modelo utilizado pelo governo para análise da sustentabilidade das florestas da região. A principal questão levantada por ele diz respeito à não consideração da variável distância de transporte pelo modelo adotado e à necessidade de maiores detalhamentos no que se refere à localização dos mercados consumidores e de suas respectivas áreas florestais de abastecimento. Apesar de reconhecida a importância tanto pelo governo como pela 
iniciativa privada, muito pouco tem sido feito para a melhoria das técnicas de planejamento atualmente utilizadas.

Segundo Silversides (1976) a distância governa o custo de transporte, poìs determina o volume de madeira que pode ser transportado por turno ou dia de trabalho, por unidade de transporte (t./caminhão/turno ou dia). Quanto mais extenso o trajeto, maior será o custo por unidade de volume transportado. O custo por tonelada por quilômetro $(\mathrm{R} \$ / \mathrm{t} . / \mathrm{Km})$ pode ser menor em distâncias maiores, uma vez que o veículo de transporte terá proporcionalmente um tempo de transporte produtivo (ou efetivo) maior do que nas curtas distâncias devido à menor freqüência dos tempos de carga, de descarga, espera em filas e demoras.

Pela Figura 2 observa-se que as indústrias de celulose e de chapas de composição abordadas neste estudo encontram-se geograficamente concentradas, proporcionando um uso desigual da rede de rodovias do estado de São Paulo. As fábricas e os povoamentos se encontram instalados notadamente na região leste do estado, demostrando, por ocasião do planejamento uma preocupação maior com o transporte do produto final do que com o transporte da matéria-prima madeira.

Com o desenvolvimento da economia, crescimento e sofisticação dos mercados e com a evolução técnico-industrial aliados à ampliação e melhoria da malha viária, os empresários foram levados a optar por terras mais distantes para instalação de povoamentos e novas plantas industriais. Este procedimento, em consonância com Worrel (1959), demonstra uma maior preocupação com o custo de transporte da matéria-prima madeira em relação ao transporte do produto final.

Quanto à participação do custo do transporte principal no custo final do produto, Ribeiro (1998), Costa Filho et al. (1980), Ramirez (1979) e Fahraeus (1974) apresentam para a celulose resultados com média aproximada de $10 \%$, variando de $6 \%$ a $21 \%$ em função da distância a ser percorrida na rota que une a fábrica ao povoamento florestal, e de $12 \%$ para produtos de serraria no caso de madeira de mata nativa. 


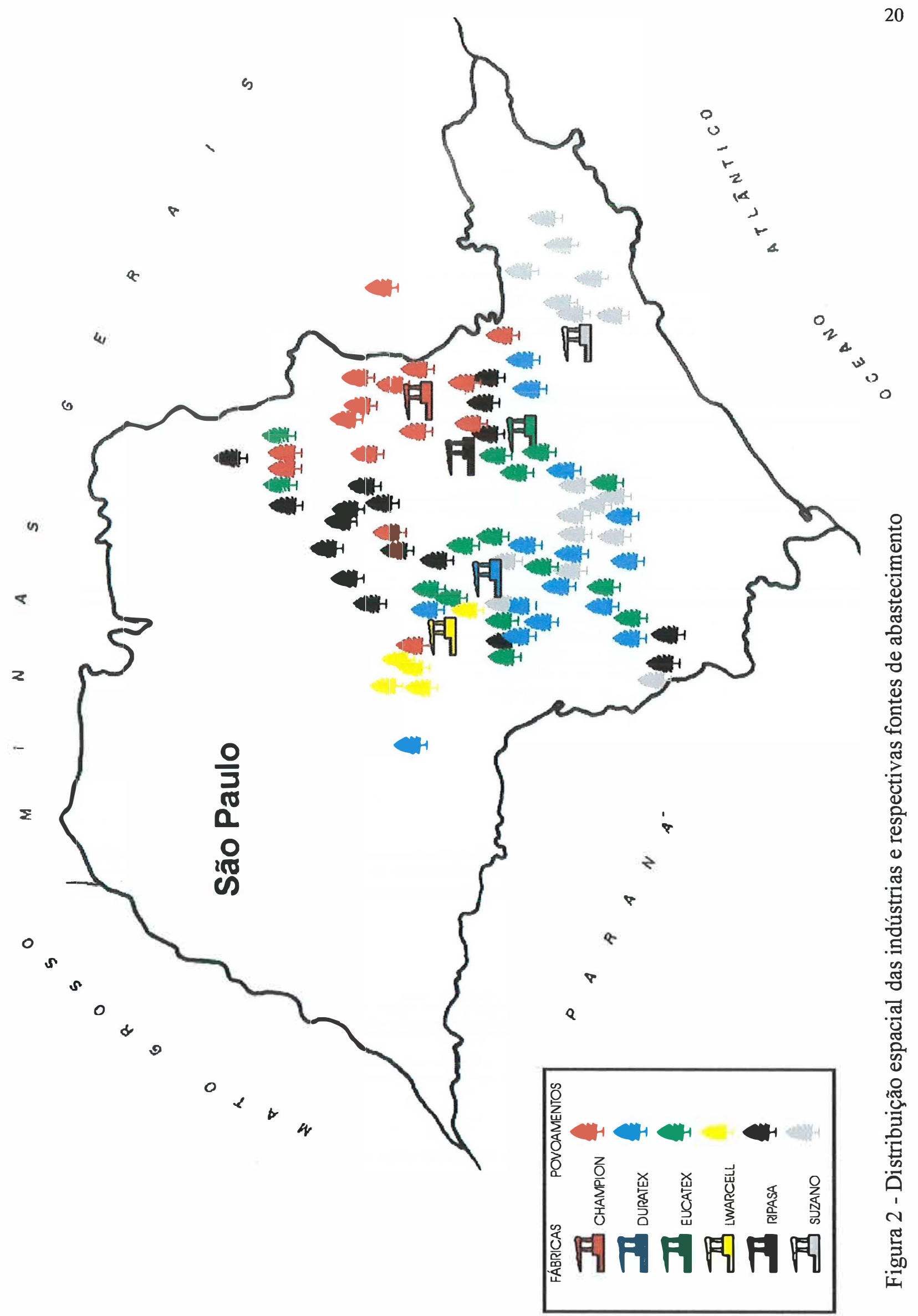


Berger (1975) mencionando Colombelli Filho, afirma que de $25 \%$ a $55 \%$ dos custos da madeira de eucalipto posto fábrica são devidos ao custo de transporte, que em sua quase totalidade é rodoviário.

Martini \& Leite (1988) trabalhando no estado de São Paulo, confirmam a significância do transporte no custo da madeira e conseqüentemente no produto final da indústria. O transporte representa de $40 \%$ a $50 \%$ do custo da madeira posta fábrica, variando diretamente com o raio de transporte. Consideram ainda a operação de abastecimento e seu planejamento como pontos cruciais para a manutenção da competitividade da indústria e da própria viabilidade econômica da produção de madeira.

Seixas e Widmer (1993) trabalhando com transporte principal no estado de São Paulo, afirmam que tal custo representa para algumas empresas de $38 \%$ a $66 \%$ do custo final de aquisição posto fábrica.

Mais da metade do custo total do setor florestal responsável pelo abastecimento industrial no Canadá é referente a custos de transporte. Segundo Douglas (1988), o custo estimado da madeira entregue nas indústrias do Canadá pode ser dividido em:

- Manejo de florestas, administração e planejamento com 35\%;

- Extração com 35\%;

- Transporte, estradas e manutenção com 30\%.

Hakkila et al. (1992) desenvolveram trabalho abordando a questão da mecanização no setor florestal comparando o Brasil com a Finlândia e chegaram a valores também bastante semelhantes aos já mencionados. Pela Tabela 8, os custos de transporte no caso do Brasil representam 44,54\% do custo total de exploração e no caso da Finlândia, 38,5\%.

Burger \& Jamnick (1995) apresentam duas estimativas de participação dos custos de transporte nos custos das indústrias madeireiras do Canadá. Uma, feita em 1983, considera que a colheita e o transporte da madeira respondem por $55 \%$ dos custos totais do manejo florestal. Outra, feita em 1991 para uma fábrica de celulose, aponta que os custos da matéria-prima madeira constituem de $30 \%$ a $40 \%$ do custo da madeira posta fábrica. 
Tabela 8. Custo médio da exploração de madeira para celulose e papel.

\begin{tabular}{lcc}
\hline Operação & Brasil $\left(\mathrm{US} \$ / \mathrm{m}^{3}\right)$ & Finlândia $\left(\mathrm{US} \$ \mathrm{~m}^{3}\right)$ \\
\hline Corte & 3,04 & 6,06 \\
Extração & 2,71 & 4,71 \\
Transporte $(90 \mathrm{~km})$ & 5,59 & 7,40 \\
Outros & 1,21 & 1,05 \\
Total & 12,55 & 19,22 \\
\hline
\end{tabular}

Fonte: Hakkila et al. (1992)

Apesar dos avanços observados no desenvolvimento de máquinas, equipamentos, técnicas de planejamento e controle para execução das operações de transporte de madeira, países do primeiro mundo como a Suécia confirmam a importância do custo do transporte principal para suas indústrias madeireiras, sendo que esta despesa responde, segundo Carlsson \& Arvidsson (1998), por 10\% a 15\% do custo da madeira posta fábrica. 


\section{A UTILIZAÇÃO DE PROGRAMAÇÃO LINEAR NA ANÁllSE DO TRANSPORTE PRINCIPAL DE MADEIRA}

O ponto básico em uma tomada de decisão na área de produção em economia florestal é encontrar o uso mais eficiente dos recursos produtivos escassos. Esta eficiência tem que estar relacionada aos objetivos do proprietário dos recursos e aos objetivos das indústrias que os utilizam. Uma produção é mais eficiente se resultar em um máximo de produto para uma dada quantidade de recursos ou em um mínimo de quantidade de recursos para um dado nível de produção. Para o caso específico deste trabalho, custos, toneladas transportadas e quilômetros percorridos são algumas das unidades de medida utilizadas para expressar eficiências.

A Pesquisa Operacional compreende o desenvolvimento de instrumental de apoio a este processo de tomada de decisão com relação aos recursos escassos. A programação linear é um dos métodos mais utilizados, com o objetivo de orientar as indústrias individualmente e facilitar o uso mais eficiente de seus recursos.

O problema do fluxo rodoviário de transporte de toras curtas de eucalipto no estado de São Paulo pode ser modelado utilizando-se uma formulação baseada em técnicas de programação linear. Esta técnica é de aplicação generalizada em diversos estudos, mas com poucas referências quanto à sua utilização na análise de problemas de transporte principal no setor florestal.

O poder da técnica de programação matemática reside no fato de que enquanto ela formaliza e processa o problema resolvendo uma situação complexa, também conserva as condições essenciais da situação real. 
Vários aspectos são apontados por diferentes autores como razões para a existência de uma grande barreira à adoção e maior difusão do uso de software de otimização no planejamento por parte de empresas do setor florestal.

Duran et al. (1985) consideram a falta de experiência em modelagem, a grande quantidade de dados requeridos pelos modelos, a baixa qualidade e não disponibilidade dos mesmos como os principais componentes desta barreira. Considerando-se o nível de desenvolvimento da informática para a época em que os autores escreveram o trabalho, as dificuldades de processamento de dados deveriam também constar como um dos principais componentes dessa barreira.

Wagner (1986) faz uma estimativa de que um terço dos esforços requeridos para a aplicação de modelos de otimização linear está justamente na atividade de formulação do modelo. Tecendo comentários sobre a importância industrial de tais modelos, o autor menciona explicitamente as companhias petrolíferas, que têm desenvolvido modelos de otimização linear para, entre outros fins, determinar a lucratividade bruta em trocar óleo cru de sua propriedade por óleo cru de propriedade de outra companhia.

Oliveira (1993) considera o enorme desenvolvimento experimentado pelo setor de informática como passo decisivo para a absorção e difusão da Pesquisa Operacional pelo setor florestal no Brasil. Acrescente-se a esta observação, a importância da quebra de reserva de mercado no setor de informática, promovendo um avanço no suprimento de software e hardware.

A falta de conhecimento detalhado do método por parte da direção das empresas e do pessoal técnico (treinamento), somada à inexperiência e formação profissional dos pesquisadores do setor florestal são apontados por Caixeta Filho (1993) como algumas das dificuldades para a não adoção de tais técnicas de modo mais amplo pelo setor florestal brasileiro.

Chinneck \& Moll (1995) estudando o processamento de modelos para manejo de florestas na Inglaterra, acrescentam a esta lista de barreiras a forma de apresentação matemática dos modelos de otimização. Surge, então, um problema de comunicação e 
entendimento entre os profissionais de planejamento e os profissionais de execução, como sendo mais um fato para explicar a existência desta barreira. Ainda segundo Chinneck \& Moll (1995), essa forma matemática dos modelos pode ser bastante compreensível para pesquisadores de sistemas operacionais e para acadêmicos, porém é praticamente intelegível para os trabalhadores ou profissionais de execução.

Hartstela (1997) analisando a adoção dos sistemas de suporte a tomadas de decisão no abastecimento de madeira para indústrias na Finlândia, ratifica as observações feitas por outros autores quando afirma que, apesar da técnica já ser utilizada pelas grandes empresas desde o início da década de 90 , essa prática não é difundida entre as empresas de menor porte.

\subsection{Histórico}

A tendência observada nos trabalhos consultados mostra que $o$ desenvolvimento de modelos matemáticos em programação linear aplicada ao setor florestal se divide nitidamente em dois ramos de pesquisas. Um deles é voltado para o manejo integrado de florestas e o outro, para questões relativas à colheita e transporte de madeira.

Price et al. (1993) atestam que o método desde o início mostrou-se bastante útil em situações referentes à produção. Sua utilização começou por volta de 1959 com Theiler usando dados hipotéticos para questões relativas ao abastecimento de madeira. Ainda segundo Price et al., neste mesmo sentido, desenvolveram trabalhos, Leak (1964), Loucks (1964), Kidd, Thompson e Hoepner (1966), McConnen, Amidon e Navon (1966), Nautiyal e Pearse (1967), Navon e McConnen (1967), Navon (1967), Norman e Curlin (1968) e Clutter e Bethune (1969), todos relacionados à colheita e transporte florestal.

Chappelle (1977) faz um levantamento histórico e observa que desde 1950 a programação linear tem ganhado terreno como método de alocação de recursos em manejo e planejamento florestal. Martin \& Sendak (1973), citados por Chappelle 
(1977), observam que o número de publicações nos Estados Unidos utilizando programação linear em florestas no intervalo de 1950 (primeira vez) até 1970 foi de 105 trabalhos. Aproximadamente 51\% destes trabalhos referem-se à alocação da commodity madeira e de seus produtos para o mercado consumidor (transportes primário e secundário), 47\% refere-se à alocação ótima de pontos de produção e distribuição e $4 \%$ são orientados para questões de otimização de fluxos inter-regionais.

Dykstra (1984) referindo-se à esta listagem feita por Martin \& Sendak (1973), considera que no mínimo a mesma já triplicou de tamanho, com mais de 305 trabalhos publicados em 11 anos. Dykstra (1984) menciona ainda as colaborações de Little \& Wooten (1972) em trabalho de otimização de pátios de estoque e Newnham (1975) no planejamento de exploração madeireira.

Três estudos na década de 80 foram desenvolvidos no Canadá enfocando especificamente a questão da distribuição ou transporte. Churcher (1981) usou a programação linear para alocar madeira entre serrarias na província de New Brunswick. O estudo envolveu um período de 10 anos e 90.000 hectares para suprir 12 grupos de serrarias. Walker \& Preiss (1988), usando o mesmo recurso matemático, ajudou a planejar a colheita e o transporte para um período de cinco anos para cinco serrarias no nordeste da província de Ontário. Wigthman \& Jordan (1990) também usaram programação linear para criar um modelo de distribuição anual de madeira para nove serrarias na província de New Brunswick (Burger \& Jamnick, 1995).

Os primeiros estudos sobre as técnicas de programação matemática voltadas especificamente para as operações de transporte de madeira surgem em congressos, conferências e simpósios na primeira metade da década de 60. Constituem-se basicamente de estudos e desenvolvimentos teóricos de modelos, com algumas proposições sem aplicações efetivas, utilizando dados fictícios. Os primeiros estudos de caso com dados empíricos aparecem somente na segunda metade da década de 60 .

São três os principais pólos responsáveis por estes primeiros avanços no desenvolvimento de modelos matemáticos de programação linear, aplicados ao transporte de madeira. Os países de língua inglesa Canadá, Estados Unidos e Nova 
Zelândia constituem um dos blocos. Os países escandinavos preocupados em racionalizar a produção de grandes empresas exportadoras, principalmente Finlândia e Suécia, um segundo bloco. Os países de economia planejada (Croácia, Hungria, Polônia, Rússia e Checoslováquia), membros da antiga União Soviética, constituem um terceiro bloco.

Na primeira metade da década de 70, os trabalhos de Barr (1970), Korinek (1972) e Abel (1973) mostram que a maior preocupação na época era com o domínio da técnica recém adotada e com o aprimoramento dos métodos através de estudos usando dados fictícios e simulações. Em uma segunda etapa, desenvolveram estudos demonstrando os reflexos da otimização do transporte na organização da indústria e na economia como um todo.

$\mathrm{Na}$ segunda metade da década de 70 , respondendo aos interesses de grandes indústrias no planejamento do transporte de madeira, aparecem os primeiros estudos como os de Gregersen \& Nylinder (1979), todos voltados para o desenvolvimento de modelos aplicados para situações reais utilizando dados empíricos.

Roitto (1975) discute teoricamente os problemas econômicos relativos às otimizações no setor florestal para a Finlândia, onde há forte competição entre as indústrias madeireiras. Ao sugerir que o ótimo na alocação da matéria-prima madeira pode não ser aquele que minimiza o custo de transporte, mas sim aquele que maximiza a diferença entre os preços pagos no pátio da indústria (destino) e os custos de colheita (origem) somados aos custos de transporte desta madeira, o autor demonstra a riqueza de combinações e informações que se pode conseguir no processo de modelagem.

Além disso, comprova também o porque da ênfase de vários autores ao item "experiência em modelagem" para o sucesso na utilização prática da técnica. A primeira abordagem (minimização do custo de transporte) fornece uma perspectiva microeconômica com enfoque nas questões administrativas pertinentes ao universo individual das indústrias. A segunda abordagem (maximização da diferença) amplia a perspectiva para questões macroeconômicas permitindo enfoques regionais como, por exemplo, análise e formação de preços. 
A década de 80 inicia com estudos mais apurados dos detalhes técnicos. O objetivo é identificar os potenciais de aplicação e os limites dos modelos matemáticos de programação linear aplicados na otimização do transporte de madeira.

Trampler \& Wdowiak (1983) examinam a maneira como se organizam as relações entre os povoamentos florestais e as indústrias da madeira, tomando como referência os custos de transporte da matéria-prima, o que termina por influenciar na localização das serrarias (objeto do estudo) e no seu abastecimento.

Das relações entre povoamentos e indústrias florestais, permeadas pela necessidade do transporte que liga a oferta de madeira com a demanda, surgem diversas possibilidades teóricas de otimização utilizando programação linear. Todas as possibilidades identificadas por diversos autores ao longo da década consideram o custo mínimo de transporte como referencial nas definições dos modelos.

Primeiramente, temos uma situação como o cenário do trabalho de Rose et al. (1984), em que os custos de transporte da matéria-prima definem o melhor local para a instalação de uma serraria. Neste caso já se tem definidos a localização e características dos povoamentos fornecedores, as dimensões e os tipos de caminhão que compõem a frota que fará o transporte, faltando definir o local em que se construirá a indústria de transformação.

Uma segunda possibilidade é abordada nos trabalhos de McGuigan (1984) e Miyata et al. (1986), que desenvolvem modelos de otimização em programação linear, com o propósito de definir quais os melhores locais de colheita da madeira para o abastecimento industrial (dentro de um elenco), com base no menor custo de transporte. Neste caso, já se encontra previamente definidos a localização da indústria e o dimensionamento da frota que fará o transporte, faltando definir o local de onde se fará a retirada da madeira, respeitando-se as capacidades de oferta e de demanda.

Hadi et al. (1988) apresentam uma nova perspectiva para a técnica ao considerarem os reflexos da otimização de modelos de transporte na rentabilidade do sistema em que a indústria madeireira se insere, e não mais apenas sobre o comportamento da indústria individualmente. 
Uma outra possibilidade aparece em Korpilahti (1989), trabalhando na Finlândia. Ele desenvolveu um sistema para microcomputadores utilizando planilhas de cálculo e programação linear com o propósito de analisar a taxa de eficiência no uso de caminhões no transporte principal de madeira. E’ um cenário onde só falta caracterizar e dimensionar a frota para o abastecimento, uma vez que já se têm definidos a localização geográfica da indústria e dos povoamentos de onde será retirada a madeira.

Os trabalhos desenvolvidos na década de 90 confirmam as perspectivas de desenvolvimento e aplicação dos modelos de transporte no setor florestal. Tem-se como exemplos, trabalhos em viveiros para o abastecimento de mudas como os de Rajive et al. (1992), estudos do comportamento da oferta e demanda de madeira industrial como os de Berg \& Larsson (1994) e Fukuda et al. (1991), estudos da viabilidade técnica e econômica de equipamentos em função do fluxo de transporte como os desenvolvidos por Oijala et al. (1993).

Na segunda metade da década, surgem trabalhos que dão suporte para que a programação linear continue tendo seu espaço e sendo bastante utilizada em Pesquisa Operacional, apesar da evolução e surgimento de novas técnicas.

Brack \& Marshall (1996) e Palander (1997) reafirmam a condição da programação linear como técnica de suporte para tomada de decisão, bastante apropriada e superior às demais, para o caso de operações ligadas ao fluxo de madeira. Martell et al. (1998) consideram 1996 um ano especial, de intensos esforços e ênfase nos trabalhos produzidos no sentido de incorporar as questões ambientais e ecológicas aos modelos de programação linear do segmento florestal da economia.

A possibilidade de utilização da internet para coordenação do fluxo de transporte dentro e entre as empresas é levantada por Walter \& Carlsson (1998) que, com o apoio do Instituto de Pesquisas Florestais da Suécia, desenvolveu um "software" de otimização de rotas para microcomputadores. Carter et al. (1999) avançam neste sentido ao fazer uma revisão e fornecer endereços dos pesquisadores que já utilizam a internet para disponibilizar "software" de Sistemas de Informações Geográficas (GIS), 
alguns utilizando programação linear para solucionar modelos de transporte primário, aplicados em manejo de recursos naturais.

No Brasil, os trabalhos de Dias et al. (1984), Rodriguez (1986) e Rodriguez e Moreira (1989) definem uma vertente de pesquisa na utilização de programação linear aplicada ao setor florestal, desenvolvendo sistemas de planejamento para manejo integrado de florestas. A outra vertente voltada para a utilização de programação linear especificamente para colheita e transporte florestal iniciou-se na década de 70 com trabalhos de Berger (1975).

Pereira \& Paula Júnior (1982 e 1980) utilizaram programação linear aplicada à produção e ao transporte de carvão vegetal no Vale do Jequitinhonha, em Minas Gerais, adequando rotas e tipos de caminhões disponíveis com base no custo mínimo de transporte.

Seixas \& Widmer (1993) utilizam programação linear para selecionar e dimensionar frotas de veículos para transporte principal de madeira e comentam também a quase inexistência de estudos voltados para este tipo de transporte. O objetivo nestes modelos é minimização do custo de se transportar a madeira a partir de fontes distintas até um destino único, determinando o tamanho da frota e tipo de veículos.

\subsection{Performance dos modelos de otimização aplicados ao transporte principal de madeira}

Caixeta Filho (1993) ressalta a importância da adoção de técnicas de Pesquisa Operacional no gerenciamento logístico do transporte, já que ganhos monetários da ordem de $1 \%$ ou $2 \%$ nos custos de transporte de madeira se mostram bastante significativos.

Bidzinska et al. (1985) aplicam um modelo de otimização desenvolvido para racionalizar o transporte e melhorar a eficiência na distribuição de produtos das indústrias madeireiras na Polônia. Os autores conseguem reduzir a distância média 
percorrida por metro cúbico de madeira posta fábrica $(\mathrm{Km} / \mathrm{m} 3)$, gerando um ganho de eficiência de $12 \%$ no processo de abastecimento.

Carlsson \& Arvidsson (1998) fazem referências diretas a ganhos anuais da ordem de 3,6\% para o setor florestal da Suécia devido à otimização de rotas com redução no custo anual de transporte principal de madeira. Este percentual eqüivale a uma redução de US\$12,5 milhões anuais para a economia do país e a uma diminuição de $6 \%$ no tamanho da frota nacional envolvida em transporte de madeira. $\mathrm{O}$ desdobramento destes ganhos em termos ambientais se dá sob a forma de menos 20 milhões de quilômetros anualmente percorridos pelos caminhões, com uma redução na queima de óleo diesel da ordem de 6,5 milhões de litros anuais e menos 5\% na emissão de gases poluentes da exaustão dos motores.

Weintraub et al. (1995), mencionados por Martell et al. (1998), desenvolvem modelos para tomada de decisão especificamente para o transporte principal de madeira para indústria no Chile, conseguindo melhorar a eficiência do transporte com ganhos variando de $15 \%$ a $25 \%$, medidos em termos de necessidade de caminhões, custos operacionais e horas de trabalho.

Gabarró et al. (1999) desenvolveram um dos poucos sistemas informatizados existentes usando programação linear para tomada de decisão na operação de colheita de madeira. A principal proposta é maximizar o lucro líquido, atendendo às exigências de demanda e definindo máquinas e equipamentos a serem utilizados. Os resultados da aplicação dos modelos mostram ganhos de eficiência da ordem de $5 \%$ a $8 \%$ da renda líquida da empresa quando comparados com o método tradicionalmente usado.

Outros segmentos da economia têm lançado mão da mesma técnica com os mesmos objetivos, pois as empresas precisam manter uma performance competitiva no seu desempenho com uma eficiente alocação de seus recursos produtivos. Esta busca por parte das empresas e da economia como um todo é que mantém e sustenta o interesse pela pesquisa em planejamento logístico. O transporte de derivados do petróleo e o transporte de produtos congelados são dois segmentos freqüentemente mencionados nas pesquisas em planejamento logístico. 
Em um dos trabalhos mais recentes, Ross (2000), desenvolve um modelo de otimização com base na maximização de lucros para o transporte e distribuição de derivados na indústria petrolífera do estado do Texas (EUA). A pergunta que o autor se faz é: qual a extensão da influência do modelo na atual rede de distribuição de derivados? A resposta vem com a comparação entre os resultados do modelo com o transporte realizado pela empresa, apresentando ganhos de eficiência da ordem de $13 \%$ na distribuição de derivados e de 3,6\% no lucro líquido do sistema de distribuição. 


\section{MATERIAL E MÉTODOS}

O trabalho analisa e avalia o transporte da madeira produzida e consumida por um significativo grupo de empresas dentro do estado de São Paulo. O estudo envolveu quatro das 12 indústrias do segmento de celulose e papel existentes no estado e as duas únicas indústrias do segmento de chapas de composição no Brasil, com áreas de plantio localizadas em 93 municípios paulistas (Tabela 9).

Segundo Ondro et al. (1995) e a Associação Nacional dos Fabricantes de Papel e Celulose (1996), dentre as quatro indústrias de celulose abordadas neste trabalho, três são consideradas as mais avançadas em nível de tecnologia adotada no país e as maiores em termos de capacidade instalada. As quatro juntas respondem por $20 \%$ da produção nacional e por $63 \%$ da produção estadual, ocupando 55\% da área plantada com eucalipto no estado. As duas indústrias de chapas de composição localizadas no estado de São Paulo são detentoras de $70 \%$ e $30 \%$ do mercado nacional.

\subsection{Caracterização do fluxo de transporte de madeira realizado}

As informações levantadas para gerar os dados utilizados foram fornecidas pelas empresas, inclusive os fatores de transformação. Os povoamentos que no ano de 1996 forneceram madeira para as indústrias foram agrupados em fazendas ou origens, seguindo orientação das próprias indústrias e identificados pelos municípios a que pertencem, resultando em seis destinos e 32 origens. 
Tabela 9. Indústrias envolvidas no estudo e respectivos municípios de atuação.

\begin{tabular}{|c|c|c|c|c|c|}
\hline Champion & Ripasa & Eucatex & Suzano & Duratex & Lwarcel \\
\hline Aguaí & Abrasilienses & Angatuba & Alambari & Atibaia & A.St $t_{a}$ Bárb. \\
\hline Agudos & Araraquara & Anhenbi & Angatuba & Angatuba & Agudos \\
\hline Brotas & Analândia & Apiaí & Biritib.Mirim & Avaré & Arealva \\
\hline Casa Branca & Avaré & Avaré & Bertioga & A.St ${ }_{a}$. Bárb. & Avaí \\
\hline Campinas & Agudos & Botucatu & Bofete & Agudos & Bauru \\
\hline E.S.Pinhal & Altinópolis & Buri & Guararema & Buri & Borebi \\
\hline Estiva Gerbi & B.Esp.do Sul & Conchas & Itapetininga & Botucatu & Buritama \\
\hline Eng.Coelho & Bocaina & Elias Fausto & Itararé & Bofete & CabráliaPt $_{\mathrm{a}}$ \\
\hline Itapira & Brotas & Guareí & Itatinga & C. Bonito & Iaras \\
\hline Ipuiuna & Borebi & Itapeva & M.das Cruzes & Guareí & Itatinga \\
\hline Leme & Corumbataí & Itatinga & Pilar do sul & Itupeva & L.Paulista \\
\hline M.Guaçu & Campinas & Itu & Pardinho & Itapetininga & Piratininga \\
\hline M.Mirim & Descalvado & L.Paulista & Paraibuna & Itapeva & Pratânea \\
\hline M.A.doSul & Ibaté & Pilar do Sul & Suzano & Itatinga & S. Manoel \\
\hline Pedreira & Itirapina & Porto Feliz & S.L. Paraitinga & Jarinu & Ubarana \\
\hline Piracaia & Ipeúna & Salto & S.J.d Campos & Jundiaí & \\
\hline S.Simão & Iaras & S de Pirapora & Sarapuí & L. Paulista & \\
\hline S.R.Viterbo & Itararé & S.Manoel & S.de Pirapora & Paranapan. & \\
\hline S.A.Jardim & Itatiba & & S.Simão & Pederneiras & \\
\hline \multirow[t]{9}{*}{ S.J.B.Vista } & Limeira & & S.R.Viterbo & Salto & \\
\hline & L.Paulista & & S.M.Arcanjo & Sorocaba & \\
\hline & Monte Mór & & Salesópolis & S.M.Arcanjo & \\
\hline & Piratininga & & & & \\
\hline & Rib.Branco & & & & \\
\hline & São Carlos & & & & \\
\hline & São Pedro & & & & \\
\hline & São Simão & & & & \\
\hline & Vitoriana & & & & \\
\hline
\end{tabular}

Fonte: Indústrias

Total de 93 municípios dos quais 68 atuantes no ano de 1996 (73\%)

Indústrias:

- $\mathrm{CH}=$ Fábrica da Champion Papel e Celulose Ltda

- DU = Fábrica da Duratex S/A

- EU = Fábrica da Eucatex S/A

- LW = Fábrica da Lwarcel Celulose e Papel Ltda

- RI = Fábrica da Ripasa S/A

- SU = Fábrica da Cia. Suzano de Papel e Celulose 
Origens:

- $\mathrm{CH}_{\mathrm{i}} \quad(\mathrm{i}=1, \ldots .8)=$ Fazendas de propriedade da Champion

- $\mathrm{DU}_{\mathrm{i}}(\mathrm{i}=1, .3)$ = Fazendas de propriedade da Duratex

- $\mathrm{EU}_{\mathrm{i}}(\mathrm{i}=1, \ldots .6)=$ Fazendas de propriedade da Eucatex

- $\mathrm{LW}_{\mathrm{i}}(\mathrm{i}=1$ a 2$)=$ Fazendas de propriedade da Lwarcel

- $\mathrm{RI}_{\mathrm{i}} \quad(\mathrm{i}=1, \ldots .8)=$ Fazendas de propriedade da Ripasa

- $\mathrm{SU}_{\mathrm{i}}(\mathrm{i}=1, \ldots .5)=$ Fazendas de propriedade da Suzano

As fábricas, cada uma com a sua demanda anual, caracterizam-se como destinos da madeira. Suas fazendas produtoras de toras de eucalipto são caracterizadas como fontes de abastecimento ou origens da matéria-prima.

As seis indústrias e suas respectivas fazendas localizam-se em municípios situados na região leste do estado, entre os meridianos de número 46 e 48 . Para o ano em que se desenvolve o estudo, foram acionados 68 dos 93 municípios de atuação das indústrias, o que corresponde a $73 \%$ das opções de fontes de abastecimento disponíveis no ano de 1996. As seis indústrias juntas demandaram neste mesmo ano um total de 4.355.422 toneladas de toras curtas de eucalipto, supridas pelas 32 origens com quantidades ofertadas pré-estabelecidas no planejamento individual para o referido ano.

A opção pelo ano base de 1996 deve-se a entendimentos prévios efetuados no correr do ano de 1997 junto às indústrias participantes, quando então se definiu a proposta de trabalhar com valores já realizados. Convém ressaltar que para o objetivo principal deste trabalho, o número de indústrias participantes é suficiente e a questão do ano para o qual se faz a análise não é um ponto de relevância, uma vez que de um ano para o outro o que se altera são apenas os povoamentos dentro das mesmas fazendas fornecedoras. No curto prazo, o que pode ocorrer é a entrada ou saída de uma ou outra fazenda, muitas vezes situada dentro do mesmo município, modificando apenas as quantidades fornecidas por fazenda, alterando muito pouco no que diz respeito ao traçado de rotas dentro de uma mesma rede rodoviária. Permanecem como parte do problema as quantidades demandadas por indústria, a necessidade de transporte e as origens com as respectivas limitações de quantidades ofertadas. 
As visitas às seis indústrias participantes iniciaram-se em outubro de 1997 e terminaram em meados de 1998. Este levantamento constou do preenchimento de planilhas com formato previamente acordado entre os participantes e que atende tanto às demandas do trabalho quanto às exigências das administrações das indústrias envolvidas (Tabela 10). As informações foram complementadas com entrevistas realizadas em três das indústrias participantes. As entrevistas foram efetuadas de maneira aleatória nas portarias de recebimento de madeira, diretamente com os motoristas dos caminhões e funcionários das indústrias, procurando identificar e conhecer melhor as diferentes fases da operação do transporte principal, a burocracia envolvida, os procedimentos, máquinas e equipamentos utilizados, além de checar outras informações levantadas junto às indústrias.

\subsection{Caracterização dos modelos de otimização do fluxo de transporte de madeira}

Os parâmetros de análise foram definidos inicialmente com base na literatura consultada e nas propostas de avaliações contidas nos objetivos. As análises foram feitas observando-se o comportamento das indústrias identificadas de maneira individual e sob forma de um único "sistema" constituído das seis indústrias agregadas. Para se proceder as avaliações do transporte principal de madeira sob as óticas individual e agregada, foram consideradas comparativamente quatro situações ou cenários diferentes.

O primeiro deles, denominado "Realizado", é caracterizado em 6.1 e tomado como referência em todas as comparações feitas. Constitui-se de um levantamento detalhado da situação existente no transporte principal praticado no ano de 1996 e reflete as condições em que se processa o abastecimento das indústrias naquele ano. 


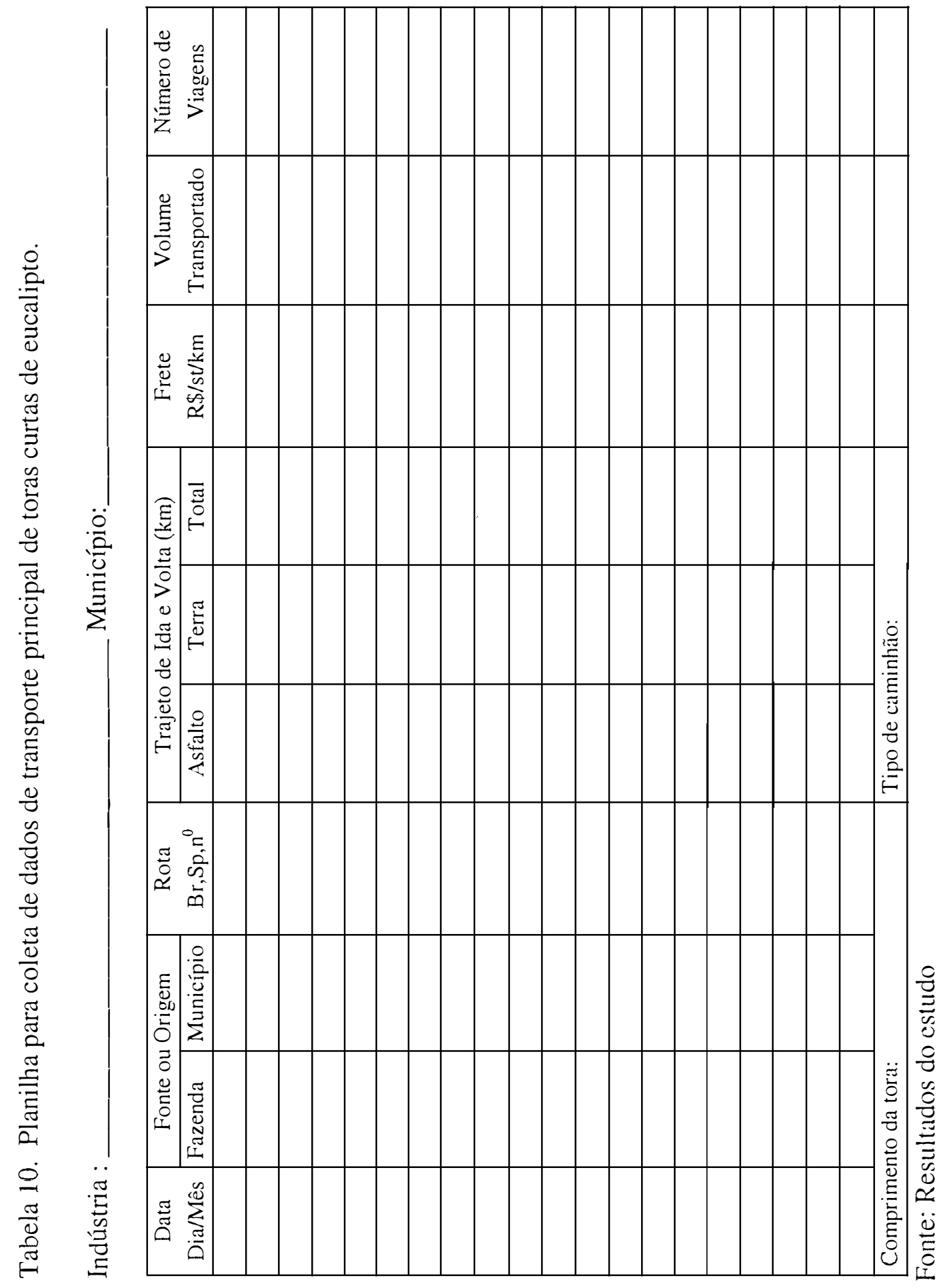


Os três outros cenários são definidos segundo os resultados das soluções ótimas de três modelos de transporte utilizando-se programação linear não-inteira, a saber: 1) Modelo de transporte com várias origens e vários destinos, sem definição do tipo de caminhão (Modelo I);

2) Modelo de transporte com várias origens e vários destinos, definindo o tipo de caminhão (Modelo II);

3) Modelo de transporte individualizado, com várias origens e um único destino, sem definição do tipo de caminhão (Modelo III).

\subsection{Modelo de transporte com várias origens e vários destinos, sem definição do tipo de caminhão (Modelo I)}

Trata-se do modelo de transporte aplicado a uma situação em que se têm seis unidades consumidoras (destinos) e 32 fontes de abastecimento (origens), sendo que para efeito do estudo quebra-se o vínculo de propriedade entre indústria e povoamento. Permite-se que o abastecimento das unidades industriais (destinos) seja feito por fazendas cujas propriedades não estão registradas em nome do grupo empresarial para onde se destina a madeira (Figura 3).

A matéria-prima "toras curtas de eucalipto" é considerada uma commodity, sendo inexistentes os vínculos ou quaisquer compromissos de abastecimento entre as indústrias e fazendas produtoras, ficando livres tanto para o fornecimento como para o recebimento. Esta pressuposição se estende para todos os três modelos.

A definição de quais são as fontes de abastecimento, bem como a definição das quantidades demandadas e ofertadas, constituem informações exógenas ao modelo, sendo previamente definidas no planejamento estratégico de atividades anuais das empresas. O volume total transportado de cada fazenda é considerado a oferta disponível da fazenda, limitada pelo planejamento da indústria à qual se encontra originalmente vinculada. 
Como proposta do modelo, deve-se satisfazer à demanda anual de madeira de cada indústria. As rotas são consideradas disponíveis e acessíveis durante todo o período do ano sem nenhuma restrição técnica para tráfego dos caminhões envolvidos no trabalho.

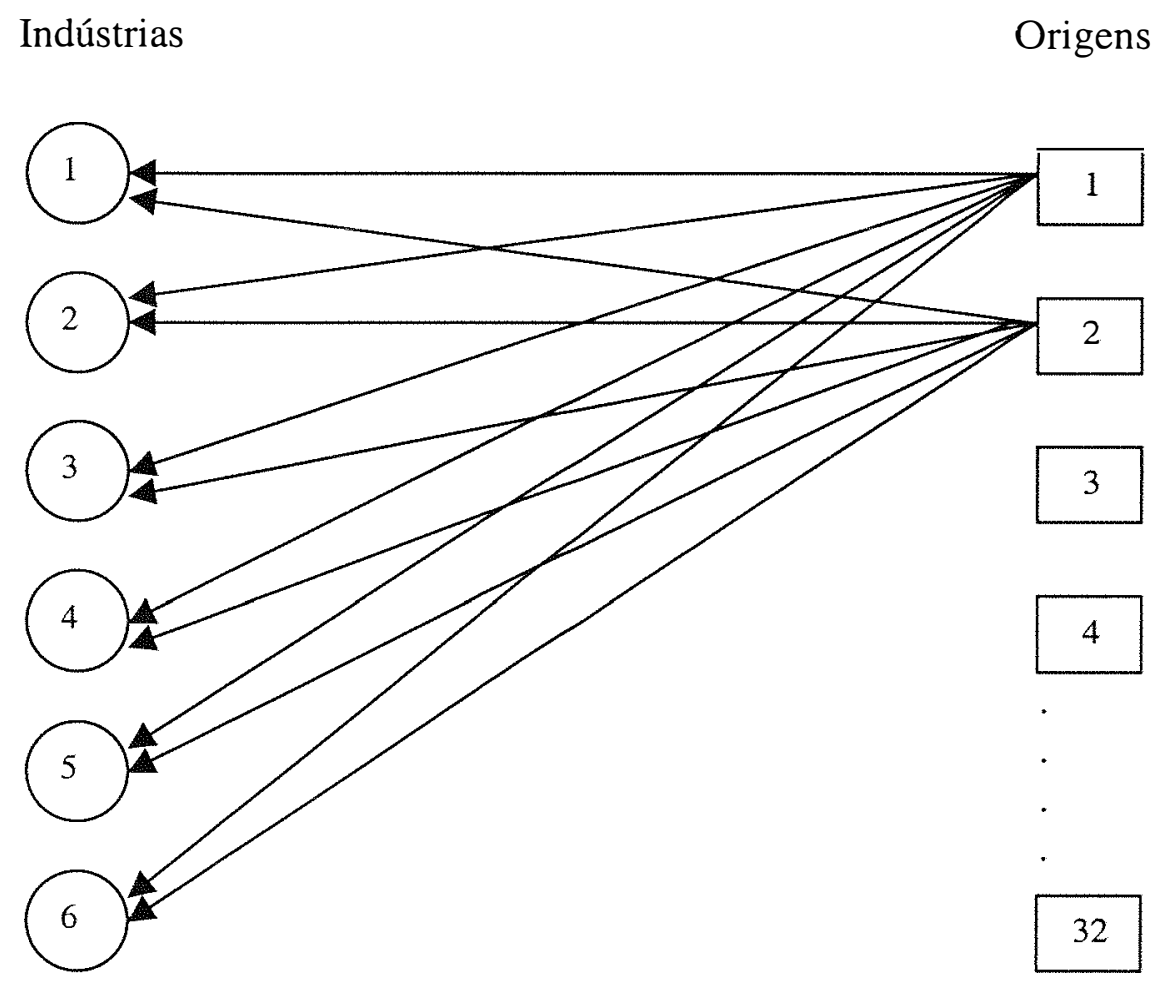

Figura 3 - Representação gráfica do problema de transporte com várias origens e vários destinos (Modelo I).

Segundo Martins (1998), os problemas de transporte normalmente são representados por uma rede composta de nós e arcos que ligam regiões com atividades econômicas interdependentes. O nó é o ponto inicial ou final de uma viagem e o arco a distância que une dois nós. Ainda de acordo com Martins (1998) citando Novaes (1986), considera-se o fluxo entre os nós como uma função inversa à impedância entre a origem e o destino e que esta função impedância pode ser caracterizada por parâmetros como 
tempo de viagem, custo de transporte ou distância física. Duran et al. (1985) recomendam que sempre se utilize o custo de transporte como a unidade de medida (impedância) nos modelos econômicos, uma vez que apenas o uso de distâncias pode dar resultados destorcidos do ponto de vista da análise econômica.

As fazendas e as indústrias são aqui vistas como nós interligados pela rede de estradas. Este elo de ligação ou arco pode ser medido em qualquer parâmetro relevante, podendo representar custo de transporte $(\mathrm{R} \$ / \mathrm{t} . / \mathrm{km})$ como é o nosso caso, mas também poderia ser tempo de viagem (minutos), renda (R $\$ / U S \$$ ) ou mesmo um índice de beleza cênica, concordando com Dykstra (1984).

Tabela 11. Terminologia utilizada no Modelo I.

\begin{tabular}{l|l}
\hline Problema Geral & Problema Específico \\
\hline Unidade de medida da commodity & $\begin{array}{l}\text { Toneladas de toras curtas de eucalipto } \\
32 \text { fazendas } \\
6 \text { fábricas } \\
\text { "m" fontes ou origens }\end{array}$ \\
"n" destinos & $\begin{array}{l}\text { Toneladas disponíveis na fazenda } \mathrm{i} \\
\text { Toneladas alocadas na fábrica } \mathrm{j} \\
\text { Oferta Oi da origem i } \\
\text { Demanda Dj no destino j } \\
\text { Custo Cij por unidade trazida da origem i de uma tonelada transportada da } \\
\text { para o destino } \mathrm{j}\end{array}$ \\
\hline
\end{tabular}

Fonte: Hillier \& Lieberman (1995)

\subsubsection{Formulação teórica do Modelo I}

Hadley (1982) e Williams (1993) descrevem o modelo matemático do problema de transporte que serve de suporte para a estrutura do modelo utilizado neste trabalho. 
Minimizar: $\quad Z=\sum_{i=1}^{m} \sum_{j=1}^{n} C_{i j} X_{i j}$

sujeito a:

$$
\begin{aligned}
& \sum_{i=1}^{m} X_{\mathrm{ij}}=\mathrm{D}_{\mathrm{j}} \quad \text { para } \mathrm{j}=1, \ldots \mathrm{n} \\
& \sum_{j=1}^{n} X_{\mathrm{ij}}=\mathrm{O}_{\mathrm{i}} \quad \text { para } \mathrm{i}=1, \ldots \ldots \mathrm{m} \\
& \sum_{i=1}^{m} O i=\sum_{j=1}^{n} D j=\sum_{i=1}^{m} \sum_{j=1}^{n} X i j \\
& X i j \geq 0 ; \quad \mathrm{i}=1, \ldots . \mathrm{m} ; \quad \mathrm{j}=1, \ldots \ldots . \mathrm{n}
\end{aligned}
$$

Onde :

$\mathrm{Z} \quad$ = custo total de transporte da madeira em reais $(\mathrm{R} \$)$;

$\mathrm{C}_{\mathrm{ij}}=$ custo de transporte de uma tonelada de madeira para a rota que vai da fazenda $\mathrm{i}$ até a indústria j (R $\$$ tonelada/rota);

$\mathrm{X}_{\mathrm{ij}}=$ quantidade de madeira transportada $\mathrm{n}$ a rota de abastecimento que une a fazenda $\mathrm{i}$ à indústria $\mathrm{j}$ (toneladas/ano);

$\mathrm{m}$ = número de fazendas fornecedoras de madeira;

$\mathrm{n}$ = número de indústrias consumidoras de madeira;

$\mathrm{D}_{\mathrm{j}}=$ total anual em toneladas de madeira demandadas por cada uma das " $\mathrm{j}$ " indústrias;

Oi = total anual em toneladas de madeira ofertadas por cada uma das " $\mathrm{i}$ " fazendas.

A restrição (4) nos mostra que o sistema é balanceado, isto é, o somatório das quantidades ofertadas é igual ao somatório das quantidades demandadas, com "m x n" variáveis e, para este problema em particular, deve-se levantar as seguintes informações básicas:

a) oferta de madeira de cada uma das " $m$ " fontes produtoras, em toneladas/ano;

b) custo unitário de transporte da madeira (frete) para cada uma das "ij" rotas, em $\mathrm{R} \$ /$ tonelada/Km;

c) demanda de madeira de cada uma das "n" indústrias, em toneladas/ano. 


\subsubsection{A matriz dos custos de transporte do Modelo I}

Os custos de transporte foram definidos com base em dados primários. $\mathrm{O}$ levantamento de informações junto às indústrias se constitui em uma das fases mais difíceis e onerosas da modelagem. Primeiramente foi necessário desenvolver uma tabela de valores médios de fretes (Tabela 12) em $\mathrm{R} \$ /$ tonelada $/ \mathrm{km}$ para estradas pavimentadas sem fazer referências ou considerações de classe ou qualidade de estradas, tipos de caminhão utilizados no transporte, existência ou não de pedágios e balanças e limites de velocidades, o que já se considera como componentes dos valores de fretes levantados.

Tabela 12. Valores de frete para o transporte principal de toras curtas de eucalipto, em $\mathrm{R} \$ / \mathrm{t}$. /Km, referentes ao ano de 1996.

\begin{tabular}{cllllll}
\hline $\begin{array}{l}\text { Indústrias } \Rightarrow \\
\text { Distâncias } \Downarrow\end{array}$ & CH & DU & EU & LW & RI & SU \\
\hline 0 a $200 \mathrm{Kms}$ & 0,042 & 0,048 & 0,058 & 0,047 & 0,043 & 0,043 \\
201 a $400 \mathrm{Kms}$ & 0,024 & 0,027 & 0,028 & 0,027 & 0,025 & 0,027 \\
$>400 \mathrm{kms}$ & 0,019 & 0,013 & 0,024 & 0,014 & 0,021 & 0,021 \\
\hline
\end{tabular}

Fonte: Indústrias e Florestar Estatístico (1996)

Desenvolveu-se em seguida uma tabela de distâncias (Tabela 13) para as rotas alternativas identificadas no mapa da "Revista Quatro Rodas", de 1996, como sendo o menor percurso de rodovias pavimentadas para interligar os municípios de localização das fazendas (origens) com os municípios de localização das fábricas (destinos).

Observando-se a Tabela 13, percebe-se que $15,1 \%$ das rotas se enquadram dentro da distância de zero a 200 quilômetros de percurso de viagem de ida e volta, $26,6 \%$ na distância de 200 a 400 quilômetros e 58,3\% com percurso acima de 400 quilômetros. 
Tabela 13. Distâncias em quilômetros para o transporte principal, nas rotas de abastecimento disponíveis no ano de 1996.

\begin{tabular}{|c|c|c|c|c|c|c|c|}
\hline $\begin{array}{c}\text { Faz } \text { Ind } \\
\Downarrow_{\mathrm{i}} \Rightarrow \mathrm{j}\end{array}$ & $\begin{array}{c}\mathrm{CH} \\
\text { M.Guaçu }\end{array}$ & $\begin{array}{c}\text { DU } \\
\text { Botucatu }\end{array}$ & $\begin{array}{c}\text { EU } \\
\text { Salto }\end{array}$ & $\begin{array}{c}\text { LW } \\
\text { L.Paulista } \\
\end{array}$ & $\begin{array}{c}\text { RI } \\
\text { Americana }^{2} \\
\end{array}$ & $\begin{array}{c}\text { SU } \\
\text { Suzano } \\
\end{array}$ & $\begin{array}{l}\text { Município } \\
\text { (Fazendas) } \\
\end{array}$ \\
\hline$\overline{\mathrm{CH}_{1}}$ & 79 & 549 & 277 & 551 & 211 & 561 & M.Guaçu \\
\hline $\mathrm{CH}_{2}$ & 418 & 316 & 396 & 294 & 324 & 654 & Brotas \\
\hline $\mathrm{CH}_{3}$ & 326 & 552 & 436 & 506 & 294 & 654 & S.Rta.P.Quatro \\
\hline $\mathrm{CH}_{4}$ & 684 & 254 & 518 & 144 & 510 & 790 & Agudos \\
\hline $\mathrm{CH}_{5}$ & 586 & 330 & 276 & 412 & 362 & 458 & Itapetininga \\
\hline $\mathrm{CH}_{6}$ & 414 & 678 & 710 & 578 & 514 & 906 & Altinópolis \\
\hline $\mathrm{CH}_{7}$ & 376 & 692 & 326 & 774 & 340 & 334 & Piracaia \\
\hline $\mathrm{CH}_{8}$ & 546 & 176 & 436 & 182 & 424 & 644 & Avaré \\
\hline $\mathrm{DU}_{1}$ & 502 & 60 & 338 & 142 & 424 & 588 & Botucatu \\
\hline $\mathrm{DU}_{2}$ & 558 & 120 & 364 & 202 & 416 & 596 & Itatinga \\
\hline $\mathrm{DU}_{3}$ & 553 & 191 & 469 & 162 & 555 & 719 & L. Paulista \\
\hline $\mathrm{EU}_{1}$ & 250 & 340 & 46 & 422 & 194 & 326 & Itu \\
\hline $\mathrm{EU}_{2}$ & 222 & 330 & 12 & 412 & 160 & 316 & Salto \\
\hline $\mathrm{EU}_{3}$ & 352 & 416 & 152 & 498 & 294 & 338 & Pirapora \\
\hline $\mathrm{EU}_{4}$ & 442 & 506 & 246 & 563 & 384 & 440 & Pilar do Sul \\
\hline $\mathrm{EU}_{5}$ & 554 & 184 & 444 & 190 & 432 & 652 & Avaré \\
\hline $\mathrm{EU}_{6}$ & 536 & 94 & 372 & 176 & 458 & 622 & Botucatu \\
\hline $\mathrm{LW}_{1}$ & 550 & 188 & 466 & 82 & 552 & 716 & Borebi \\
\hline $\mathrm{LW}_{2}$ & 528 & 90 & 334 & 172 & 386 & 566 & Itatinga \\
\hline $\mathrm{RI}_{1}$ & 351 & 513 & 505 & 557 & 345 & 705 & São Simão \\
\hline $\mathrm{RI}_{2}$ & 376 & 478 & 432 & 410 & 300 & 638 & Ibaté \\
\hline $\mathrm{RI}_{3}$ & 470 & 288 & 486 & 288 & 406 & 744 & Boa Esp. do Sul \\
\hline $\mathrm{RI}_{4}$ & 266 & 324 & 316 & 332 & 220 & 556 & Itirapina \\
\hline $\mathrm{RI}_{5}$ & 497 & 135 & 413 & 29 & 499 & 663 & L. Paulista \\
\hline $\mathrm{RI}^{6}$ & 626 & 256 & 516 & 262 & 504 & 724 & Avaré \\
\hline $\mathrm{RI}_{7}$ & 833 & 515 & 623 & 597 & 729 & 835 & Itararé \\
\hline $\mathrm{RI}_{8}$ & 190 & 488 & 146 & 570 & 140 & 346 & Campinas \\
\hline $\mathrm{SU}_{1}$ & 560 & 682 & 412 & 764 & 482 & 124 & Salesópolis \\
\hline $\mathrm{SU}_{2}$ & 655 & 837 & 579 & 919 & 565 & 345 & S. L. Paraitinga \\
\hline $\mathrm{SU}_{3}$ & 432 & 496 & 236 & 553 & 374 & 430 & Pilar do Sul \\
\hline $\mathrm{SU}_{4}$ & 572 & 134 & 408 & 216 & 430 & 610 & Itatinga \\
\hline $\mathrm{SU}_{5}$ & 828 & 510 & 618 & 592 & 724 & 830 & Itararé \\
\hline
\end{tabular}

Fonte: Mapa Rodoviário da Revista Quatro Rodas (1996)

\footnotetext{
${ }^{2}$ A fábrica da Ripasa S/A encontra-se localizada dentro do município da cidade de Limeira, porém muito próxima ao perímetro urbano da cidade de Americana, motivo pelo qual esta última é tomada como referência para definição de rotas e cálculo de distâncias.
} 
A média total das rotas componentes da Tabela 13, em termos de distância de percurso, é de 432 quilômetros, porém a média das rotas efetivamente utilizadas ou praticadas pelas indústrias no ano de 1996 é de 291 quilômetros de percurso.

Os valores da Tabela 14, que constituem a matriz dos custos de transporte, foram, em parte, fornecidos diretamente pelas empresas e representam a situação do fluxo de madeira efetivamente praticado pelas indústrias no ano de 1996 e outra parte dos valores foi estimada utilizando-se as tabelas 12 e 13.

A Tabela 14 constitui a matriz origem-destino dos coeficientes de custos de transporte de tamanho "m x n", que define o número de variáveis da função objetivo com "m $+n "$ restrições. Ela é básica para a solução dos modelos matemáticos de programação linear referentes ao problema de transporte, cujos resultados irão subsidiar os estudos de avaliação do sistema de transporte principal praticado pelas indústrias.

A primeira coluna da tabela mostra as fazendas produtoras de matéria-prima e os municípios tomados como referências para suas localizações. Os elementos internos da matriz são os coeficientes "Cij" da função objetivo do modelo de transporte e representam os custos de se movimentar uma tonelada de toras curtas de eucalipto em cada rota. A última linha e a última coluna representam respectivamente as demandas anuais de matéria-prima de cada indústria consumidora e as ofertas anuais de cada fazenda. 
Tabela 14. Matriz dos custos de transporte rodoviário de toras curtas de eucalipto (R\$/t.) no estado de São Paulo, para o ano de 1996.

\begin{tabular}{|c|c|c|c|c|c|c|c|}
\hline $\begin{array}{l}\text { Indústrias } \mathrm{j} \Rightarrow \\
\text { Fazendas I } \Downarrow\end{array}$ & $\begin{array}{c}\mathrm{CH} \\
\text { M.Guaçu }\end{array}$ & $\begin{array}{c}\text { DU } \\
\text { Botucatu }\end{array}$ & $\begin{array}{c}\text { EU } \\
\text { Salto } \\
\end{array}$ & $\begin{array}{c}\text { LW } \\
\text { L.Paulista } \\
\end{array}$ & $\begin{array}{c}\text { RI } \\
\text { Americana } \\
\end{array}$ & $\begin{array}{c}\text { SU } \\
\text { Suzano }\end{array}$ & $\begin{array}{l}\text { Oferta } \\
\text { Oi (t./ano) }\end{array}$ \\
\hline $\mathrm{CH}_{1} / \mathrm{M} . \mathrm{Gu}$ & 3,33 & 7,02 & 7,74 & 7,66 & 9,01 & 11,59 & 588884,9 \\
\hline $\mathrm{CH}_{2} /$ Brotas & 9,91 & 8,60 & 11,07 & 8,05 & 8,15 & 13,51 & 233208,9 \\
\hline $\mathrm{CH}_{3} / \mathrm{SRPQ}$ & 7,73 & 7,05 & 10,67 & 7,03 & 7,39 & 13,51 & 67060,56 \\
\hline $\mathrm{CH}_{4} / \mathrm{Agud}$ & 13,00 & 6,91 & 12,68 & 6,71 & 10,66 & 16,32 & 34145,8 \\
\hline $\mathrm{CH}_{5} /$ Itapet. & 11,14 & 8,98 & 7,72 & 11,28 & 9,10 & 9,46 & 131771 \\
\hline $\mathrm{CH}_{6} /$ Altino & 9,81 & 8,66 & 17,38 & 8,03 & 10,75 & 18,72 & 8090,6 \\
\hline $\mathrm{CH}_{7} /$ Piraca & 8,91 & 8,84 & 9,11 & 10,76 & 8,55 & 9,04 & 20268,9 \\
\hline $\mathrm{CH}_{8}$ /Avaré & 10,38 & 8,51 & 10,67 & 8,48 & 10,66 & 13,31 & 63680,08 \\
\hline $\mathrm{DU}_{1} /$ Botuc & 9,54 & 2,90 & 9,45 & 6,61 & 10,66 & 12,15 & 159218,2 \\
\hline $\mathrm{DU}_{2} /$ Itating & 10,61 & 5,80 & 10,18 & 9,41 & 10,46 & 12,31 & 16241,44 \\
\hline $\mathrm{DU}_{3} / \mathrm{L} . \mathrm{Paul}$ & 10,51 & 9,24 & 11,48 & 7,55 & 11,60 & 14,85 & 371904,2 \\
\hline $\mathrm{EU}_{\mathrm{l}} / \mathrm{Itu}$ & 5,93 & 9,25 & 2,65 & 11,56 & 8,28 & 8,82 & 18562 \\
\hline $\mathrm{EU}_{2} /$ Salto & 5,26 & 8,98 & 0,69 & 11,28 & 6,83 & 8,55 & 11521 \\
\hline $\mathrm{EU}_{3} /$ Pirapo & 8,34 & 11,32 & 8,77 & 6,92 & 7,39 & 9,15 & 16295 \\
\hline $\mathrm{EU}_{4} / \mathrm{P} . \operatorname{do} S$ & 8,40 & 6,47 & 6,88 & 7,82 & 9,66 & 9,09 & 40983 \\
\hline $\mathrm{EU}_{5} / \mathrm{Av}$ varé & 10,53 & 8,90 & 10,87 & 8,85 & 9,03 & 13,47 & 62006 \\
\hline $\mathrm{EU}_{6} /$ Botuc & 10,19 & 4,55 & 10,40 & 8,20 & 9,58 & 12,85 & 246687 \\
\hline $\mathrm{LW}_{1} /$ Bore & 10,46 & 5,11 & 11,41 & 3,82 & 11,54 & 14,79 & 211048,1 \\
\hline $\mathrm{LW}_{2} /$ Itating & 10,04 & 4,35 & 9,34 & 8,01 & 9,71 & 11,69 & 43061,97 \\
\hline $\mathrm{RI}_{1} / \mathrm{S} . \mathrm{Sim}$ & 8,32 & 6,56 & 12,36 & 7,74 & 8,68 & 14,57 & 35451,5 \\
\hline $\mathrm{RI}_{2} /$ Ibaté & 8,91 & 6,11 & 10,57 & 11,23 & 7,54 & 13,18 & 100076,2 \\
\hline $\mathrm{RI}_{3} / \mathrm{BedoS}$ & 8,93 & 7,84 & 11,90 & 7,89 & 10,21 & 15,37 & 96035,2 \\
\hline $\mathrm{RL}_{4} / \mathrm{Itirapin}$ & 6,31 & 8,81 & 8,83 & 9,09 & 9,39 & 11,49 & 84358,9 \\
\hline $\mathrm{RI}_{5} / \mathrm{L} . \mathrm{Paul}$ & 9,45 & 6,53 & 11,55 & 1,35 & 10,43 & 13,70 & 116890,2 \\
\hline $\mathrm{RI}_{6} /$ Avaré & 11,90 & 6,96 & 12,63 & 7,17 & 10,54 & 14,96 & 128235,6 \\
\hline $\mathrm{RI}_{7} / \mathrm{Itararé}$ & 15,84 & 6,58 & 15,25 & 8,30 & 15,24 & 17,25 & 200733 \\
\hline $\mathrm{RI}_{8} /$ Campin & 8,01 & 6,24 & 8,43 & 7,92 & 5,98 & 9,37 & 53099 \\
\hline $\mathrm{SU}_{1} /$ Saleso & 10,65 & 8,72 & 11,52 & 10,62 & 10,08 & 5,29 & 207690,5 \\
\hline $\mathrm{SU}_{2} / \mathrm{SLPar}$ & 12,45 & 10,70 & 14,17 & 12,77 & 11,81 & 9,34 & 68550,7 \\
\hline $\mathrm{SU}_{3} / \mathrm{P}$.do $\mathrm{S}$ & 8,21 & 6,34 & 6,60 & 7,69 & 9,41 & 8,88 & 492055,2 \\
\hline $\mathrm{SU}_{4} /$ Itating & 10,87 & 6,48 & 11,41 & 10,06 & 8,99 & 12,60 & 338562,7 \\
\hline $\mathrm{SU}_{5} /$ Itararé & 15,74 & 6,52 & 15,13 & 8,23 & 15,14 & 17,15 & 89045,1 \\
\hline Dj (t./ano) & 1147111 & 547363,8 & 396054 & 254110,1 & 814879,6 & 1195904 & 4355422 \\
\hline
\end{tabular}

Fonte: Consulta às indústrias e estimativas deste estudo 


\subsubsection{Formulação matemática do Modelo I}

Com base nas informações contidas na Tabela 14 e com os valores definidos para as restrições de demanda e de oferta de madeira para o modelo I, tem-se:

Função objetivo : $\mathrm{Z}=\sum_{i=1}^{32} \sum_{j=1}^{6} \mathrm{Cij} \mathrm{Xij}$

Minimizar "Z" sujeito a :

$$
\begin{aligned}
& \sum_{i=1}^{32} \mathrm{Xij} \geq \mathrm{Dj} \quad \text { para } \mathrm{j}=1 \text { a } 6 \\
& \sum_{j=1}^{6} \mathrm{Xij} \leq \mathrm{Oi} \quad \text { para } \mathrm{i}=1 \text { a } 32 \\
& \sum_{i=1}^{32} \mathrm{Oi}=\sum_{j=1}^{6} \mathrm{Dj}=\sum_{i=1}^{32} \sum_{j=1}^{6} \mathrm{Xij}=4.355 .422,42 \\
& \mathrm{Xij} \geq 0 ; \quad \mathrm{i}=1 \text { a } 6 ; \quad \mathrm{j}=1 \text { a } 32
\end{aligned}
$$

Onde:

$\mathrm{Z}$ = custo mínimo total do transporte principal das toras de eucalipto, em reais ( $\mathrm{R} \$$ );

$\mathrm{Cij}=$ coeficientes da Tabela 14 , em reais para transportar uma tonelada de toras de eucalipto por rota;

Xij = variável de decisão, em total de toneladas anualmente transportadas na rota $\mathrm{ij}$, para abastecimento da indústria j;

$\mathrm{m}=32$;

$\mathrm{n}=6$;

$\mathrm{Dj}=$ demanda total anual, em toneladas de toras de eucalipto, de cada uma das seis indústrias (última linha da Tabela 14);

$\mathrm{Oi}=$ capacidade limite anual de oferta em toneladas de toras de eucalipto de cada uma das trinta e duas fazendas (última coluna da Tabela 14). 


\subsubsection{Pressuposições e limitações do Modelo I}

- O modelo representa a realidade para o período de um ano (1996);

- O modelo é aplicado para as condições da região leste do estado de São Paulo;

- Consideram-se inexistentes os vínculos de propriedade entre fazendas e indústrias;

- A madeira toras curtas de eucalipto é considerada uma commodity;

- As fazendas foram agregadas em torno do município mais próximo tomado como referência para cálculo das distâncias no mapa;

- As rotas são consideradas disponíveis e acessíveis durante todo o ano;

- Os custos de transporte não fazem referência à existência ou não de estradas de terra;

- Os custos de transporte não fazem referência ao tipo de caminhão utilizado no transporte principal da madeira no que diz respeito à capacidade de carga, idade, estado de conservação ou adaptações;

- Para os cálculos no trabalho, consideram-se os caminhões trabalhando a plena capacidade de carga;

- Considera-se que os caminhões retornem vazios pelo mesmo trajeto da viagem de ida;

- O enfoque do trabalho é no trajeto de viagem efetivamente percorrido pelos caminhões, aquele trajeto cujo tempo de percurso é função da distância de ida e volta na rota considerada.

\subsection{Modelo de transporte com várias origens e vários destinos, definindo o tipo de caminhão (Modelo II)}

Este modelo surge como uma variação do modelo I, com a indagação de qual seria o efeito da inclusão da variável "tipo de caminhão" no sistema. O modelo II também utiliza o modelo de programação linear para minimizar o custo total de transporte de toras curtas de eucalipto. 
A solução ótima para o modelo com a variável de decisão "número de viagens por rota" define qual o "tipo de caminhão" mais indicado do ponto de vista econômico para ser usado em cada rota. Permite ainda inferir sobre os ganhos com a inclusão da variável "tipo de caminhão" no modelo I. Em uma perspectiva mais ampla, os resultados do modelo II definindo "tipo de caminhão" permitem avaliar o processo de terceirização do transporte principal de madeira, largamente difundido entre as indústrias. A autonomia da indústria sobre a composição e dimensionamento da frota, definição do tipo e alocação dos caminhões implicam em propriedade dos mesmos ou em verticalização do transporte principal da madeira, tendência inversa ao processo de terceirização.

Das seis indústrias que participam deste estudo, três têm o transporte principal de madeira totalmente terceirizado, duas, parcialmente terceirizado e uma trabalhando com $100 \%$ de frota própria (verticalizada).

O fato de existirem três formas organizacionais de transporte principal de madeira (terceirização total, terceirização parcial e verticalização total) sendo utilizadas dentro de uma mesma malha rodoviária em um mesmo período de tempo e em diferentes graus de adoção por parte das indústrias atesta as incertezas existentes a respeito das vantagens e desvantagens da adoção de qualquer uma delas.

"Embora a terceirização dos serviços de transporte principal seja quase uma unanimidade no que diz respeito à forma organizacional adotada, as empresas que utilizam esses serviços estão constantemente questionando a sua eficiência tanto do ponto de vista financeiro como operacional", Ribeiro (1998).

$\mathrm{O}$ autor acrescenta ainda como justificativa apresentada pelas indústrias para o fato da terceirização parcial a necessidade delas garantirem estratégias que assegurem o abastecimento das fábricas e a obtenção de parâmetros de comparação de custos que permitam negociações baseadas em informações mais precisas. 


\subsubsection{Formulação teórica do Modelo II}

Os trabalhos de Novaes (1978) e Duran et al. (1985) apresentam um modelo geral variante do modelo de transporte. É o caso de um ou mais produtos serem transportados utilizando-se diferentes meios de transporte, na situação de diversas origens e um único destino. Para a modelagem do problema de transporte com várias origens e vários destinos, tomou-se como referência a formulação de programação linear não-inteira apresentada por Seixas (1992). A formulação inicial é ligeiramente alterada para poder discernir melhor os diferentes tipos de caminhão mais comumente utilizados pelas indústrias no transporte de toras curtas de eucalipto (Figura 4).

Minimizar $\mathrm{Z}=\sum_{i=1}^{m} \sum_{j=1}^{n} \sum_{k=1}^{l} \mathrm{~B}_{\mathrm{ijk}} \mathrm{q}_{\mathrm{ijk}}$

sujeito a :

$$
\begin{aligned}
& \sum_{i=1}^{m} \sum_{k=1}^{l} \mathrm{CC}_{\mathrm{k}} \mathrm{q}_{\mathrm{ijk}} \geq \mathrm{D}_{\mathrm{j}} \quad \mathrm{p} / \mathrm{j}=1, \ldots . \mathrm{n} \\
& \sum_{j=1}^{n} \sum_{k=1}^{l} \mathrm{CC}_{\mathrm{k}} \mathrm{q}_{\mathrm{ijk}} \leq \mathrm{O}_{\mathrm{i}} \quad \mathrm{p} / \mathrm{i}=1, \ldots \ldots \mathrm{m} \\
& \mathrm{q}_{\mathrm{ij} \mathrm{k}} \geq 0 ; \quad \mathrm{i}=1, \ldots . \mathrm{m} ; \quad \mathrm{j}=1, \ldots . \mathrm{n} ; \quad \mathrm{k}=1, \ldots . \mathrm{l}
\end{aligned}
$$

Onde:

$\mathrm{Z}=$ custo do transporte principal de toras de eucalipto em reais $(\mathrm{R} \$)$;

$B_{i j k}=$ custo de uma viagem de ida e volta no transporte principal da madeira ofertada na rota "ij" utilizando-se o caminhão tipo "k" (R\$/viagem/ k / ij);

$\mathrm{q}_{\mathrm{i} j \mathrm{k}}=$ número de viagens de ida e volta do caminhão tipo "k" na rota "ij";

$\mathrm{CC}_{\mathrm{k}}=$ capacidade de carga do caminhão do tipo $\mathrm{k}$, em toneladas;

$\mathrm{m}$ = número de fazendas ou de origens da madeira; 
$\mathrm{n}$ = número de indústrias envolvidas no trabalho;

$\mathrm{l}=$ tipos diferentes de caminhões utilizados no trabalho;

$\mathrm{Oi}=$ oferta em toneladas de toras de eucalipto de cada uma das origens (fazendas);

$\mathrm{Dj}=$ demanda em toneladas de toras de eucalipto, de cada uma das indústrias.

Tabela 15. Terminologia utilizada no Modelo II.

\begin{tabular}{|c|c|}
\hline Problema Geral & Problema Específico \\
\hline Unidade de medida & Viagens de caminhão (ida e volta) \\
\hline "m" fontes ou origens & 32 fazendas \\
\hline "n" destinos & 6 fábricas \\
\hline Oferta Oi da origem i & Toneladas disponíveis na fazenda i \\
\hline Demanda $\mathrm{Dj}$ no destino $\mathrm{j}$ & Toneladas alocadas na fábrica $\mathrm{j}$ \\
\hline $\begin{array}{l}\text { Custo Bijk por unidade de medida } \\
\text { por trajeto da origem } \mathrm{i} \text { até o destino } \mathrm{j}\end{array}$ & $\begin{array}{l}\text { Custo de uma viagem efetuada na rota que vai da fazenda } \\
\text { "i" para a fábrica "j", utilizando-se um determinado "tipo } \\
\text { de caminhão k" para fazer o transporte }\end{array}$ \\
\hline
\end{tabular}

Fonte: Hillier \& Lieberman (1995)

\subsubsection{Características dos tipos de caminhão utilizados}

Ao nos referirmos a caminhões, entenda-se caminhão licenciado, com seguros e impostos pagos, emplacado e devidamente equipado com carroceria para se processar o transporte principal rodoviário de toras curtas de eucalipto.

No levantamento efetuado junto às indústrias participantes deste trabalho e através de literatura, identificou-se a predominância do uso de quatro tipos de caminhão identificados como $\mathrm{K}_{1}, \mathrm{~K}_{2}, \mathrm{~K}_{3}$ e $\mathrm{K}_{4}$ (Figura 5), que se enquadram nas características dos tipos de caminhão descritos por Vargas (1989), Seixas e Widmer (1993) e Leite et al. (1993): 


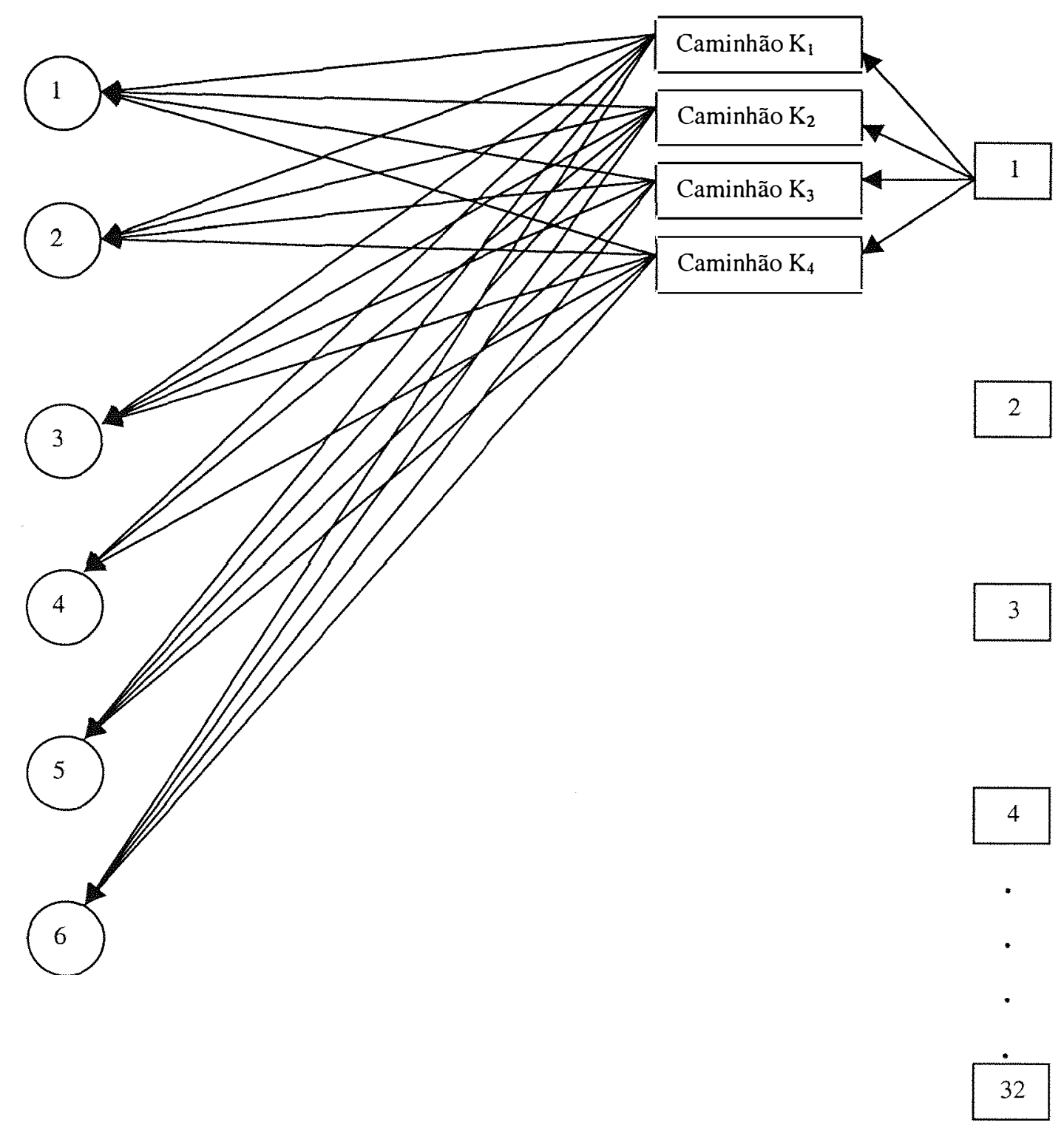

Figura 4 - Representação gráfica do problema de transporte com várias origens e vários destinos, incluindo a opção tipos de caminhão (Modelo II). 


\section{Caminhão simples $\left(\mathbf{k}_{1}\right)$}

Tração: $6 \times 4$ (trucado)

Tara: $8.200 \mathrm{Kg}$

Capacidade de carga: $\mathrm{CC}_{\mathrm{k} 1}=13.800 \mathrm{Kg}$

PBT: $22.000 \mathrm{Kg}$

Potência: $184 \mathrm{CV}$

\section{Caminhão articulado $\left(\mathbf{k}_{2}\right)$}

(Cavalo Mecânico + Reboque de 3 eixos)

Tração: 4 × 2 + SR 3E

Tara: $13.900 \mathrm{Kg}$

Capacidade de carga: $\mathrm{CC}_{\mathrm{k} 2}=26.600 \mathrm{Kg}$

PBT: $40.500 \mathrm{Kg}$

Potência: $321 \mathrm{CV}$

\section{Caminhão articulado $\left(\mathrm{k}_{3}\right)$}

(Cavalo Mecânico + Semi - Reboque de 3 eixos)

Tração: $6 \times 4+$ SR 3E

Tara: $18.700 \mathrm{Kg}$

Capacidade de carga: $\mathrm{CC}_{\mathrm{k} 3}=28.800 \mathrm{Kg}$

PBT: $47.500 \mathrm{Kg} \rightarrow$ Máximo por lei 45,0 t.

Potência: $301 \mathrm{CV}$

\section{Caminhão conjugado ou romeu e julieta $\left(k_{4}\right)$}

Tração: $6 \times 4+$ RQ 3E

Tara: $18.000 \mathrm{Kg}$

Capacidade de carga: $\mathrm{CC}_{\mathrm{k} 4}=49.900 \mathrm{Kg}$

PBT: $68.000 \mathrm{Kg}$

Potência: $394 \mathrm{CV}$ 

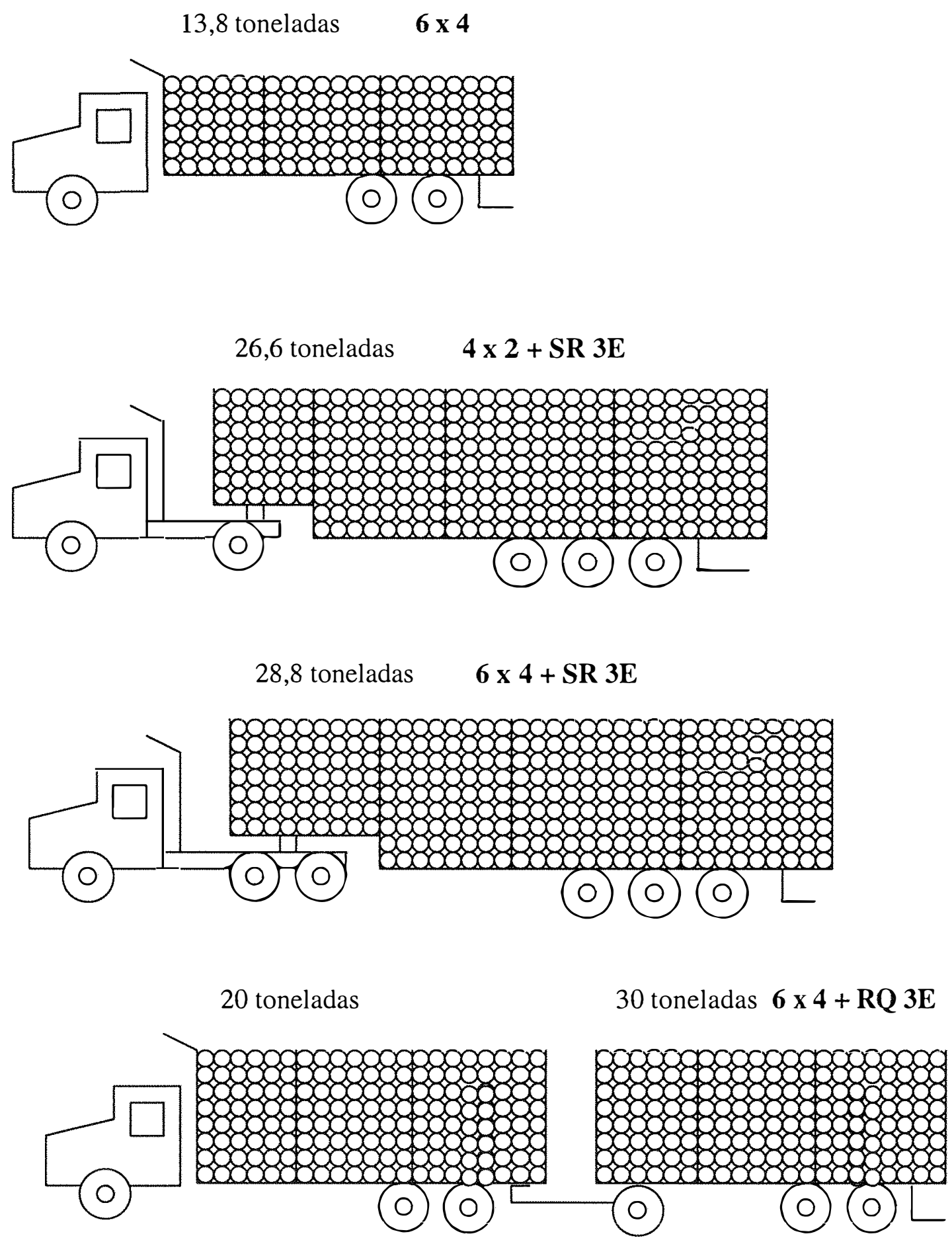

Figura 5 - Tipos de caminhão utilizados pelas indústrias no transporte principal de toras curtas de eucalipto. 


\subsubsection{A matriz dos custos de transporte do Modelo II}

A idéia básica do modelo II é modificar o cenário do modelo I permitindo que as indústrias tenham a oportunidade de optar pelo tipo de caminhão que melhor faça o seu abastecimento de toras curtas de eucalipto, segundo o menor custo de transporte. A estimativa dos coeficientes " $\mathrm{B}_{\mathrm{ijk}}$ " (R $\left.\$ / \mathrm{viagem} / \mathrm{ij} / \mathrm{k}\right)$ que constituem a matriz dos custos de transporte (Tabela 17), que é a base de dados para solução do modelo II, ocorre em cinco etapas a saber:

$\left(1^{a}\right)$ Identificar para cada indústria "j" o "tipo de caminhão" $\left(\mathrm{K}_{1}, \mathrm{~K}_{2}, \mathrm{~K}_{3}\right.$ ou $\left.\mathrm{K}_{4}\right)$ mais freqüentemente utilizado no transporte principal de madeira no ano de 1996, passando estes caminhões a serem considerados representativos das frotas de cada indústria.

Com base na Tabela $14(\mathrm{R} \$ / \mathrm{t} . / \mathrm{ij})$, correlacionar os custos de transporte por indústria com estes tipos de caminhão. Pelo levantamento feito junto às indústrias e por literatura, foram definidos os seguintes "tipos de caminhão" representativos de suas respectivas frotas, segundo a classificação em 6.4.2:
$\mathrm{CH}=$ Caminhão $\mathrm{K}_{3}$
$\mathrm{CCk}_{3}=28,8 \mathrm{t} . /$ viagem
$\mathrm{EU}, \mathrm{RI}, \mathrm{SU}=$ Caminhão $\mathrm{K}_{2}$
$\mathrm{CCk}_{2}=26,6 \mathrm{t} . /$ viagem
$\mathrm{LW}=$ Caminhão $\mathrm{K}_{1}$
$\mathrm{CCk}_{1}=13,8 \mathrm{t} . /$ viagem
$\mathrm{DU}=$ Caminhão $\mathrm{K}_{4}$
$\mathrm{CCk}_{4}=49,9$ t./ viagem

Os valores em $\mathrm{R} \$ /$ t./ij da coluna $\mathrm{CH}$ da Tabela 14 ficam definidos como sendo referentes ao caminhão $\mathrm{K}_{3}$, representativo da frota utilizada pela indústria; os da coluna DU como sendo referentes ao caminhão $\mathrm{K}_{4}$ e assim sucessivamente para todas as indústrias.

$\left(2^{a}\right)$ Ao inserir no modelo a alternativa de diferentes tipos de caminhão para cada rota, é necessário que sejam fornecidas informações sobre os valores dos coeficientes de custos 
de transporte para cada uma destas novas opções de transporte. Na impossibilidade de levantar tais informações junto às indústrias, optou-se por fazer a estimativa destes coeficientes utilizando-se "fatores de correção" (ajustes) para os quatro tipos de caminhão, calculados segundo as equações obtidas por Seixas (1992).

Primeiramente, na Tabela 14, criam-se três novas colunas para cada indústria para abrigar os valores dos coeficientes de custos de transporte das novas opções de tipos de caminhão. Estes novos coeficientes serão ajustados ou estimados pelos "fatores de correção" $\left(f_{i j k}\right)$, gerando uma tabela de transição com parâmetro ainda em $R \$ / t$. (Tabela 16).

$\left(3^{\mathrm{a}}\right)$ Cálculo dos "fatores de correção" $\left(\mathrm{f}_{\mathrm{ijk}}\right)$

A terceira etapa consiste no cálculo dos "fatores de correção" $\left(\mathrm{f}_{\mathrm{ijk}}\right)$, que devido à sua importância e complexidade, é abordado em separado no subitem 6.4.4.

(4 $4^{\mathrm{a}}$ Preencher as novas colunas da Tabela $16 \mathrm{em} \mathrm{R} \$ / \mathrm{t} . / \mathrm{ij} / \mathrm{k}$, utilizando-se os "fatores de correção" calculados.

Os fatores de correção incidirão sempre sobre a coluna dos custos de transporte referentes ao tipo de caminhão representativo da frota da indústria. Procede-se ao ajuste dos valores segundo os respectivos fatores de correção, preenchendo as três colunas gerando a Tabela $16(\mathrm{R} \$ / \mathrm{t}$.). Para cada rota de cada uma das indústrias, existem agora quatro colunas de coeficientes de custos referentes aos quatro tipos de caminhão $\left(\mathrm{K}_{1}\right.$, $\mathrm{K}_{2}, \mathrm{~K}_{3}$ e $\mathrm{K}_{4}$ ).

$\left(5^{a}\right)$ Uma vez concluído o preenchimento da Tabela 16, os coeficientes de custos " $B_{i j k}$ " devem ser definidos no parâmetro exigido pelo modelo II ( $\mathrm{R} \$ / \mathrm{viagem} / \mathrm{ij} / \mathrm{k})$. Para isto, multiplica-se cada coluna da Tabela $16(\mathrm{R} \$ / \mathrm{t}$.) pela capacidade de carga em toneladas $\left(\mathrm{CC}_{\mathrm{k}}\right)$ do respectivo caminhão, obtendo então a Tabela 17. 


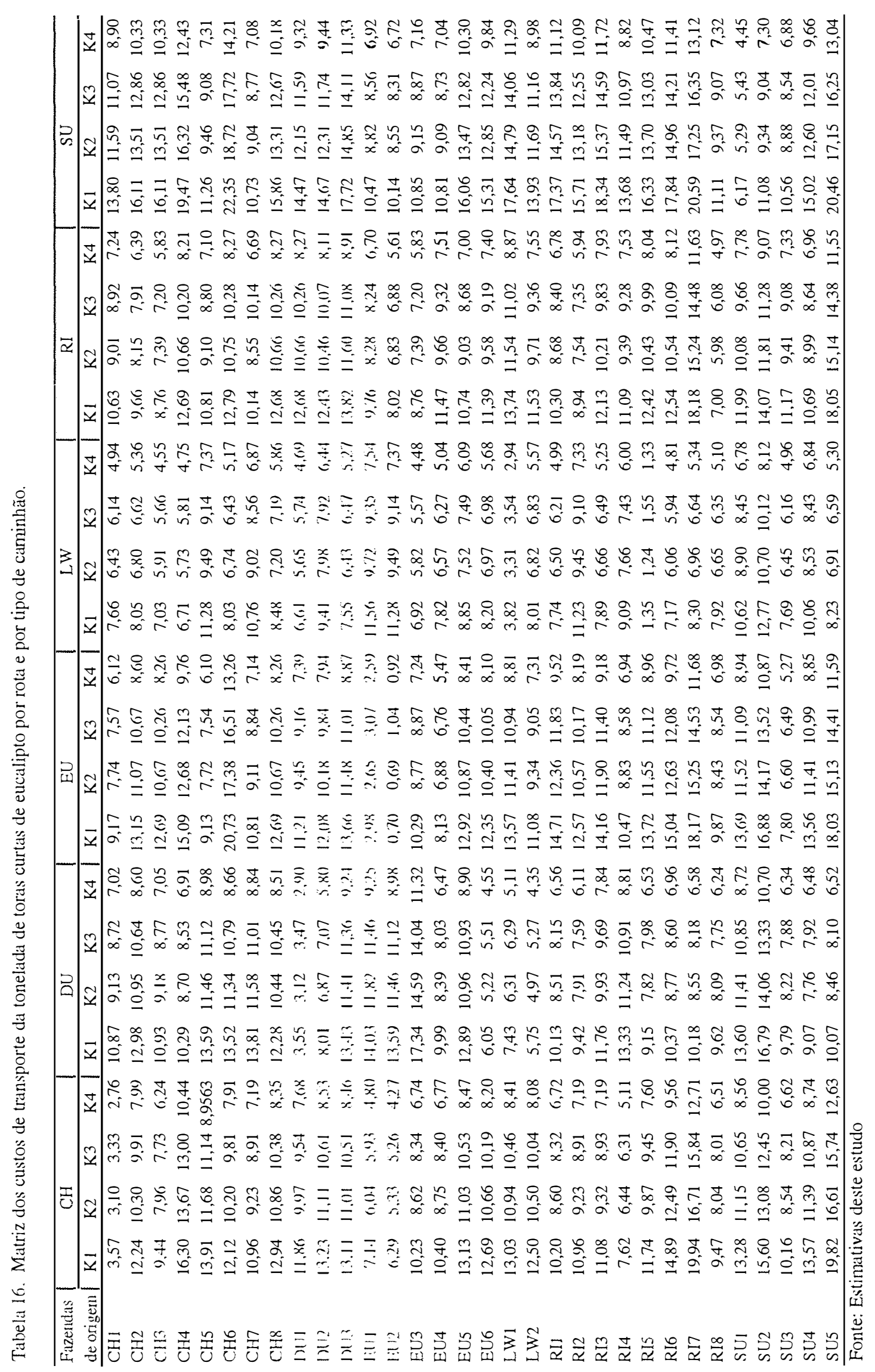




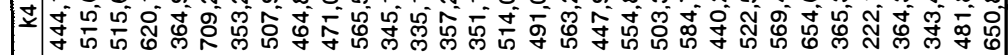

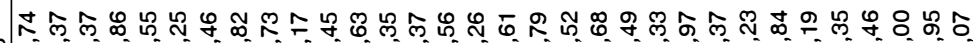

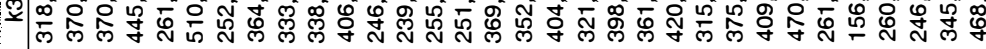

क)

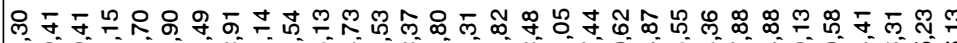

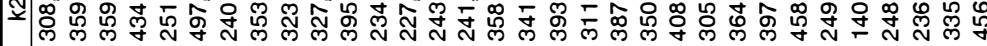
ธ

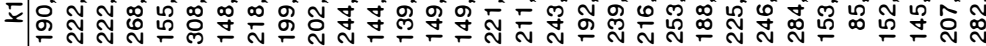

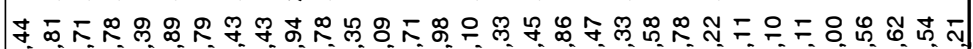

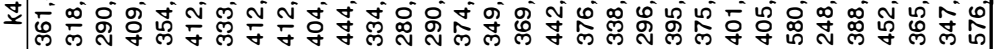
占

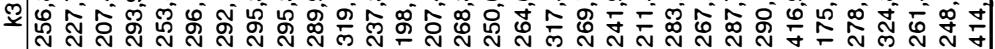

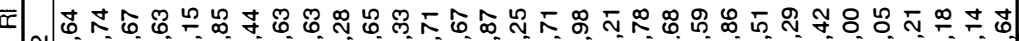

У

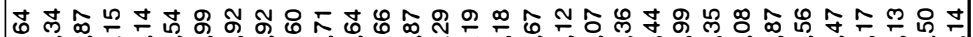

×

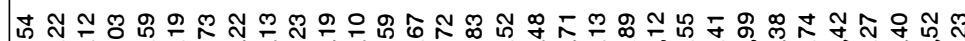

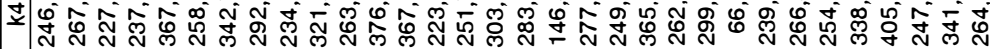

ธำณ

W

3

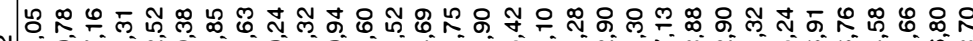

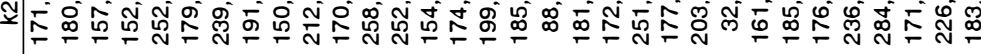

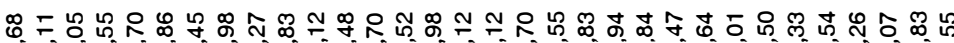

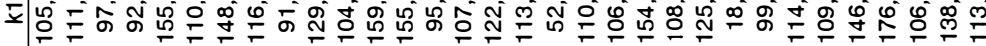

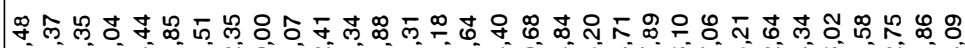

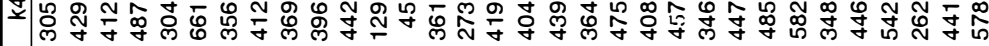

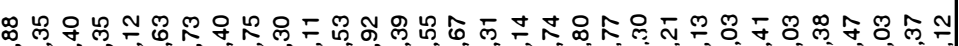

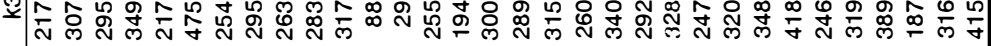

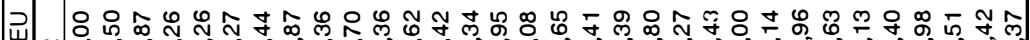

$\checkmark$ ป d

กิ

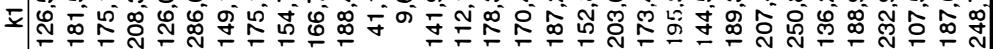
ఐ

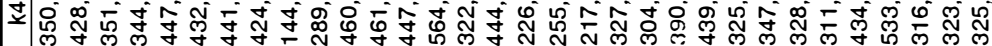

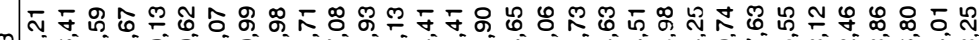

จ

จ

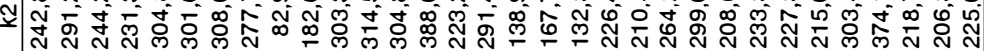

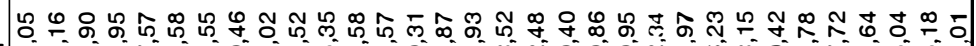

×

궁융ำ

士

ஐ

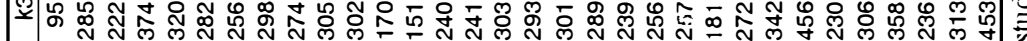

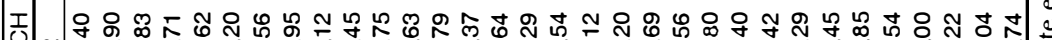

ฐ

స్ \&

$\bar{y}$

要

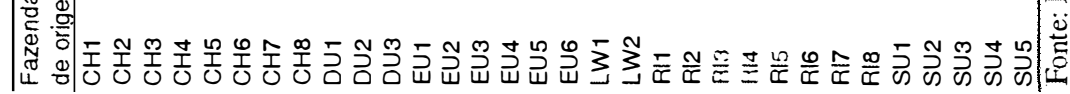




\subsubsection{Cálculo dos fatores de correção $\left(f_{i j k}\right)$}

Os fatores de correção são calculados fazendo-se um estudo comparativo dos custos operacionais entre os quatro tipos de caminhão considerados. Dentro de um cenário comum a todos eles, aplica-se as equações desenvolvidas por Seixas (1992) para cálculo do custo teórico mensal do transporte principal de madeira com o seguinte formato genérico:

$\mathrm{C}_{\mathrm{ijk}}(\mathrm{US} \$)=\mathrm{CFM}_{\mathrm{k}}+\mathrm{Cv}_{\mathrm{k}} \times \mathrm{Km}_{\mathrm{ijk}}$

Onde:

$\mathrm{C}_{\mathrm{ijk}}=$ custo teórico mensal do transporte principal de madeira em dólares americanos, referente ao caminhão "k" trabalhando na rota "ij";

$\mathrm{CFM}_{\mathrm{k}}=$ custo fixo mensal do caminhão do tipo "k";

$\mathrm{Cv}_{\mathrm{k}}=$ custo variável por quilômetro do caminhão do tipo " $\mathrm{k}$ ";

$\mathrm{Km}_{\mathrm{ijk}}=$ quilometragem mensal percorrida pelo caminhão do tipo "k" na rota "ij".

Seixas (1992, p.86) desenvolve uma série de equações para cálculo do custo teórico operacional mensal de veículos trabalhando no transporte principal de madeira, dentre as quais destacamos aquelas referentes aos quatro tipos de caminhão de interesse neste trabalho.

$$
\begin{aligned}
& C_{i j k 1}=3.667,83+0,49 \times \mathrm{km}_{\mathrm{ij} \mathrm{k} 1} \\
& \mathrm{C}_{\mathrm{ijk} 2}=6.390,42+0,78 \times \mathrm{km}_{\mathrm{ij} \mathrm{k} 2} \\
& \mathrm{C}_{\mathrm{ijk} 3}=10.895,80+0,62 \times \mathrm{km}_{\mathrm{ij} \mathrm{k} 3} \\
& \mathrm{C}_{\mathrm{ijk} 4}=12.773,92+0,86 \times \mathrm{km}_{\mathrm{ij} \mathrm{k} 4}
\end{aligned}
$$


O cálculo destes custos depende da quilometragem total percorrida pelos caminhões dentro de cada rota no intervalo de um mês. As quatro equações de números $16,17,18$ e 19, de onde sairão os fatores de correção, serão aplicadas individualmente para cada uma das distâncias das rotas "ij" da Tabela 13, obtendo-se os custos teóricos operacionais mensais para cada um dos quatro tipos de caminhão por rota $\left(C_{i j k 1}, C_{i j k 2}\right.$, $\mathrm{C}_{\mathrm{ijk} 3}$ e $\left.\mathrm{C}_{\mathrm{ijk} 4}\right)$.

O próximo passo é definir o valor de " $\mathrm{Km}_{\mathrm{ijk}}$ ", quilometragem total mensal percorrida pelo caminhão "k" na rota "ij", que por sua vez é função de:

a) Distâncias de transporte (ida e volta) em cada rota "ij" (Tabela 13);

b) Jornada diária de trabalho comum a todas as indústrias para recebimento de madeira (3 turnos de 8 horas);

c) Dias úteis de trabalho comum a todas as indústrias (25 dias por mês);

d) Número de viagens realizadas/tipo de caminhão/ij/dia útil ( $\mathrm{n}^{\circ}$ de viagens/k/ij/dia útil);

e) Calcular $\mathrm{Km}_{\mathrm{ijk}}=(25 \mathrm{dias} / \mathrm{mês}) \times$ ( $\mathrm{n}^{\mathrm{o}}$ de viagens/k/ij/dia útil $) \times\left(\mathrm{Km} / \mathrm{viagem}_{\mathrm{ij}}\right)$.

Os itens "a, b e c" já estão definidos, faltando o item "d" que é abordado separadamente.

\subsubsection{Estimativa do número de viagens realizadas}

O número de viagens realizadas em uma determinada rota depende do tempo consumido em uma viagem completa de ida e volta nesta rota (Tct). Por sua vez, este tempo é função de uma série de fatores tais como: organização da indústria, eficiência das equipes de carga e descarga, manutenção de máquinas e equipamentos utilizados no transporte, da capacidade de carga dos caminhões, das condições de estradas, do tipo de caminhão e principalmente das distâncias de transporte a serem percorridas nas rotas.

Não entram neste trabalho os tempos gastos em filas de espera, tempos de reparos e manutenção, tempo de manobras, paradas para refeições, burocracia na recepção e no despacho dos caminhões. Consideram-se apenas os tempos de carga, 
descarga e demoras que são específicos e constantes para cada tipo de caminhão. portanto não variam entre rotas nem entre indústrias.

O primeiro procedimento é calcular para cada um dos quatro tipos de caminhão o tempo consumido para realizar o percurso de ida e volta por rota (Tct). O percurso consta de viagem sem carga (vs/c) saindo da fábrica, indo até ao povoamento na fazenda e de viagem com carga (vc/c) saindo do povoamento e retornando para a fábrica. Os tempos em minutos que compõem este ciclo de transporte ou de viagem (Tct) são valores médios considerados constantes para cada tipo de caminhão e obtidos segundo informações fornecidas pelas indústrias e coletadas em Seixas (1992) e Leite (1993), onde:

Para o caminhão $\mathrm{K}_{1}($ carga + descarga + demoras $)=21^{\prime}+10^{\prime}+10^{\prime}=41^{\prime}$, Para o caminhão $\mathrm{K}_{2}($ carga + descarga + demoras $)=30^{\prime}+13^{\prime}+14^{\prime}=57^{\prime}$, Para o caminhão $\mathrm{K}_{3}($ carga + descarga + demoras $)=38^{\prime}+18^{\prime}+22^{\prime}=78^{\prime}$, Para o caminhão $\mathrm{K}_{4}($ carga + descarga + demoras $)=54^{\prime}+28^{\prime}+25^{\prime}=107^{\prime}$.

Tct (minutos) $=$ tempo de carga + tempo de descarga + tempo de demoras + tempo efetivo de viagem.

Fica faltando calcular em separado e acrescentar o tempo efetivo de viagem (ida e volta) por tipo de caminhão, que depende da velocidade média das viagens com e sem carga, da distância percorrida na rota e das condições de estradas.

As condições de estrada, conforme já mencionado, não são consideradas como restrições ao tráfego para nenhum dos quatro tipos de caminhão. O tempo efetivo de viagem transcorrido nas rodovias é função direta da distância a ser percorrida nas rotas e função inversa da velocidade média desenvolvida pelos caminhões.

Ao manter constante os tempos de carga, descarga e de demoras por tipo de caminhão, o tempo efetivo de viagem fica variando apenas em função das distâncias percorridas e das velocidades médias dos caminhões. Assim, são eliminadas do modelo as diferenças de eficiência operacional e organizacional existentes entre diferentes equipes de trabalho e entre indústrias. Portanto, os resultados obtidos por rota são decorrentes das diferenças de características dos tipos de caminhão utilizados no 
transporte, uma vez que o modelo mede o comportamento dos custos em função apenas das distâncias percorridas no transporte principal.

Adotam-se os valores de velocidade média obtidos por Seixas (1992) para os caminhões no transporte principal de madeira, na condição de estrada pavimentada.

$$
\begin{aligned}
& \text { Velocidade média do caminhão } K_{1}=53 \mathrm{~km} / \mathrm{h} \\
& \text { Velocidade média do caminhão } K_{2}=55 \mathrm{~km} / \mathrm{h} \\
& \text { Velocidade média do caminhão } K_{3}=50 \mathrm{~km} / \mathrm{h} \\
& \text { Velocidade média do caminhão } K_{4}=42,5 \mathrm{~km} / \mathrm{h}
\end{aligned}
$$

Calcula-se o tempo efetivo de viagem em função da velocidade média do caminhão "k", que é mantida constante para todas as rotas e todas as indústrias, e da distância que consta na rota da indústria "j".

Considerando o tempo de ciclo de transporte (Tct) e a jornada diária de trabalho no recebimento da madeira no pátio da indústria, obtém-se o último dado desconhecido para calcular " $\mathrm{Km}_{\mathrm{ijk}}$ ": o número de viagens ou de ciclos de transporte possíveis de serem efetuados por dia útil.

Uma vez concluídos os cálculos dos custos teóricos totais mensais de transporte principal $\left(\mathrm{C}_{\mathrm{ijk} 1}, \mathrm{C}_{\mathrm{ijk} 2}, \mathrm{C}_{\mathrm{ijk} 3}\right.$ e $\left.\mathrm{C}_{\mathrm{ijk} 4}\right)$, divide-se cada um deles pela quantidade total $\left(t_{k}\right)$ de madeira transportada por cada um dos tipos de caminhão durante o mês $\left(t_{k}=\right.$ $\mathrm{n}^{\circ}$ de viagens mensais do caminhão $\mathrm{k} x \mathrm{CCk}$ ). O resultado é o custo de uma tonelada de madeira por tipo de caminhão por rota posta fábrica $\left(\mathrm{Ct}_{\mathrm{ijk}}\right)$, que é o parâmetro utilizado para efetuar os cálculos comparativos.

Dispondo dos valores de custos teóricos calculados em reais por tonelada de madeira posta fábrica $\left(\mathrm{Ct}_{\mathrm{ijk} 1}, \mathrm{Ct}_{\mathrm{ijk} 2}, \mathrm{Ct}_{\mathrm{ijk} 3} \mathrm{e} \mathrm{Ct}_{\mathrm{ijk} 4}\right)$ e supondo que o caminhão representativo da frota para a indústria "j" seja o " $\mathrm{K}_{1}$ ", por regra de três simples, tendo como referencial o custo $\mathrm{Ct}_{\mathrm{ijk}}$, verifica-se a equivalência percentual dos demais custos $\mathrm{Ct}_{\mathrm{ijk} 2}, \mathrm{Ct}_{\mathrm{ijk} 3}$ e $\mathrm{Ct}_{\mathrm{ijk} 4}$. Esta equivalência calculada para cada tipo de caminhão, para cada rota, é o denominado "fator de correção" $\left(\mathrm{f}_{\mathrm{ijk}}\right)$ utilizado para estimar os coeficientes de custos "B $\mathrm{Bijk}_{\mathrm{j}}$ da Tabela 17. 
Para o procedimento desta série de cálculos referentes à obtenção dos custos $\left(\mathrm{Ct}_{\mathrm{ijk}}\right)$ e dos fatores de correção $\left(\mathrm{f}_{\mathrm{ijk}}\right)$, de maneira a reduzir o tempo consumido e minimizar a possibilidade de ocorrência de erros, montou-se todas as sequiências descritas em 6.4.3, 6.4.4 e 6.4.5, em um programa de automação de cálculo tendo como variável de entrada as distâncias da Tabela 13 e como resultado final os "fatores de correção" por rota e por caminhão.

\subsubsection{Formulação matemática do Modelo II}

Dispondo das informações contidas na Tabela 17 (R\$/viagem/rota/tipo de caminhão), das capacidades de carga definidas para cada tipo de caminhão considerado e das restrições de demandas e de ofertas já caracterizadas, chega-se ao seguinte modelo para o período de um ano:

Minimizar $Z=\sum_{i=1}^{32} \sum_{j=1}^{6} \sum_{k=1}^{4} B_{\mathrm{ijk}} \mathrm{q}_{\mathrm{ijk}}$

Sujeito a:

$$
\begin{aligned}
& \sum_{i=1}^{32} \sum_{k=1}^{4} \mathrm{CC}_{\mathrm{k}} \mathrm{q}_{\mathrm{ijk}} \geq \mathrm{Dj} \quad \mathrm{p} / \mathrm{j}=1 \text { a } 6 \\
& \sum_{j=1}^{6} \sum_{k=1}^{4} \mathrm{CC}_{\mathrm{k}} \mathrm{q}_{\mathrm{ijk}} \leq \mathrm{Oi} \quad \mathrm{p} / \mathrm{i}=1 \text { a } 32 \\
& \mathrm{q}_{\mathrm{ijk}} \geq 0
\end{aligned}
$$

Onde:

$Z=$ custo total do transporte principal de toras de eucalipto em reais $(R \$)$;

$\mathrm{B}_{\mathrm{ijk}}=$ coeficientes da Tabela 17, em R $\$ /$ viagem/rota "ij"/tipo "k" de caminhão;

$\mathrm{q}_{\mathrm{ijk}}=$ número de viagens realizadas na rota "ij" usando o caminhão do tipo "k";

$\mathrm{CC}_{\mathrm{k} 1}=13,8 \mathrm{t} . /$ viagem

$\mathrm{CC}_{\mathrm{k} 2}=26,6 \mathrm{t} . / \mathrm{viagem}$ 
$\mathrm{CC}_{\mathrm{k} 3}=28,8 \mathrm{t} . / \mathrm{viagem}$

$\mathrm{CC}_{\mathrm{k} 4}=49,9 \mathrm{t} . / \mathrm{viagem}$

$\mathrm{m}=32$

$\mathrm{n}=6$

$l=4$

$\mathrm{CC}_{\mathrm{k}} \mathrm{q}_{\mathrm{ijk}}=$ (t./viagem/tipo " $\mathrm{k}$ " de caminhão) $\mathrm{x}$ ( $\mathrm{n}^{\mathrm{o}}$ de viagens/tipo " $\mathrm{k}$ " de caminhão na rota "ij") = toneladas de toras curtas de eucalipto transportadas na rota "ij" pelo caminhão "k"

\subsubsection{Pressuposições e limitações do Modelo II}

Além de assumir as limitações e pressuposições do modelo I que lhe são pertinentes, algumas outras devem ser acrescentadas:

- O elenco de tipos de caminhão é restrito aos quatro considerados com sendo predominantes nas frotas das seis indústrias, porém a disponibilidade de tipos de caminhão no mercado é muito maior.

- A estimativa do número de viagens realizadas não leva em consideração as peculiaridades ou diferenças de eficiência das equipes e das indústrias.

- Não foram especificados no cálculo dos custos de transporte os seguintes itens: qualidade das estradas, efeitos das variações climáticas, limitações técnicas das estradas para tráfego dos diferentes tipos de caminhão, existência ou não de pedágios ou balanças, operações de carga e descarga, manutenção, reparos, tempo de manobras e tempo de filas.

\subsection{Modelo de transporte individualizado com várias origens e um único destino, sem definição do tipo de caminhão (Modelo III)}

Esta modelagem é basicamente idêntica a do Modelo I, com os mesmos objetivos, as mesmas variáveis de decisão, as mesmas restrições, utilizando-se a mesma 
terminologia e a mesma base de dados contidos na Tabela 14. Desta vez, entretanto, elimina-se a competição por fontes de abastecimento entre as indústrias, considerando-as no modelo uma a uma separadamente, mantendo-se inalteradas as demandas individuais e as capacidades de ofertas.

Surge neste caso um problema de transporte com várias fontes de abastecimento (32 origens) e um único destino. (Figura 6). Considerando-se as seis indústrias individualmente, foram gerados seis problemas de minimização do custo de transporte. Isto significa que o mesmo modelo é aplicado seis vezes alterando-se apenas o destino "j" da madeira, gerando-se seis modelos individualizados e seis soluções ótimas, uma para cada indústria.

Os dados para cada modelo individual estão na matriz dos coeficientes de custos de transporte da tabela 14. Cada uma das colunas de $\mathrm{j}=1$ a $\mathrm{j}=6$ refere-se a uma indústria, bastando considerar os vetores "cij" no formato $32 \times 1$ para j variando de 1 a 6 que teremos a base de dados que abastece os seus respectivos modelos matemáticos de otimização individual. Por exemplo, o vetor "ci1", para "i" variando de 1 a 32, é a base de dados para a Champion Papel e Celulose.

A solução ótima dos modelos permite que se conheça o potencial de cada uma das indústrias na condição teórica de atuar sozinha no mercado, definindo rotas segundo o custo mínimo de transporte sem contar com a concorrência na demanda por fonte de abastecimento. Os resultados com base nas soluções ótimas estabelecem limites potenciais para os possíveis ganhos de eficiências, segundo as condições existentes.

Apesar de teórica, esta situação é muito útil como referencial na condição de cada indústria individualmente. Outra observação a ser feita é que as soluções ótimas do Modelo III só podem ser comparadas com as situações individuais no transporte realizado em 1996 (Realizado) ou com as soluções ótimas individuais do Modelo I. 
Indústria $\quad$ Origens

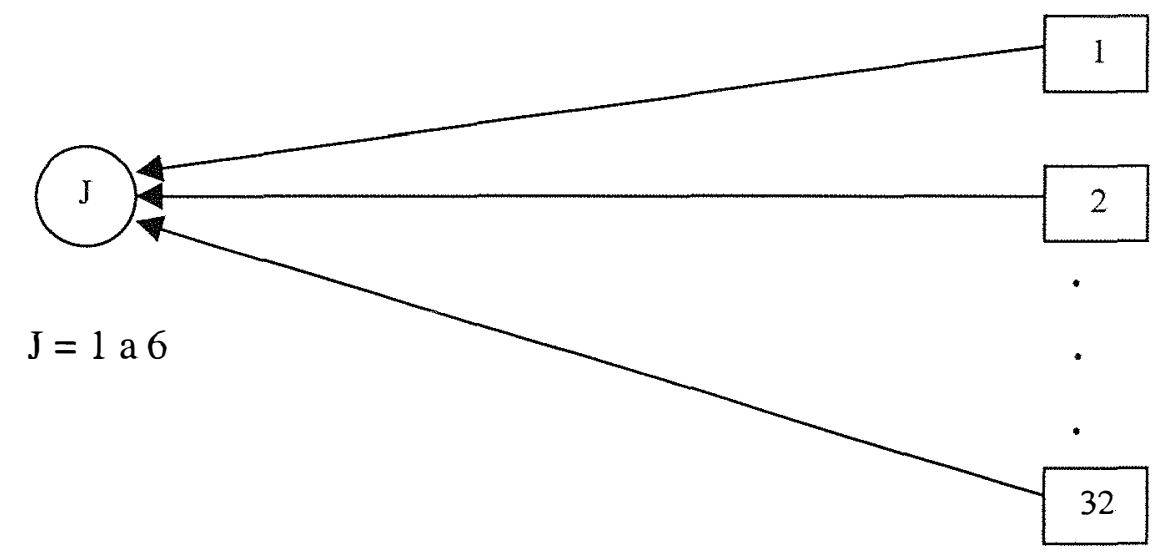

Figura 6 - Representação gráfica do problema de transporte com várias origens e um único destino.

\subsubsection{Formulação teórica do Modelo III}

Função objetivo : $\mathrm{Z}=\sum_{i=1}^{m} \mathrm{Cij} \mathrm{Xij} \quad \mathrm{p} / \mathrm{j}=1$ a $n$

Minimizar Z sujeito a :

$$
\begin{array}{ll}
\sum_{i=1}^{m} \mathrm{Xij} \geq \mathrm{Dj} ; & \mathrm{j}=1 \text { a } n \\
\mathrm{Xij} \leq \mathrm{Oi} ; & \mathrm{p} / \mathrm{i}=1 \text { a } m \\
\mathrm{Xij} \geq 0 &
\end{array}
$$


Onde:

$\mathrm{Z}$ = custo total de transporte das toras curtas de eucalipto, para a indústria "j" (R\$);

$\mathrm{Cij}=$ custo de transporte de uma tonelada de toras de eucalipto na rota que vai da fazenda "i" até a indústria "j" (R \$/t./ij);

$\mathrm{Xij}$ = quantidade de toras de eucalipto transportadas na rota que une a fazenda "i" à indústria "j" (toneladas/ano);

$\mathrm{m}=$ número de fazendas fornecedoras de madeira;

$\mathrm{n}=$ identificação da indústria para a qual se aplica o modelo, segundo a Tabela 14;

$\mathrm{Dj}$ = total anual em toneladas de toras curtas de eucalipto demandadas pela indústria "j";

$\mathrm{Oi}$ = quantidade anual em toneladas de toras curtas de eucalipto ofertadas por cada uma das "i" fazendas de origem.

\subsubsection{Formulação matemática do Modelo III}

Tomando como exemplo a indústria $\mathrm{j}=1$ da Tabela 14, tem-se:

Função objetivo : $\mathrm{Z}=\sum_{i=1}^{32} \mathrm{C}_{\mathrm{i} 1} \mathrm{X}_{\mathrm{i} 1}$

Minimizar $Z$ sujeito a :

$$
\begin{array}{ll}
\sum_{i=1}^{32} X_{i 1} \geq 1.147 .111 \mathrm{t} . \\
X_{\mathrm{i} 1} \leq \mathrm{O}_{\mathrm{i}} & \mathrm{p} / \mathrm{i}=1 \text { a } 32 \\
\mathrm{X}_{\mathrm{i} 1} \geq 0 &
\end{array}
$$

As pressuposições e limitações deste modelo são as mesmas que se aplicam ao Modelo I, acrescentando-se a observação do caráter puramente teórico do modelo. 


\section{RESULTADOS E DISCUSSÃO}

Neste capítulo são apresentados e discutidos os resultados obtidos com a solução ótima dos diferentes modelos econômicos de transporte, basicamente através de comparações dos modelos I e II com os valores do transporte principal realizado (Realizado) pelas indústrias no ano de 1996.

Com os resultados são construídas quatro tabelas utilizando-se unidades e parâmetros de medidas comuns a todas elas, exceto para a tabela do transporte realizado onde não consta as duas colunas referentes a rotas de terceiros.

O termo "terceiros" em algumas tabelas é utilizado para designar fazendas ou origens da madeira que não pertençam originariamente ao mesmo grupo empresarial da indústria que está sendo abastecida. As colunas com " $\Delta \%$ " indicam percentual de variação na vertical ou entre modelos, no caso deste estudo a referência é sempre o Realizado. As colunas com "\%" indicam variações percentuais dentro de um mesmo modelo ou variações em linha.

As tabelas obtidas são as seguintes:

- Tabela 18 para o transporte realizado (Realizado);

- Tabela 19 mostra os resultados da solução ótima do Modelo I;

- Tabela 20 para os resultados da solução ótima do Modelo II;

- Tabela 21 com os resultados de otimização dos modelos individuais (Modelo III).

Apesar de se desconsiderar teoricamente os vínculos de propriedade entre indústrias e povoamentos florestais, é necessário que as notações (letras e números) utilizadas nas colunas "Rotas" das tabelas permitam que se identifique as origens da madeira na listagem de resultados das soluções ótimas dos modelos. 


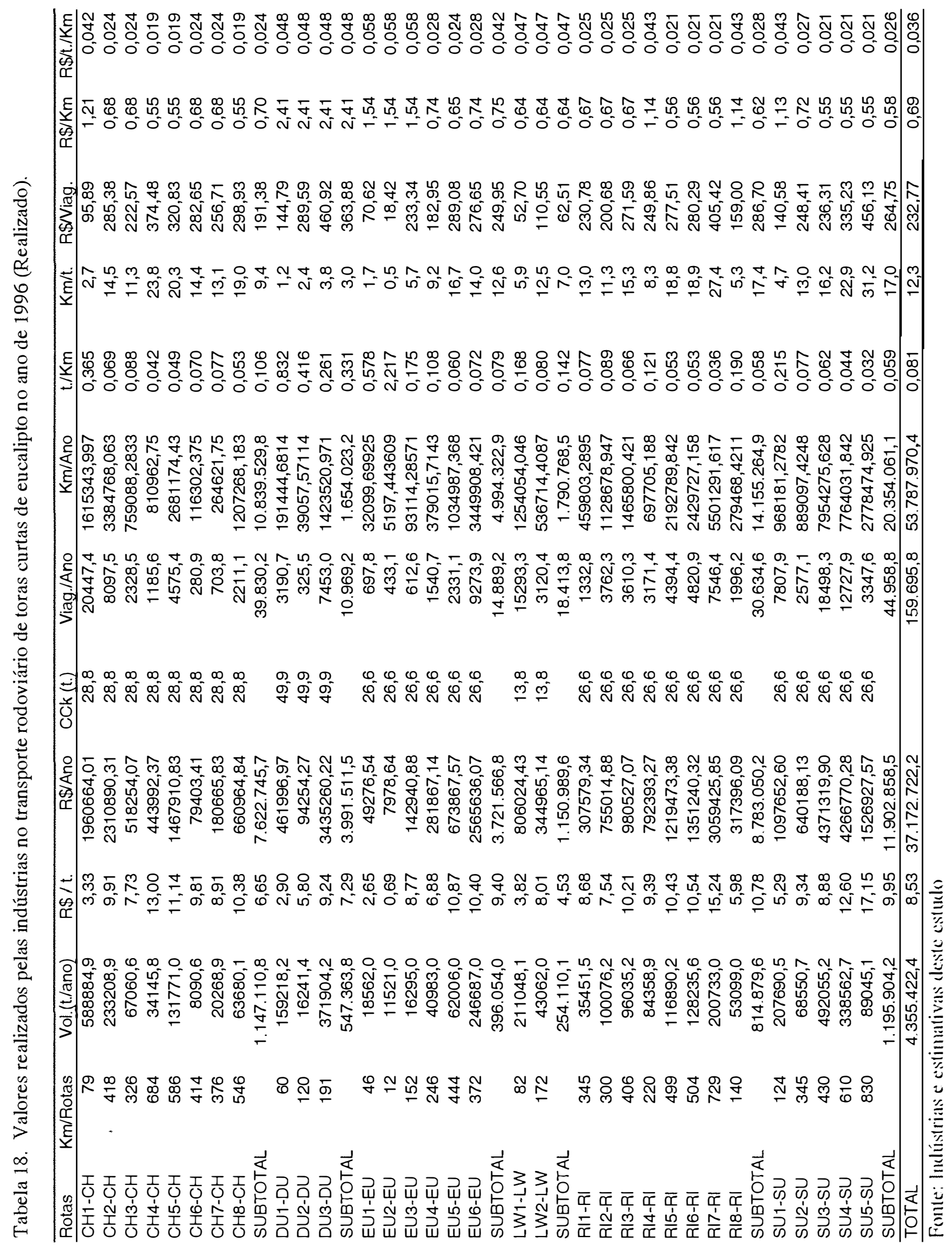


Através da coluna Rotas é possível identificar e quantificar diretamente as ocorrências de trocas de fontes de abastecimento entre as indústrias, decorrentes das aplicações dos modelos e, por correlação, fazer inferências quanto a essas trocas em termos de quilometragem e volume.

A coluna "quilômetros por rotas ( $\mathrm{km} / \mathrm{rotas})$ " refere-se aos valores que constam na Tabela 13. Os volumes em toneladas anuais transportadas em cada rota "Vol.(t./ano)" - são valores fornecidos pela otimização dos modelos, exceto para a Tabela 18. As colunas de custos da tonelada de madeira transportada ( $\mathrm{R} \$ \mathrm{t}$.) se referem aos valores dos fretes que constam na Tabela 14, exceto para a Tabela 20 onde se utiliza os valores da Tabela 16.

Os custos anuais de transporte por rota (R/ano) são resultados de estimativas feitas utilizando-se as colunas de volume transportado "Vol.(t./Ano)" e de custo de transporte $(\mathrm{R} \$ / \mathrm{t}$.).

A coluna de capacidade de carga $\left(\mathrm{CC}_{\mathrm{k}}\right)$, além de participar dos cálculos de volume, é útil na identificação do tipo de caminhão usado pelas indústrias no transporte principal em cada uma das rotas. Os tipos de caminhão adotados pelas indústrias e o número de viagens realizadas por ano (Viag./Ano) se mantêm o mesmo para todas as tabelas, exceto para a Tabela 20. Nesta tabela, o conteúdo da coluna $\mathrm{CC}_{\mathrm{k}}$ é resultado da solução ótima do Modelo II, o que modifica também os resultados da coluna "Viag/Ano" e os resultados da coluna de quilômetros anualmente percorridos ( $\mathrm{Km} / \mathrm{Ano})$.

A intensidade de uso das rotas no transporte principal (tráfego) pode ser medida pelo número médio de viagens transcorridas anualmente em cada uma delas (Viagens/ Ano) e pelo total de quilômetros percorridos anualmente (Km/Ano).

As demais colunas se referem a toneladas por quilômetro percorrido (t./Km), quilômetros por tonelada de madeira posta fábrica $(\mathrm{Km} / \mathrm{t}$.), custo médio por viagem ( $\mathrm{R} \$ /$ Viag.), custo médio do quilômetro percorrido $(\mathrm{R} \$ / \mathrm{Km})$ e custo médio por tonelada por quilômetro $(\mathrm{R} \$ / \mathrm{t} . / \mathrm{Km})$. 


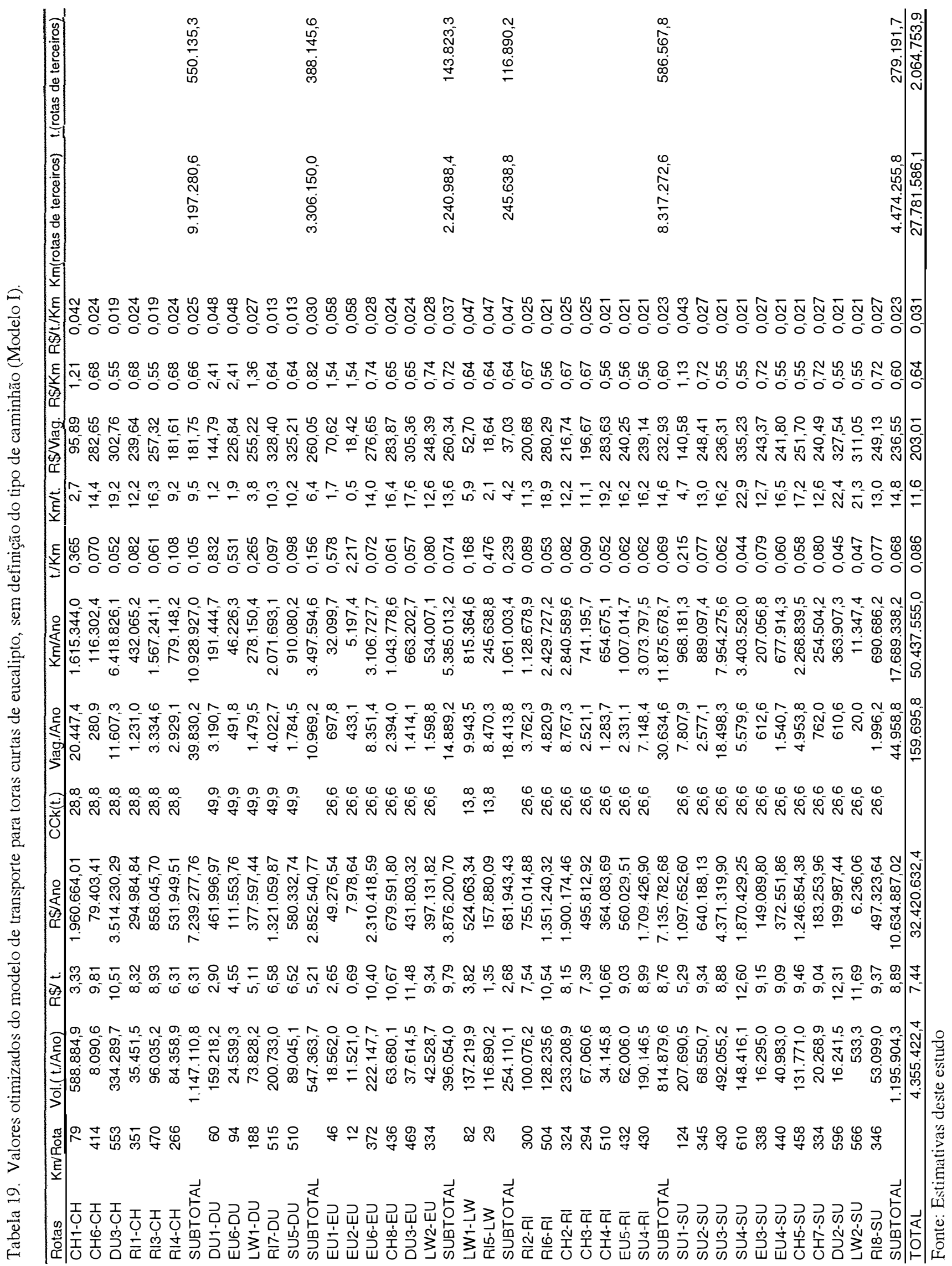


A coluna de reais por tonelada por quilômetro $(\mathrm{R} \$ / \mathrm{t} . / \mathrm{Km})$ define os custos segundo a rota específica e a distância de seu percurso de ida e volta, perfazendo um ciclo completo do transporte principal (Km/rota). É a distância de percurso necessária de ser percorrida para entregar o volume de uma única tonelada de madeira que se dá em um único ciclo de transporte principal, uma vez que a capacidade de carga dos caminhões excede uma tonelada. Devido a esta característica, a coluna de $\mathrm{R} \$ / \mathrm{t}$./Km é a única que apresenta o valor médio no "subtotal" obtido por cálculo em coluna e não em linha como as demais.

A utilização do termo "subtotal" em todas as tabelas serve para separar e identificar os blocos referentes à cada uma das indústrias, além de permitir a totalização parcial de valores e obtenção de médias para efeito de comparações. Os valores em "total" na última linha caracterizam o "sistema" agregado das indústrias, para efeito de comparação entre os totais das Tabelas 18,19 e 20.

A primeira das quatro tabelas (Tabela 18) apresenta dados de levantamentos e estimativas para as condições em que ocorre o transporte principal praticado pelas indústrias (Realizado). Com base em dados e informações levantadas junto às indústrias (colunas 1, 3 e 6) e nas Tabelas 13 e 14 (colunas 2 e 4), procede-se a estimativa dos valores componentes das demais colunas.

As colunas "Rotas", "Vol.(t./Ano)" e "t./rotas de terceiros" da Tabela 19 são compostas de dados e informações obtidos na solução ótima do Modelo I. A identificação das indústrias é feita pelo agrupamento de rotas de destino comum. Observando-se o conteúdo da primeira coluna das tabelas dos modelos de solução ótima, fica evidente a ocorrência de trocas de fontes de abastecimento (fazendas) na composição das rotas. Nota-se que todas as indústrias participam do processo de trocas de fontes de abastecimento e o aspecto quantitativo destas participações em termos de quilômetros percorridos e toneladas transportadas pode ser verificado nas duas últimas colunas da tabela.

Os subtotais da coluna "Vol.(t./Ano)" devem conferir com as demandas anuais de matéria-prima madeira definidas por cada uma das indústrias e impostas como restrições dentro dos modelos. 


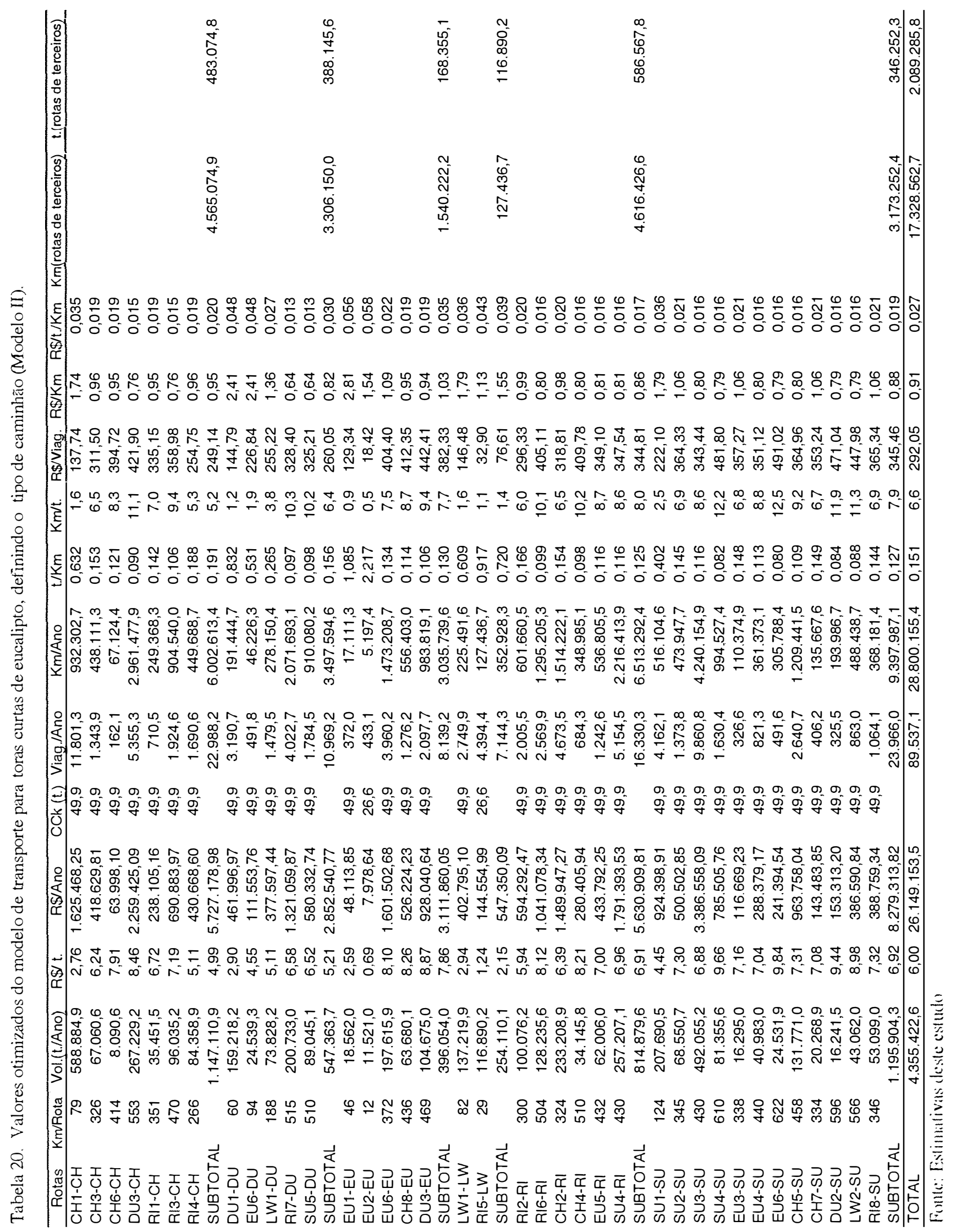


A Tabela 20 mantém a mesma estrutura da Tabela 19, porém com algumas alterações no que diz respeito à origem dos dados que compõem algumas das colunas. A primeira, a sexta e a sétima colunas, a partir da esquerda, são compostas de dados obtidos diretamente nos resultados da solução ótima do Modelo II.

Os valores da coluna de custos por tonelada transportada (R $\$ / \mathrm{t}$.) e quilômetros por rota (Km/Rota) são obtidos na Tabela 13 e Tabela 16 respectivamente. As demais colunas são resultados de estimativas feitas através de operações dentro da tabela.

A Tabela 21 é idêntica à Tabela 19 no seu formato, na origem dos dados e das informações, porém com duas diferenças.

A primeira é que na coluna "Rotas", no lugar dos subtotais, encontra-se a referência ao Modelo III para cada uma das indústrias indicando uma situação de tratamento individualizado.

A segunda diferença é que apesar de termos na Tabela 21 uma série de somatórios, eles são meramente informativos uma vez que jamais serão atingidos, pois as condições de otimização de cada um dos "Modelo III" são mutuamente excludentes, não fazendo sentido a existência de subtotais.

Apesar desta forte limitação para o modelo III, ele continua tendo sua importância como referencial, pois seus resultados de soluções ótimas ocorrem dentro de uma condição extremamente favorável para as industrias no que diz respeito a aquisição e transporte de matéria prima madeira.

Conforme dito anteriormente, as condições individuais definidas pelos diversos "Modelos III" estabelecem o limite do ótimo para cada uma das indústrias individualmente dentro das condições estabelecidas, definindo-se assim um potencial máximo que passa a ser utilizado como referência na análise das indústrias dentro e fora do sistema, permitindo inferências quanto aos índices de troca e de eficiência. Por reunirem condições idênticas de cenário, os resultados de solução ótima dos modelos individuais de otimização (Modelo III) só podem ser comparados com os resultados individuais do modelo I e com os resultados individuais do transporte realizado pelas indústrias (Realizado). 


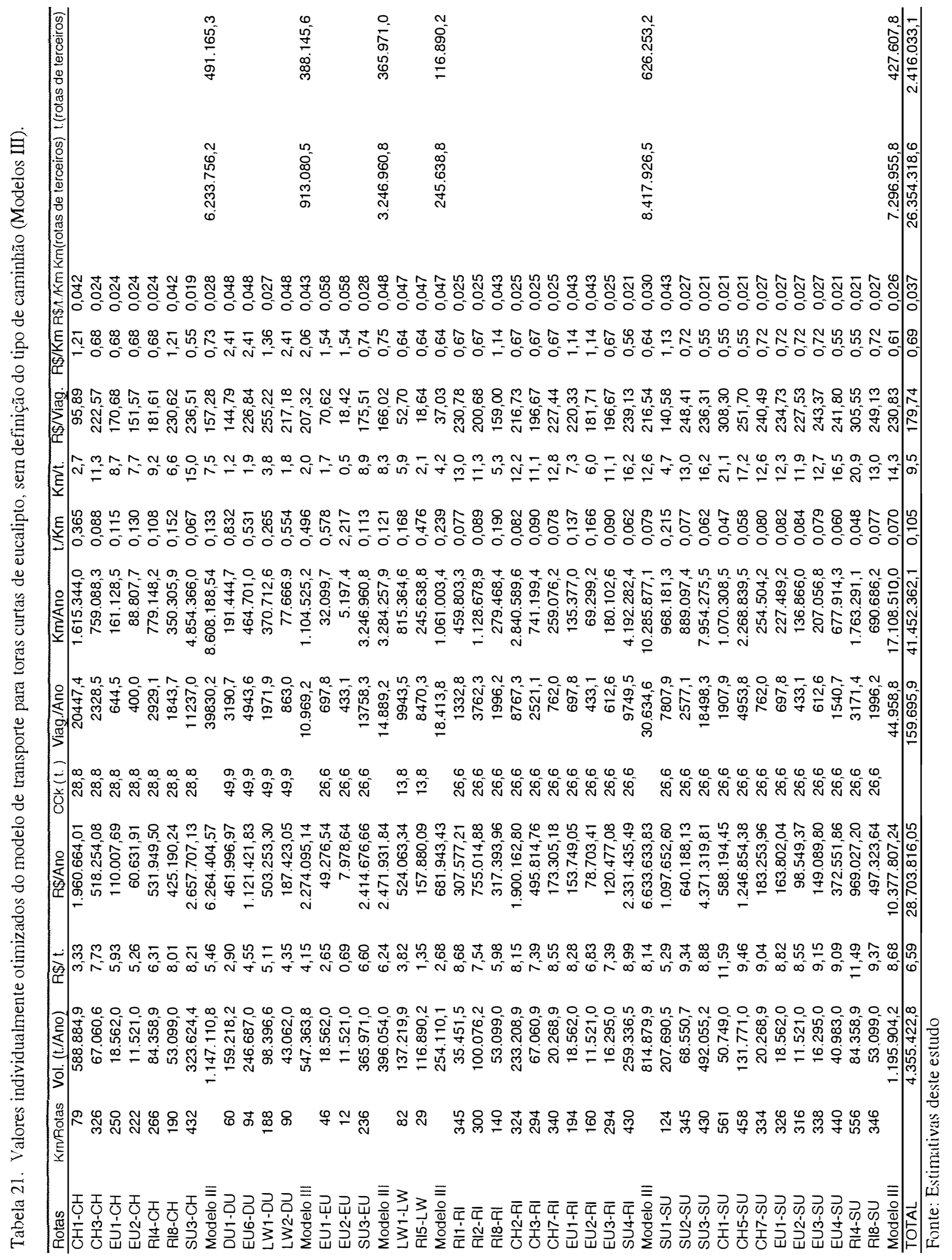


A coluna "Rotas" da Tabela 21 torna possível a identificação das fazendas selecionadas para participarem do abastecimento das diferentes indústrias. Como o modelo disponibiliza sempre o mesmo elenco de fazendas para proceder todas as seis otimizações em separado, pode-se verificar a freqüência de participação das fazendas nas diversas soluções ótimas tanto como fornecedoras assíduas como excluídas.

A análise dos resultados obtidos na otimização dos modelos é organizada e conduzida de maneira a abordar primeiramente a perspectiva de "sistema" constituído do agregado das indústrias (7.1 a 7.4) e em seguida a abordagem do comportamento individual das indústrias desmembrando-as do agregado (7.5 a 7.11).

Para facilitar o trabalho de análise e comparação dos resultados, as informações contidas nas quatro tabelas foram resumidas e organizadas em três outras tabelas abordando três aspectos distintos, a saber:

1) as relações de trocas entre as indústrias (qualitativa e quantitativa),

2) os aspectos de custos do transporte principal (eficiência econômica) e

3) os aspectos de produção do transporte principal (eficiência operacional).

Temos, portanto, três abordagens a serem feitas. A primeira, com base na Tabela 22, considera o aspecto das trocas de fontes de abastecimento (fazendas ou origens). Apesar da quebra do vínculo de propriedade, as origens continuam sendo identificadas segundo a indústria a que pertencem, permitindo identificá-las quando interagem nestas trocas.

A segunda abordagem dentro do aspecto de eficiência econômica utiliza a Tabela 23 para comparar os diferentes cenários segundo seus custos totais anuais $(\mathrm{R} \$ / \mathrm{ano})$ e custos da tonelada de madeira posta fábrica $(\mathrm{R} \$ / \mathrm{t}$.).

A terceira abordagem diz respeito à eficiência operacional do transporte principal (Tabela 24) medida em termos de quilometragem total percorrida no ano, quilometragem contida em uma tonelada de madeira posta fábrica $(\mathrm{km} / \mathrm{t}$.) e número de viagens realizadas anualmente. 
A contribuição individual de cada modelo pode ser medida pela eficiência operacional (Tabela 23) e pela eficiência econômica (Tabela 24), utilizando-se alguns parâmetros tomados como referência.

No caso da eficiência econômica, avalia-se a realização da tarefa de abastecimento que atende à demanda anual de madeira do sistema ou das indústrias individualmente, segundo o custo total de transporte principal ( $\mathrm{R} \$ \mathrm{ano})$ e segundo o custo da tonelada de madeira posta fábrica $(\mathrm{R} \$ / \mathrm{t}$.). No caso da eficiência operacional, mede-se a realização da mesma tarefa de abastecimento industrial, segundo o total de quilômetros anualmente percorridos $(\mathrm{km} / \mathrm{ano})$, de acordo com a quilometragem por tonelada de madeira posta fábrica $(\mathrm{km} / \mathrm{t}$.) ou ainda pelo número de viagens necessárias para o abastecimento (viagens/ano).

Deve-se levar em consideração ainda o fato de que todos os quatro sistemas obedecem a critérios prévios de planejamento (variáveis exógenas) quais sejam cumprir a tarefa de abastecimento fixado pelas indústrias para o período de um ano, definindo fazendas, povoamentos e quantidades (quanto e onde).

Para três dos modelos é mantido constante o tipo de caminhão utilizado por cada uma das indústrias no transporte principal. Conseqüentemente, mantém-se inalterado o número de viagens anualmente realizadas (função da demanda total anual de madeira e da capacidade de carga do caminhão), alterando-se apenas para o modelo em que se insere a opção "tipo de caminhão" (Modelo II).

Existem outros efeitos indiretos decorrentes de ganhos de eficiência operacional ( $\mathrm{Km} / \mathrm{ano}$ ) e decorrentes de uma menor intensidade de uso da rede rodoviária que não são objetos de estudo deste trabalho, porém devido à estreita ligação com os resultados obtidos merecem ser lembrados, como por exemplo, redução nos custos sociais decorrentes da redução do número de acidentes, redução de gastos com seguros, gastos hospitalares, dias paralisados, gastos com manutenção de máquinas e equipamentos; redução em manutenção de rodovias e emissão de gases de efeito estufa (GEE) pelos motores a explosão, principalmente $\mathrm{CO}_{2}$. 


\subsection{Transporte realizado (Realizado) versus solução ótima do Modelo I}

Esta comparação avalia principalmente os ganhos para o sistema advindos da suposta quebra do vínculo de propriedade entre povoamento e indústria. O intercâmbio de madeira resultante da solução ótima do modelo I promove uma nítida alteração na redistribuição final das fazendas. Mais da metade das rotas anteriormente realizadas (65\%) é trocada por rotas com origem em fazendas de terceiros que respondem por quase metade do volume total de madeira transportada $(47,4 \%)$.

O número de rotas utilizadas passa de 32 no Realizado para 37 no modelo I, significando que com a solução ótima do modelo I algumas fazendas abastecem mais de uma indústria. É o caso das fazendas $\mathrm{EU}_{6}, \mathrm{SU}_{4}, \mathrm{LW}_{1}, \mathrm{LW}_{2}$ e $\mathrm{DU}_{3}$ que atendem às seguintes rotas: $\mathrm{EU}_{6}-\mathrm{EU}, \mathrm{EU}_{6}-\mathrm{DU}, \mathrm{LW}_{1}-\mathrm{LW}, \mathrm{LW}_{1}-\mathrm{DU}, \mathrm{SU}_{4}-\mathrm{SU}, \mathrm{SU} 4-\mathrm{RI}, \mathrm{LW}_{2}$ EU, $\mathrm{LW}_{2}-\mathrm{SU}, \mathrm{DU}_{3}-\mathrm{CH}$ e $\mathrm{DU}_{3}-\mathrm{EU}$. A fazenda $\mathrm{EU}_{6}$ da Ecucatex tem sua capacidade de oferta anual de madeira de 246.687 t. repartida entre a sua própria fábrica e a da Duratex; o mesmo ocorrendo com as fazendas $\mathrm{LW}_{1}(211.048,1 \mathrm{t}$.) que atendem à própria demanda e à da Duratex; e com a fazenda $\mathrm{SU}_{4}(338.562,7$ t.) que atende à própria demanda e à da Ripasa. As fazendas $\mathrm{LW}_{2}\left(43.062\right.$ t.) e $\mathrm{DU}_{3}$ (371.904 t.) têm suas capacidades anuais de oferta totalmente comprometidas e direcionadas para atender exclusivamente às fazendas de terceiros.

Analisando por sistema, o que se pode afirmar é que na condição de ótimo de custo de transporte, todas as seis indústrias participam do processo de trocas no abastecimento. O percentual de trocas observado varia de um mínimo de 50\% a um máximo de $80 \%$ das fazendas próprias para as de terceiros. Quem troca com quem e em que intensidade ocorre fica mais evidente na análise por indústria.

A redução observada nos custos totais anuais devido à otimização do sistema é de $12,8 \%$ ( $\mathrm{R} \$ 4.752 .090,00$ ), sem comprometer o abastecimento de nenhuma das indústrias envolvidas dentro do período de tempo considerado. 
Tabela 22. Número de origens (fazendas) por destino nas diferentes soluções apresentadas pelos modelos.

\begin{tabular}{|c|c|c|c|c|c|c|c|c|}
\hline \multirow{2}{*}{$\begin{array}{l}\text { Destinos } \\
\text { (Indúst.) }\end{array}$} & \multirow{2}{*}{$\begin{array}{l}\text { Sistema e } \\
\text { Modelos }\end{array}$} & \multicolumn{6}{|c|}{ Origens (Fazendas) } & \multirow{2}{*}{$\begin{array}{l}\text { Origens de } \\
\text { terceiros (\%) }\end{array}$} \\
\hline & & $\mathrm{CH}$ & $\overline{\mathrm{DU}}$ & $\overline{E U}$ & LW & RI & SU & \\
\hline \multirow{4}{*}{$\mathrm{CH}$} & Realizado & 8 & & & & & & 0 \\
\hline & Modelo I & 2 & 1 & & & 3 & & 66,6 \\
\hline & Modelo II & 3 & 1 & & & 3 & & 57,1 \\
\hline & Modelo III & 2 & & 2 & & 2 & 1 & 71,4 \\
\hline \multirow{4}{*}{ DU } & Realizado & & 3 & & & & & 0 \\
\hline & Modelo I & & 1 & 1 & 1 & 1 & 1 & 80 \\
\hline & Modelo II & & 1 & 1 & 1 & 1 & 1 & 80 \\
\hline & Modelo III & & 1 & 1 & 2 & & & 75 \\
\hline \multirow{4}{*}{ EU } & Realizado & & & 6 & & & & 0 \\
\hline & Modelo I & 1 & 1 & 3 & 1 & & & 50 \\
\hline & Modelo II & 1 & 1 & 3 & & & & 40 \\
\hline & Modelo III & & & 2 & & & 1 & 33,3 \\
\hline \multirow{4}{*}{ LW } & Realizado & & & & 2 & & & 0 \\
\hline & Modelo I & & & & 1 & 1 & & 50 \\
\hline & Modelo II & & & & 1 & 1 & & 50 \\
\hline & Modelo III & & & & 1 & 1 & & 50 \\
\hline \multirow{4}{*}{ RI } & Realizado & & & & & 8 & & 0 \\
\hline & Modelo I & 3 & & 1 & & 2 & 1 & 71,4 \\
\hline & Modelo II & 2 & & 1 & & 2 & 1 & 66,6 \\
\hline & Modelo III & 3 & & 3 & & 3 & 1 & 70 \\
\hline \multirow{4}{*}{ SU } & Realizado & & & & & & 5 & 0 \\
\hline & Modelo I & 2 & 1 & 2 & 1 & 1 & 4 & 63,6 \\
\hline & Modelo II & 2 & 1 & 2 & 1 & 1 & 4 & 66,6 \\
\hline & Modelo III & 3 & & 4 & & 2 & 3 & 75 \\
\hline \multirow{3}{*}{ Sistema } & Realizado & 8 & 3 & 6 & 2 & 8 & 5 & 0 \\
\hline & Modelo I & 8 & 4 & 7 & 4 & 8 & 6 & 64,9 \\
\hline & Modelo II & 8 & 4 & 8 & 3 & 8 & 6 & 62,1 \\
\hline
\end{tabular}

Fonte: Estimativas deste estudo 
Tabela 23. Desempenho econômico, medido pelo custo anual total e unitário de transporte, das diferentes soluções apresentadas pelos modelos.

\begin{tabular}{|c|c|c|c|c|c|c|c|c|}
\hline \multirow{2}{*}{\multicolumn{2}{|c|}{$\begin{array}{l}\text { Indústrias, Sistema e } \\
\text { Modelos }\end{array}$}} & \multicolumn{2}{|c|}{ Custos anuais } & \multirow{2}{*}{$\begin{array}{c}\mathrm{R} \$ \\
\text { / viagem }\end{array}$} & \multirow[t]{2}{*}{$\mathrm{R} \$ / \mathrm{Km}$} & \multicolumn{2}{|c|}{$\mathrm{R} \$ / \mathrm{t}$} & \multirow[t]{2}{*}{$\mathrm{R} \$ / \mathrm{t} / \mathrm{km}$} \\
\hline & & $\mathrm{R} \$$ & $\Delta(\%)$ & & & $\mathrm{RS}$ & $\Delta(\%)$ & \\
\hline \multirow{4}{*}{$\mathrm{CH}$} & Realizado & 7.622 .746 & 0 & 191,38 & 0,70 & 6,65 & 0 & 0,024 \\
\hline & Modelo I & 7.239.278 & $-5,0$ & 181,75 & 0,66 & 6,31 & $-5,0$ & 0,025 \\
\hline & Modelo II & 5.727 .179 & $-24,8$ & 249,14 & 0,95 & 4,99 & $-24,8$ & 0,020 \\
\hline & Modelo III & 6.264 .404 & $-17,8$ & 157,28 & 0,73 & 5,46 & $-17,8$ & 0,028 \\
\hline \multirow{4}{*}{ DU } & Realizado & 3.991 .511 & 0 & 363,88 & 2,41 & 7,29 & 0 & 0,048 \\
\hline & Modelo I & 2.852 .541 & $-28,5$ & 260,05 & 0,82 & 5,21 & $-28,5$ & 0,030 \\
\hline & Modelo II & 2.852 .541 & $-28,5$ & 260,05 & 0,82 & 5,21 & $-28,5$ & 0,030 \\
\hline & Modelo III & 2.274 .095 & $-43,0$ & 207,32 & 2,06 & 4,15 & $-43,0$ & 0,043 \\
\hline \multirow{4}{*}{ EU } & Realizado & 3.721 .567 & 0 & 249,95 & 0,75 & 9,40 & 0 & 0,042 \\
\hline & Modelo I & 3.876 .201 & 4,1 & 260,34 & 0,72 & 9,79 & 4,1 & 0,037 \\
\hline & Modelo II & 3.111 .860 & $-16,4$ & 382,33 & 1,03 & 7,86 & $-16,4$ & 0,035 \\
\hline & Modelo III & 2.471 .932 & $-33,5$ & 166,02 & 0,75 & 6,24 & $-33,5$ & 0,048 \\
\hline \multirow{4}{*}{ LW } & Realizado & 1.150 .989 & 0 & 62,51 & 0,64 & 4,53 & 0 & 0,047 \\
\hline & Modelo I & 681.943 & $-40,7$ & 37,03 & 0,64 & 2,68 & $-40,7$ & 0,047 \\
\hline & Modelo II & 547.350 & $-52,4$ & 76,61 & 1,55 & 2,15 & $-52,4$ & 0,039 \\
\hline & Modelo III & 681.943 & $-40,7$ & 37,03 & 0,64 & 2,68 & $-40,7$ & 0,047 \\
\hline \multirow{4}{*}{ RI } & Realizado & 8.783 .050 & 0 & 286,7 & 0,62 & 10,78 & 0 & 0,028 \\
\hline & Modelo I & 7.135 .783 & $-18,7$ & 232,93 & 0,60 & 8,76 & $-18,7$ & 0,023 \\
\hline & Modelo II & 5.630 .910 & $-35,9$ & 344,81 & 0,86 & 6,91 & $-35,9$ & 0,017 \\
\hline & Modelo III & 6.633 .634 & $-24,4$ & 216,54 & 0,64 & 8,14 & $-24,4$ & 0,030 \\
\hline \multirow{4}{*}{ SU } & Realizado & 11.902 .858 & 0 & 264,75 & 0,58 & 9,95 & 0 & 0,026 \\
\hline & Modelo I & 10.634 .887 & $-10,6$ & 236,55 & 0,60 & 8,89 & $-10,6$ & 0,025 \\
\hline & Modelo II & 8.279 .314 & $-30,4$ & 345,46 & 0,88 & 6,92 & $-30,4$ & 0,019 \\
\hline & Modelo III & 10.377 .807 & $-12,8$ & 230,83 & 0,61 & 8,68 & $-12,8$ & 0,026 \\
\hline \multirow{3}{*}{ Sistema } & Realizado & 37.172 .722 & 0 & 232,77 & 0,69 & 8,53 & 0 & 0,035 \\
\hline & Modelo I & 32.420 .632 & $-12,8$ & 203,01 & 0,64 & 7,44 & $-12,8$ & 0,030 \\
\hline & Modelo II & 26.149 .154 & $-29,6$ & 292,05 & 0,91 & 6,00 & $-29,6$ & 0,026 \\
\hline
\end{tabular}

Fonte: Estimativas deste estudo 
Esta redução nos custos totais de transporte de longa distância reflete nas mesmas proporções sobre os custos da tonelada de madeira posta fábrica ( $R \$ / t$.) e gera uma expectativa de redução de $1,28 \%$ nos custos do produto final, ampliando a margem de eficiência econômica com ganhos de competitividade via preço.

A importância do processo de trocas de fontes de abastecimento (fazendas) pode ser medida no modelo I pelo percentual de quilometragem anualmente percorrida em rotas que ligam indústrias a fazendas de terceiros $(55,1 \%)$. O número de viagens anuais necessárias para o abastecimento mantém-se o mesmo (159.696), apresentando uma redução de 3.350.415 quilômetros no total anual percorrido. Observa-se redução também na distância média por viagem $(\mathrm{km} /$ viagem) e na demanda de quilômetros por tonelada de madeira posta fábrica $(\mathrm{km} / \mathrm{t}$.). Estas reduções implicam em um ganho de eficiência operacional que gira em torno de $6 \%$, o que, considerando-se 300 dias úteis no ano, significa uma margem de folga de 18 dias no planejamento anual do transporte principal.

\subsection{Transporte realizado (Realizado) versus solução ótima do Modelo II}

Esta comparação além de manter a mesma condição teórica de quebra de vínculo de propriedade considerada anteriormente, permite que se faça opção de escolha pelo melhor veículo a ser usado no transporte principal de madeira em termos de custo mínimo.

A solução ótima do modelo modificado com a incorporação da variável "tipo de transporte", ao ser comparada com o sistema realizado (Realizado), redefine uma composição de rotas em que as trocas de origens representam $62,1 \%$ do total. A solução ótima define o tipo de caminhão $\mathrm{k}_{4}$ (49,9 t.) como melhor opção de transporte para todas as rotas, com exceção de $\mathrm{EU}_{2}-\mathrm{EU}$ e $\mathrm{RI}_{5}$ - LW com o tipo de caminhão k 2 (26,6t.). 


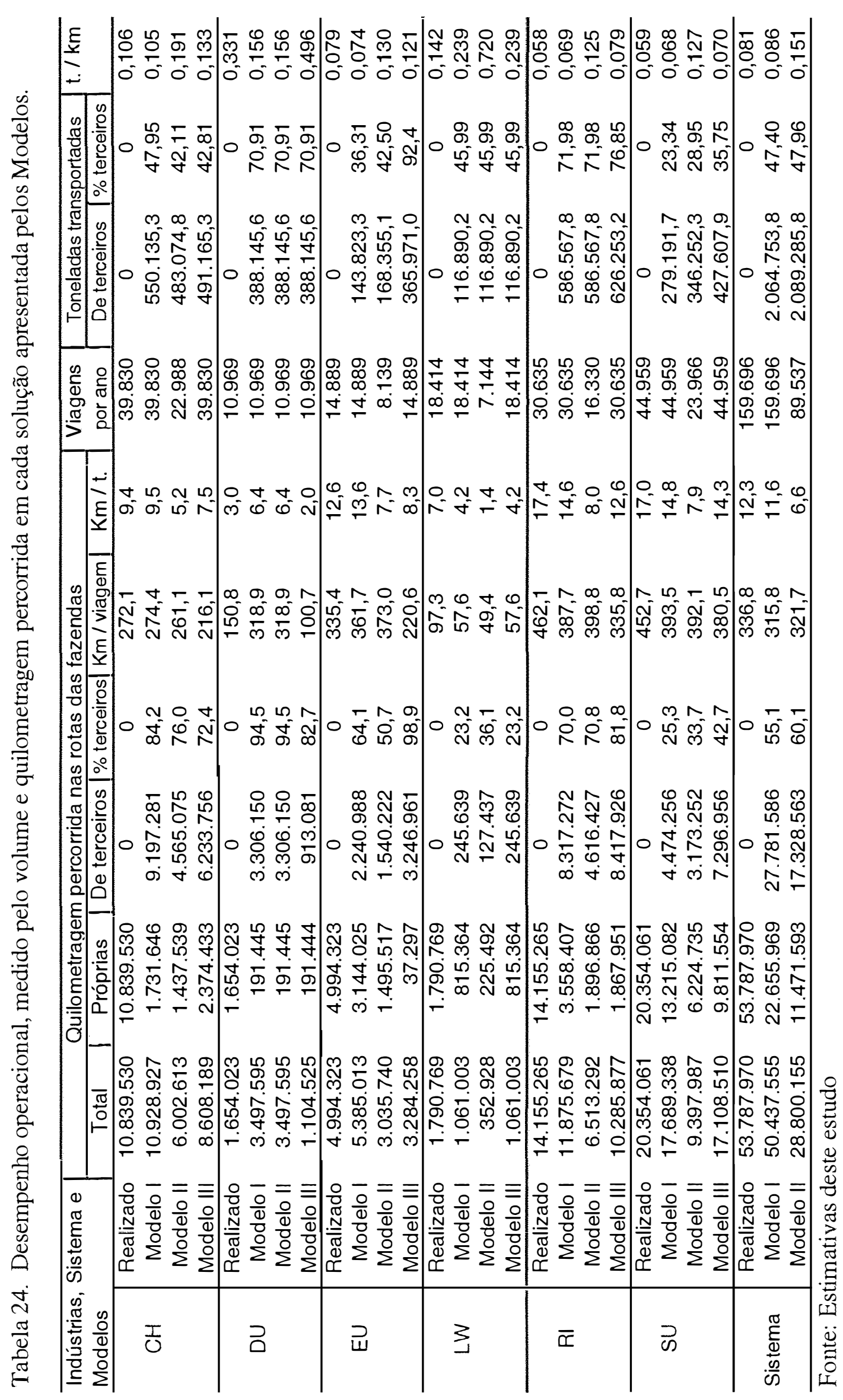


O número de rotas no Modelo $\Pi$ também passa das 32 originais para 37 onde uma fazenda abastece mais de uma indústria. Este é o caso das fazendas $E U_{6}, L_{1}, S_{4}$ e $\mathrm{DU}_{3}$ que atendem às rotas $\mathrm{EU}_{6}-\mathrm{EU}, \mathrm{EU}_{6}-\mathrm{DU}, \mathrm{EU}_{6}-\mathrm{SU}, \mathrm{LW}_{1}-\mathrm{LW}, \mathrm{LW}_{1}-\mathrm{DU}, \mathrm{SU}_{4}$ - SU, $S_{4}-\mathrm{RI}, \mathrm{DU}_{3}-\mathrm{CH}$ e $\mathrm{DU}_{3}-\mathrm{EU}$. Todas estas fazendas atendem à própria demanda anual e à de terceiros, exceção feita para a fazenda $\mathrm{DU}_{3}$, cuja capacidade produtiva é voltada exclusivamente para o atendimento de terceiros.

No modelo II todas as seis indústrias componentes do sistema participam em maior ou menor intensidade do processo de trocas de fontes de abastecimento, com índices que variam de 40 a $80 \%$.

A redução nos custos totais para o sistema é da ordem de $29,6 \%$ ( $R \$$ $11.023 .568,00)$ e para as indústrias varia entre $16,4 \%$ e $52,4 \%$. O valor da redução nos custos totais anuais para o sistema supera os gastos individuais com transporte principal de madeira de cinco das seis indústrias e praticamente se iguala $(92,7 \%)$ aos gastos praticados pela maior delas.

Há elevações de 26,4\% nos custos por viagem (R \$/viagem) e de 31,8\% nos custos por quilometro $(\mathrm{R} \$ / \mathrm{km})$ decorrentes de um aumento de distância na rota média e da adoção predominante do tipo de caminhão $k_{4}$ que, comparativamente aos outros tipos de caminhão, apresenta custos maiores. Porém, quando se considera a consequiência da maior capacidade de carga do caminhão $k_{4}$, verifica-se uma redução de 29,6\% nos custos da tonelada de toras curtas de eucalipto posta fábrica $(\mathrm{R} \$ / \mathrm{t}$.). Este ganho de eficiência econômica gera uma estimativa de redução de custo no produto final em torno de $2,96 \%$.

No modelo II, o número de viagens anuais necessárias para manter o abastecimento das indústrias se reduz significativamente (-43,9\%), o mesmo ocorrendo com a quilometragem total anual $(-46,4 \%)$ em que $60,1 \%$ dos quilômetros são percorridos em rotas que fazem conexão com fazendas de terceiros fornecendo quase a metade $(47,9 \%)$ de todo o volume de madeira transportado. Pode-se afirmar que em termos de matéria-prima madeira, quase a metade do volume (t.) movimentado no sistema resultou de trocas diretas observadas entre as indústrias. 


\subsection{Solução ótima do Modelo I versus solução ótima do Modelo II}

A comparação destes dois modelos toma sempre como referencial o modelo I e a diferença entre os resultados quantifica a contribuição da variável "tipo de caminhão" para o sistema. Tanto as composições das rotas quanto as quantidades transportadas de cada origem no modelo II ocorrem de maneira bastante semelhante ao observado no modelo I, porém com índice de trocas de fontes de abastecimento de 62,1\%, apresentando uma redução de $2,8 \%$ em relação ao modelo I. Ou seja, a adequação ao melhor tipo de caminhão absorve parte das ineficiências existentes devido à distribuição espacial inadequada das fontes de origem da madeira.

O número de rotas e as fazendas que abastecem mais de uma indústria também não se alteram, com exceção da fazenda $L W_{2}$ que sai da lista e da fazenda $E U_{6}$ que passa a fornecer madeira para três indústrias ao invés de duas.

O custo por viagem ( $\mathrm{R} \$$ viagem) sofre um aumento de $43,85 \%$ que é mais do que compensado por um acréscimo de $75,5 \%$ na quantidade de madeira transportada por quilômetro (t. $/ \mathrm{km}$ ) e por uma redução de $43,1 \%$ na quilometragem total percorrida, resultando em redução de $16,8 \%$ nos custos totais $(\mathrm{R} \$ 6.271 .478,00)$ e no custo da tonelada de madeira posta fábrica $(\mathrm{R} \$ / \mathrm{t}$.).

Com a possibilidade de optar pelo tipo de caminhão mais adequado economicamente ao transporte principal, o modelo II reduz em 21.637.400 quilômetros a distância total anualmente percorrida pelos veículos no abastecimento de madeira. Deste total, $60,1 \%$ ou 17.328.563 quilômetros são percorridos em rotas resultantes de trocas ou rotas de terceiros, praticamente não se alterando de um modelo para o outro a quantidade de madeira transportada nestas rotas.

Todas as indústrias participam do processo de trocas de fontes de abastecimento, apresentando índices que variam entre $40 \%$ e $80 \%$ para indústrias individualmente e em torno de 60\% para ambos os modelos na condição de sistema.

Como consequiência, observam-se elevados ganhos de eficiência operacional e econômica no transporte principal, o que permite questionamentos sobre a situação do transporte atualmente em prática pelas indústrias. Ambos os ganhos de eficiência levam 
a ganhos de competitividade que refletem em redução no custo do produto final o que consequentemente amplia a margem de lucro frente ao preço praticado no mercado.

O sistema apresenta ganhos de eficiência tanto técnica e econômica para ambos os modelos, com tendência crescente ao passar do modelo I para o modelo II, mostrando que a inclusão da variável "tipo de caminhão"" gera ganhos de um montante tal que é impossível desconsiderá-la no contexto do transporte principal de madeira para abastecimento industrial. A inserção desta variável e a adoção dos valores de fretes diferenciados por tipo de caminhão só são possíveis detendo-se o controle total da frota e deter tal controle significa ser proprietário da mesma ou integralizá-la verticalizando o transporte principal. Os ganhos de eficiência obtidos dão suporte à decisão administrativa contrária ao processo de terceirização do transporte principal de madeira.

Uma das razões para a adoção do processo de terceirização do transporte principal é o fato de que os custos dos serviços de coordenação através de contratos (custos de transações) sejam menores que os custos de operação com frota própria. Com a autoridade para definir o tipo de caminhão que compõe a frota, ocorre (segundo o modelo) uma sensível redução no custo total da operação de transporte principal, consequentemente redução no custo da tonelada de madeira posta fábrica, aumentando as possibilidades dos custos de operação serem menores do que os custos de transação, inviabilizando economicamente a terceirização.

Esta situação torna-se ainda mais favorável no sentido da não-terceirização quando se contabiliza a existência de outros ganhos adicionais possíveis de serem considerados, como as externalidades ${ }^{3}$ positivas da redução de $\mathrm{CO}_{2}$ e as reduções de custos administrativos devido às trocas de áreas de plantio, que é atualmente uma das maiores preocupações das indústrias.

\footnotetext{
${ }^{3}$ Segundo Randall (1987), externalidade em um conceito mais amplo ocorre quando o bem-estar de um indivíduo é afetado por uma atividade sob seu controle ou sob o controle de outrem.
} 


\subsection{Solução ótima dos modelos: bom para os lucros e para o meio ambiente}

Os excelentes resultados de ganhos comparativos entre o transporte realizado e as soluções ótimas dos modelos I e II abrem uma perspectiva no gerenciamento do setor florestal das indústrias. As comparações mostram a existência de um viés administrativo com base em decisões sobre o estágio de abastecimento que antecede a produção industrial (fábrica). Segundo o BNDES (1994), ANFPC (1995) e Bueno (1996) ${ }^{4}$, o processo de abastecimento, as altas taxas de juros e as altas despesas portuárias são fatores limitantes do desempenho e consequentemente da competitividade do setor.

A expectativa é de que os impactos positivos de tais possibilidades administrativas sejam suficientemente fortes para motivar novas pesquisas e iniciativas por parte das direções das empresas, buscando as vias de entendimento que viabilizem o rearranjo espacial das origens na oferta da matéria-prima madeira.

Nas análises do sistema, considera-se o interesse do conjunto como um único grande grupo empresarial fictício, cujo comportamento afeta o bem-estar social, gerando externalidades positivas e negativas. Os problemas ambientais caminham paralelos ao desenvolvimento econômico. Os transportes que são responsáveis pelo ir e vir, pelo abastecimento da sociedade de uma maneira geral, pela integração dos mercados e pela distribuição de bens não fogem à regra. Além de energia para realizar trabalho, os . motores de combustão interna emitem calor, ruído, partículas sólidas, líquidas e gases que são lançados na atmosfera, entre eles o $\mathrm{CO}_{2}$.

Já é consenso mundial a necessidade de se buscar redução nas emissões de gases de efeito estufa pelas indústrias dos países desenvolvidos e em desenvolvimento. Especificamente para $\mathrm{CO}_{2}$, a meta aceitável pelas Nações Unidas é atingir no fim da primeira década do próximo século (2012) um nível global de emissão de $\mathrm{CO}_{2}$ equivalente a $95 \%$ daqueles registrados em 1990, com custos estimados de centenas de bilhões de dólares por ano. Os primeiros projetos neste sentido definem um preço médio de US\$12/tonelada de CO, equivalente a US $\$ 4 /$ tonelada de $\mathrm{CO}_{2}$ fixado (Costa, 1998).

\footnotetext{
${ }^{4}$ Citados por Ribeiro (1998)
} 
Uma das maiores preocupações dos fabricantes de veículos automotores tem sido a busca de maior eficiência do combustível reduzindo o consumo. Um dos resultados deste estudo é exatamente a maior eficiência operacional da operação de transporte principal de madeira, reduzindo o consumo anual de óleo diesel para um mesmo volume de madeira transportado.

A operação de transporte principal, além de ser a mais importante do ponto de vista de custo de produção da madeira, é também a maior poluidora do meio ambiente, responsável por $57 \%$ do total das emissões de gases de efeito estufa que ocorrem nas operações florestais mecanizadas. ${ }^{5}$ Deve-se também levar em consideração a faixa de velocidade média de tráfego dos caminhões no transporte principal de madeira que, segundo resultados encontrados por Winther (1998), se situam exatamente naquela faixa de velocidade considerada a mais poluidora (entre 0 e $50 \mathrm{~km} / \mathrm{h}$ ).

As comparações dos resultados de Realizado versus Modelo I, Realizado versus Modelo II e Modelo I versus Modelo II promovem expectativas de reduções de quilometragem total percorrida anualmente pelo sistema de respectivamente 3.350.415, 24.987.815 e 21.637.400 quilômetros. Estas reduções de quilometragem no transporte principal eqüivalem a uma estimativa de reduções no consumo anual de combustível de respectivamente $1.675 .207,12.493 .907$ e 10.818 .700 litros de óleo diesel que não seriam queimados na combustão interna dos motores e que, portanto, deixariam de poluir ${ }^{6}$.

Esta não emissão de gases poluentes pode também ser estimada utilizando-se o padrão de emissão de 130 gramas de $\mathrm{CO}_{2}$ por quilômetro rodado, estabelecido por Joumard et al. (1995) para motores a diesel. Correlacionando a redução na quilometragem anual percorrida com o padrão estabelecido, tem-se, então, uma perspectiva de redução do $\mathrm{CO}_{2}$ emitido anualmente na atmosfera em consequiência da não queima de óleo diesel de respectivamente $6,2 \%$ ou 435,5 toneladas, $46,4 \%$ ou

\footnotetext{
S Trabalho desenvolvido na Finlândia por Karjalainen e Asikainen e publicado em 1996, ambos da Faculdade de Florestas da Universidade de Joensuu.

${ }^{6}$ Segundo as condições descritas pela Equipe técnica da Cia Suzano de Papel e Celulose (1996): topografia plano ondulada, motor de $300 \mathrm{hp}$, cavalo mecânico + SR 3E, 50 st/viagem, consumo médio de $2 \mathrm{~km} /$ litro de óleo diesel.
} 
$3.248,4$ toneladas e $40,2 \%$ ou $2.818,8$ toneladas, onde mais que os valores absolutos, deve-se ater aos valores percentuais.

As alternativas que as organizações mundiais apresentam para as indústrias poluidoras são de adotar medidas tecnológicas para reduzir as emissões ou garantir a sua remoção da atmosfera investindo em projetos de absorção no setor florestal via plantios de novos povoamentos ou via manejo de florestas. Portanto, esta redução na emissão de $\mathrm{CO}_{2}$ sem reduzir os níveis de atividade industrial pode ser considerada uma externalidade positiva do modelo de otimização do transporte principal de madeira, eqüivalendo ao custo do investimento que seria feito em projetos florestais para garantir sua absorção ou fixação.

\subsection{Champion Papel e Celulose Ltda.}

Nos modelos I e II a participação de rotas de terceiros no transporte principal é de respectivamente $57,1 \%$ e $66,6 \%$ no que diz respeito à fonte de abastecimento ou origem, recebendo madeira de fazendas pertencentes à Duratex e à Ripasa. Em termos de volume em toneladas de madeira posta fábrica, as trocas respondem por mais de $42 \%$ da demanda total anual da indústria. Considerando-se quilometragem anual percorrida, as rotas que levam às fazendas de terceiros respondem por $84,2 \%$ e $76 \%$ do total nos modelos I e II, respectivamente.

Os custos totais anuais apresentam redução para os modelos de otimização, com quedas bastante significativas da ordem de $5 \%(\mathrm{R} \$ 383.018,00)$ e $24,8 \%$ ( $\mathrm{R} \$$ 1.895.567,00), tendência que se repete de maneira idêntica em percentual para os custos da tonelada de madeira posta fábrica $(\mathrm{R} \$ / \mathrm{t}$.).

Considerando que seja necessário uma frota de no mínimo 67 caminhões do tipo $\mathrm{k}_{3}$ para atender à demanda anual de toras curtas de eucalipto, a redução obtida no 
custo total anual com o modelo I seria suficiente para renovar 5,2\% da frota a cada ano, sendo que neste ritmo após 19 anos toda a frota seria renovada. ${ }^{7}$ Com as reduções de custos observadas no modelo II, seria possível renovar 25,6\% da frota a cada ano e no espaço de três anos e 9 meses toda a frota seria renovada.

O modelo I apresenta um acréscimo de 89.397 quilômetros na distância total percorrida no abastecimento, aumentando a quilometragem por tonelada de madeira posta fábrica, o que significa perda de eficiência operacional em função de ganhos de eficiência econômica. Este fato não se constitui em problema, uma vez que as funções objetivos são de minimização de custos e não de distâncias. Além disto, os modelos foram elaborados considerando-se uma visão agregada do sistema e não a situação particular de uma indústria isoladamente.

O modelo II eleva sensivelmente os ganhos de eficiência operacional para a indústria, apresentando uma redução de 44,6\% na quilometragem total percorrida e redução de 42,8\% no número de viagens necessárias para cumprir com o abastecimento anual. A distância média percorrida por viagem $(\mathrm{km} / \mathrm{viagem})$ foi reduzida em apenas $4,1 \%$, demonstrando de maneira evidente a significativa contribuição da maior capacidade de carga do tipo de caminhão (k4) selecionado pelo modelo.

A distribuição espacial dos municípios onde se localizam as fazendas responsáveis pelo abastecimento realizado no ano de 1996 mostra uma dispersão homogênea nas bordas de um círculo imaginário na região leste do estado, com centro na cidade de Piracicaba. A otimização do sistema, com os modelos I e П, leva a uma redistribuição das fazendas em municípios formando um triangulo na região nordeste do estado, com vértice em Mogi Guaçu, Altinópolis e Lençóis Paulista.

\footnotetext{
${ }^{7}$ Estimativas dos valores de mercado referentes ao $2^{\circ}$ semestre de 1996, levantadas junto às indústrias participantes e no Florestar Estatístico (1996). Valores referentes a caminhões novos, equipados para transporte de madeira, licenciados e com seguro pago.

$\mathrm{K}_{1}=\mathrm{R} \$ 51.000,00 \quad \mathrm{cck}=13,8 \mathrm{t}$.

$\mathrm{K}_{2}=\mathrm{R} \$ 100.000,00$ cck $=26,6 \mathrm{t}$.

$\mathrm{K}_{3}=\mathrm{R} \$ 120.000,00$ cck $=28,8 \mathrm{t}$.

$\mathrm{K}_{4}=\mathrm{R} \$ 140.000,00$ cck $=49,9 \mathrm{t}$.

$\mathrm{Na}$ análise de ganhos em termos de renovação de frota, toma-se como referência para todas as indústrias, o tipo de caminhão que consta na tabela 19, para um período de 300 dias úteis no ano e média de 2 viagens por dia por rota.
} 


\subsection{Duratex S/A}

De todas as seis indústrias, a Duratex seria a mais favorecida pela adoção do processo de trocas uma vez que ela é a que apresenta os maiores percentuais de participação de fazendas de terceiros no abastecimento (80\%), recebendo madeira de fazendas da Eucatex, Lwarcel, Ripasa e Suzano. Estas trocas respondem por quase $71 \%$ do volume em toneladas de madeira anualmente transportadas para consumo industrial e pela quase totalidade dos quilômetros percorridos no abastecimento, chegando a 94,5\% de participação.

A redução no custo total anual e no custo da tonelada de madeira posta fábrica é da ordem de $28,5 \%$ para ambos os modelos I e II ( $\mathrm{R} \$ 1.138 .970,00)$, quando comparados com o Realizado. Considerando que para atender à demanda anual de $547.363,8$ toneladas de madeira seja necessária uma frota de 18 caminhões do tipo k4, realizando em média duas viagens por dia, o ganho obtido em eficiência econômica garantiria a aquisição de oito caminhões anualmente, o que significa renovar toda a frota em um intervalo de dois anos e 3 meses.

Há um aumento exorbitante na quantidade total dos quilômetros anualmente percorridos (111\%), bem como na quilometragem por tonelada de madeira posta fábrica para os modelos I e II. O número de viagens realizadas por ano se mantém constante, porém as viagens na média tornam-se duas vezes mais longas, demonstrando uma grande queda de eficiência operacional.

Apesar do elevado percentual de trocas de fontes de abastecimento e do forte intercâmbio apresentado com as demais indústrias, a distribuição espacial dos municípios resultante das otimizações não difere muito do realizado. 


\subsection{Eucatex S/A}

A reestruturação da distribuição espacial das origens da madeira apresenta índices de troca de $50 \%$ e $40 \%$ para os modelos de transporte I e II, respectivamente, ou seja, metade das fazendas que abastecem a indústria não pertence ao mesmo grupo empresarial. As indústrias que apresentam trocas com a Eucatex são a Champion, a Duratex e a Lwarcel, cujas fazendas nos modelos I e II respondem por respectivamente $36,3 \%$ e $42,5 \%$ do volume de madeira transportada (t. /ano) e por $64,1 \%$ e $50,7 \%$ da quilometragem anualmente percorrida para o abastecimento.

O modelo I apresenta uma perda de eficiência operacional com acréscimo de $7,8 \%$ na quilometragem anual percorrida, sem alteração do número de viagens necessárias. O modelo II apresenta ganho de eficiência operacional com uma redução de $39,2 \%$ na quilometragem total e de $45,3 \%$ no número de viagens, sem comprometer o abastecimento da indústria no período considerado.

A Eucatex no modelo I é o único caso de elevação dos custos totais anuais de transporte observado em todo o trabalho, com uma variação de positiva de $4,1 \% \mathrm{em}$ relação ao custo realizado, significando perda de eficiência econômica e elevação dos custos da tonelada de madeira posta fábrica ( $\mathrm{R} \$ \mathrm{t}$.), apesar de redução nos custos por quilômetro percorrido $(\mathrm{R} \$ / \mathrm{km})$.

Observando-se a performance em termos de custos anuais tanto para o modelo I $(+4,1 \%)$ como para o modelo II $(-16,4 \%)$, a Eucatex comparativamente é a indústria que apresenta os menores ganhos de eficiência econômica dentro do sistema.

O abastecimento da indústria no ano de 1996 define um eixo no sentido nortesul, ligando os municípios de Salto, Itu, Salto de Pirapora e Pilar do Sul em torno do qual gravitam dois outros municípios dispersos na região oeste do estado. A otimização do sistema reorienta a distribuição destas fontes de abastecimento segundo um eixo no sentido leste-oeste unindo os municípios de Lençóis Paulista, Itatinga, Botucatu, Salto e Itu. 


\subsection{Lwarcel Celulose e Papel Ltda.}

A reorientação das rotas de transporte cujo percentual reflete a tendência da empresa para o intercâmbio de matéria-prima madeira apresenta uma uniformidade de trocas de 50\% com fazendas da Ripasa S/A, parceiro único que responde ainda por $46 \%$ do volume anual (t.) de madeira demandada pela indústria. Cerca de $23,2 \%$ e $36,1 \%$ da quilometragem percorrida anualmente pelos caminhões no processo de abastecimento nos modelos I e II se dá em rotas que ligam a indústria a fazendas de propriedade da Ripasa S/A.

Os modelos apresentam ganhos de eficiência operacional de $40,7 \%$ e $80,3 \%$ no transporte principal, medidos pela redução na quilometragem total e na demanda de quilômetros por tonelada de madeira posta fábrica. O modelo I apresenta o mesmo número de viagens que o Realizado, porém dentro de um percurso médio ( $\mathrm{km} / \mathrm{viagem}$ ) $40 \%$ menor, implicando em menos tempo gasto com o transporte no abastecimento. $\mathrm{O}$ modelo II, além de reduzir drasticamente o número de viagens anuais $(-61,2 \%)$, diminui também o percurso médio de maneira significativa $(-49,2 \%)$, resultando em queda de $80 \%$ na demanda de quilômetros por tonelada de madeira posta fábrica $(\mathrm{km} / \mathrm{t}$.).

A demanda de $254.110,1$ toneladas de toras curtas de eucalipto por ano significa uma demanda diária de 847 toneladas (254.110,1 t. / 300 dias úteis), que considerando duas viagens por dia requer uma frota de no mínimo 31 caminhões $\left(k_{1}\right)$ para garantir o abastecimento da indústria. A redução de $\mathrm{R} \$ 469.046,00$ (40,7\%), obtida com o modelo I nos custos totais anuais, significa condições para aquisição de nove caminhões equipados $\left(\mathrm{k}_{1}\right)$ por ano, ou seja, em três anos e meio a frota seria toda renovada. Para o modelo II, com uma redução de $\mathrm{R} \$ 603.639,00$ (52,4\%), a renovação total da frota dar-se-ia antes dos dois anos e meio, adquirindo 12 caminhões novos e equipados por ano.

O aumento de $142 \%$ nos custos por quilômetro percorrido $(\mathrm{R} \$ / \mathrm{km})$ devido à alteração do tipo de caminhão adotado é mais do que compensado pela forte redução de $80 \%$ na quilometragem necessária por tonelada de madeira posta fábrica $(\mathrm{km} / \mathrm{t}$.), gerando uma redução final de $52,4 \%$ nos custos da tonelada transportada (R $\$ / t)$. 
A Lwarcel é entre todas as indústrias estudadas a que apresenta os mais elevados índices percentuais de redução de custos e de quilometragem, consequentemente apresentando os maiores ganhos de eficiência operacional e econômica com a adoção dos modelos de otimização. Porém, em termos de integração ou intercâmbio com as demais indústrias, ela apresenta os menores índices percentuais de trocas $(50 \%)$ que são processadas interagindo com apenas uma delas.

\subsection{Ripasa S/A}

A reorientação das rotas na solução ótima dos modelos de transporte I e II apresenta composições finais onde $71,4 \%$ e $66,6 \%$ das fazendas são de propriedade de empresas não pertencentes ao mesmo grupo empresarial da Ripasa. As indústrias com as quais se processam as trocas no abastecimento são a Champion Papel e Celulose Ltda., a Eucatex S/A e a Cia Suzano de Papel e Celulose, que respondem conjuntamente pelo maior índice percentual de trocas observado em termos de toneladas de madeira transportada $(71,9 \%)$ e pelo terceiro maior índice $(70 \%)$ em termos de quilometragem percorrida unindo fazendas de terceiros com a indústria.

Os modelos I e II promovem reduções nos custos totais da ordem de $\mathrm{R} \$$ 1.647.267,00 (-18,7\%) e $\mathrm{R} \$ 3.152 .140,00$ (-35,8\%) respectivamente, com reflexo de mesma magnitude nos custos da tonelada de madeira posta fábrica $(\mathrm{R} \$ / \mathrm{t}$.). Estes ganhos significam para a indústria a possibilidade de aquisição anual de 16,5 e 31,5 novas unidades de caminhões $\left(\mathrm{k}_{2}\right)$ equipados para o transporte principal de madeira. Considerando que o tamanho mínimo de frota necessário para atender à demanda anual de madeira seja de 51 caminhões do tipo $\mathrm{k}_{2}$ ( $\mathrm{cck}=26,6 \mathrm{t}$.), as reduções de custos totais significam condições de renovar toda a frota em três anos no caso do modelo I e em um ano e meio no caso do modelo II.

Ambos os modelos, I e II, apresentam ganhos de eficiência operacional com redução $16 \%$ e $53 \%$ na quilometragem anual percorrida e redução de $16 \%$ e $13,7 \%$ na distância média percorrida por viagem ( $\mathrm{km} /$ viagem). 
A introdução da variável "tipo de caminhão" no modelo I, gerando o modelo II, propicia uma redução de 14.305 viagens $(-46,7 \%)$ na demanda necessária para proceder ao abastecimento anual, com um incremento de 11 quilômetros $(+2,8 \%)$ na distância por viagem $(\mathrm{km} /$ viagem). Considerando que o tempo de percurso por viagem se mantenha o mesmo (101 viagens /dia), esta redução equivale a menos 141 dias úteis ou cinco meses e meio a menos (141 dias úteis/25 dias úteis) no tempo necessário para atender à demanda anual da indústria.

Os municípios responsáveis pelo abastecimento no ano de 1996 se distribuem claramente em um eixo no sentido norte-leste, unindo os municípios de Campinas, Americana, Itirapina, Ibaté e Boa Esperança do Sul. A otimização do sistema define um novo eixo de abastecimento no sentido sul-leste, unindo Itatinga, Avaré, Agudos, Brotas, Ibaté e Santa Rita do Passa Quatro.

\subsection{Cia Suzano de Papel e Celulose}

A recombinação de rotas promovida pelas soluções ótimas dos modelos I e II indica uma participação de fazendas de terceiros com responsabilidades no abastecimento industrial de respectivamente $63,6 \%$ e $66,6 \%$ do total de fazendas. Quando se considera a participação de terceiros em termos de toneladas de madeira posta fábrica, os percentuais se reduzem para $23 \%$ e $29 \%$ do volume total anual de madeira movimentado. Em termos de quilômetros percorridos em rotas unindo a indústria a fazendas de terceiros, os percentuais giram em tomo de $33 \%$ e $42 \%$, os menores valores observados entre todas as indústrias.

Esta indústria é a que apresenta a maior diversidade no intercâmbio, interagindo com todas as outras cinco no processo de otimização promovido pelos modelos I e II.

Os modelos I e II apresentam redução nos custos totais em relação ao transporte praticado (Realizado). O primeiro com índice de $10,6 \%(\mathrm{R} \$ 1.267 .971,00)$ e o segundo com $30,4 \%(\mathrm{R} \$ 3.623 .544,00)$, percentuais que se repetem para o custo da tonelada de madeira posta fábrica $(\mathrm{R} \$ / \mathrm{t}$.). 
Considerando-se a demanda anual de madeira em 1.195.904 toneladas e um ano de 300 dias úteis, as demandas diárias de 3.986,3 toneladas seriam transportadas por uma frota composta de no mínimo 75 caminhões do tipo $\mathrm{k}_{2}$ trabalhando em uma jornada média de duas viagens por dia. Ao preço unitário de $\mathrm{R} \$ 100.000,00$ o veículo novo licenciado, segurado e equipado para transporte de madeira, as reduções anuais proporcionadas pelos modelos I e II são suficientes para adquirir 12,6 e 36,2 caminhões respectivamente, ou seja, a frota seria toda renovada em um prazo de seis anos no modelo I e de dois anos no modelo II.

O efeito das otimizações do transporte principal nos modelos I e II promove uma redução na quilometragem total percorrida de 2.664.723 e 10.956 .074 quilômetros respectivamente, gerando reduções na quilometragem por tonelada posta fábrica $(\mathrm{km} / \mathrm{t}$.) de $13 \%$ e $54 \%$, e na distância média de transporte $(\mathrm{km} /$ viagem), de $13 \%$ para ambos os modelos.

Inicialmente, a distribuição espacial dos municípios sedes das fazendas fornecedoras de madeira (Realizado) concentra-se claramente na região sul-leste. A otimização do sistema mostra uma tendência para concentração dos municípios que abastecem a indústria, na região leste do estado.

\subsection{Perspectivas de entendimento entre indústrias no processo de trocas}

A análise da situação individual de cada uma das indústrias no que diz respeito à sua eficiência econômica enquanto componente do sistema é o que sinaliza as possibilidades da existência de entendimento entre elas no que diz respeito à troca de fontes de abastecimento. Em outras palavras, o interesse individual das indústrias de participarem do processo de trocas depende fundamentalmente de seus ganhos individuais de eficiência econômica enquanto partes do sistema.

O processo de intercâmbio no modelo I, apesar de apresentar ganhos significativos para o sistema como um todo, apresenta perda de eficiência operacional e econômica para uma das indústrias participantes (EU) que, consequentemente, se vê desestimulada a participar do processo. A introdução da variável "tipo de caminhão", 
porém (Modelo II), contorna a situação fazendo com que todas as indústrias indistintamente apresentem ganhos de eficiência econômica com as trocas (Tabela 25).

Portanto, a hipótese de ganhos de eficiência para todas as indústrias devido apenas à redistribuição das fontes de abastecimento de madeira não se confirma com a simples quebra do vínculo de propriedade entre povoamento e indústria. Torna-se necessário acrescentar ao modelo a opção "tipo de transporte", diferenciando o tipo de veículo utilizado no transporte principal.

Tabela 25. Listagem e ordem das indústrias segundo os impactos nos custos totais de transporte.

\begin{tabular}{c|cccccc}
\hline Indústria & Modelo I & Ordem & Modelo III & Ordem & Modelo II & Ordem \\
\hline LW & $-40,7 \%$ & $1^{\circ}$ & $-40,7 \%$ & $2^{\circ}$ & $-52,4 \%$ & $1^{\circ}$ \\
DU & $-28,5 \%$ & $2^{\circ}$ & $-43,0 \%$ & $1^{\circ}$ & $-28,5 \%$ & $4^{\circ}$ \\
RI & $-18,7 \%$ & $3^{\circ}$ & $-24,4 \%$ & $4^{\circ}$ & $-35,9 \%$ & $2^{\circ}$ \\
SU & $-10,6 \%$ & $4^{\circ}$ & $-12,8 \%$ & $6^{\circ}$ & $-30,4 \%$ & $3^{\circ}$ \\
CH & $-5,0 \%$ & $5^{\circ}$ & $-17,8 \%$ & $5^{\circ}$ & $-24,8 \%$ & $5^{\circ}$ \\
EU & $+4,1 \%$ & $6^{\circ}$ & $-33,5 \%$ & $3^{\circ}$ & $-16,4 \%$ & $6^{\circ}$ \\
\hline
\end{tabular}

Fonte: Resultados do estudo

Os esforços de entendimento são favorecidos, ao se analisar as perspectivas demonstradas pelos modelos individuais de otimização (modelo III), onde esta mesma indústria antes desestimulada (EU) apresenta a terceira maior expectativa de ganho de eficiência econômica (Tabela 25).

A existência de horizonte para entendimentos se confirma na primeira tentativa ao introduzir a variável "tipo de caminhão" como uma opção a mais no modelo I gerando o modelo II. A solução ótima passa então a apresentar ganhos de eficiência econômica acima dos $16 \%$ para todas as indústrias e ganhos de eficiência operacional para quase todas (Modelo II nas tabelas 25 e 26). Esta situação viabiliza teoricamente a possibilidade de entendimento nas trocas e confirma a tendência da não terceirização do transporte principal como a melhor opção também em nível de indústria. 
A introdução da variável tipo de caminhão gera ganhos de eficiência operacional (Tabela 26) de magnitude tal que contorna em parte a má distribuição espacial das fontes de abastecimento existentes na condição de transporte realizado pelas indústrias no ano de 1996 (Realizado).

Tabela 26. Listagem e ordem das indústrias segundo os impactos na quilometragem percorrida.

\begin{tabular}{c|cccccc}
\hline Indústria & Modelo I & Ordem & Modelo III & Ordem & Modelo II & Ordem \\
\hline LW & $-40,7 \%$ & $1^{\circ}$ & $-40,7 \%$ & $1^{\circ}$ & $-80,3 \%$ & $1^{\circ}$ \\
DU & $-16,1 \%$ & $2^{\circ}$ & $-27,3 \%$ & $4^{\circ}$ & $-53,9 \%$ & $2^{\circ}$ \\
RI & $-13,0 \%$ & $3^{\circ}$ & $-15,9 \%$ & $6^{\circ}$ & $-53,8 \%$ & $3^{\circ}$ \\
SU & $0,82 \%$ & $4^{\circ}$ & $-20,5 \%$ & $5^{\circ}$ & $-44,6 \%$ & $4^{\circ}$ \\
CH & $7,8 \%$ & $5^{\circ}$ & $-34,2 \%$ & $2^{\circ}$ & $-39,2 \%$ & $5^{\circ}$ \\
EU & $111,4 \%$ & $6^{\circ}$ & $-33,2 \%$ & $3^{\circ}$ & $111,4 \%$ & $6^{\circ}$ \\
\hline
\end{tabular}

Fonte: Resultados do estudo.

A má distribuição espacial em Realizado fica evidente ao constatar que:

a) vinte e cinco por cento $(25 \%)$ das trinta e duas fontes de abastecimento $\left(\mathrm{CH}_{4}, \mathrm{CH}_{6}\right.$, $\mathrm{DU}_{2}, \mathrm{DU}_{3}, \mathrm{EU}_{5}, \mathrm{RI}_{3}, \mathrm{RI}_{6}, \mathrm{RI}_{7}$ ) não participam de nenhuma das opções de rotas em nenhuma das seis soluções ótimas encontradas no modelo III (Tabela 21); e

b) os elevados percentuais de participação (23\%, 33\%, entre 36\% e 94,2\%) referentes à quilometragem anual percorrida em rotas de fazendas de terceiros, quando comparados à quilometragem total anual percorrida pelo transporte principal no abastecimento das indústrias (Tabela 24).

Os efeitos da magnitude dos ganhos de eficiência operacional podem ser percebidos na coluna de eficiência operacional da Tabela 27, onde é expurgada a contribuição da quebra do vínculo de propriedade, restando o efeito devido à introdução da variável tipo de caminhão. Os resultados mostram que no caso da inviabilidade de uma determinada indústria de participar do processo de troca de madeira, uma possível 
solução isolada seria a decisão de verticalizar a operação de transporte principal para contornar em parte os problemas de ineficiências.

Tabela 27. Ganhos de eficiência operacional e econômica devido à adoção da variável tipo de transporte.

\begin{tabular}{c|cc}
\hline Indústrias & E. Econômica & E. Operacional \\
\hline CH & $19,8 \%$ & $45,4 \%$ \\
DU & $0 \%$ & $0 \%$ \\
EU & $20,5 \%$ & $47,0 \%$ \\
LW & $11,7 \%$ & $39,6 \%$ \\
RI & $17,2 \%$ & $37,8 \%$ \\
SU & $19,8 \%$ & $40,8 \%$ \\
\hline Sistema & $16,8 \%$ & $40,2 \%$ \\
\hline
\end{tabular}

Fonte: Estimativas deste estudo

Pela Tabela 22, comparando para cada indústria os resultados do modelo I com os modelos individualizados (Modelo III) na coluna "\% terceiros", percebe-se que apenas uma delas (LW) está no percentual de trocas de fontes de abastecimento considerado ideal pelo modelo III. A situação das demais mostra que elas, inseridas no sistema, estão promovendo trocas com terceiros além ou aquém do ponto considerado ideal, havendo espaço para futuros entendimentos em termos de opções de fontes de abastecimento. No que diz respeito ao percentual de trocas em termos de toneladas de madeira (Tabela 24), observando a mesma coluna "\% terceiros", nota-se que duas indústrias (DU e LW) estão no limite considerado ideal. Uma outra $(\mathrm{CH})$ está promovendo trocas (inserida no sistema) acima do limite ideal e as outras três (EU, RI e SU) promovem trocas aquém dos seus limites ideais, demonstrando, nesta diversidade de situações, a existência de espaço e condições para futuros entendimentos em se tratando de toneladas de madeira.

Os índices de eficiência operacional e econômica - devido aos efeitos da adoção da variável tipo de caminhão (Tabela 27) e devido aos efeitos da quebra dos vínculos de 
propriedade da madeira (Tabela 28)- dizem respeito às contribuições possíveis de serem feitas ao transporte principal realizado no ano de 1996.

Olhando apenas o aspecto da eficiência operacional do sistema, o índice de ganho para a variável "tipo de caminhão" (40,2\%) se mostra bastante superior ao da quebra de vínculo de propriedade $(6,22 \%)$, demonstrando que o sistema como um todo se encontra muito aquém das condições técnicas consideradas ideais para o transporte principal de madeira.

Tabela 28. Ganhos de eficiência operacional e econômica devido à quebra do vínculo de propriedade da madeira.

\begin{tabular}{c|cc}
\hline Indústrias & E. Econômica & E. Operacional \\
\hline CH & $5,0 \%$ & $-0,82 \%$ \\
DU & $28,5 \%$ & $-111,4 \%$ \\
EU & $-4,1 \%$ & $-7,8 \%$ \\
LW & $40,7 \%$ & $40,7 \%$ \\
RI & $18,7 \%$ & $16,1 \%$ \\
SU & $10,6 \%$ & $13,0 \%$ \\
\hline Sistema & $12,8 \%$ & $6,22 \%$ \\
\hline
\end{tabular}

Fonte: Estimativas deste estudo

Individualmente, todas as indústrias apresentam índices de ganho de eficiência operacional devido à adoção da variável "tipo de caminhão" variando entre 37,8\% e $47 \%$, com exceção de uma delas que apresenta índice de $0 \%$ de ganho (DU). Índice de ganho de eficiência operacional da ordem de $0 \%$ significa que esta indústria não se encontra defasada tecnicamente no que diz respeito ao transporte principal de madeira, e coincidentemente ou não, ela é também a única entre as seis indústrias que não terceirizou este serviço.

Apesar da eficiência operacional não ser o objeto principal dos modelos, na prática, os reflexos em termos de quilometragem adicional ou quilometragem reduzida tornam-se importantes a partir do momento que existe um planejamento estratégico de 
abastecimento de madeira a ser obedecido dentro de um cronograma e dentro de um intervalo de tempo rigorosamente pré-definidos. As adaptações das indústrias a estas alterações aparentemente se tornam mais complexas em se tratando de quilometragem adicional (redução de eficiência operacional), que envolve modificações nas jornadas de trabalho dos turnos de recebimento de madeira, no número de equipes para atendimento, no número de caminhões que compõem a frota, no número de viagens necessárias por dia, podendo gerar custos administrativos adicionais para a indústria e que não foram abordados neste trabalho. Isto ocorre devido ao fato que o aumento de quilometragem não pode simplesmente se transformar em número de viagens adicionais sem levar em consideração o espaço de tempo pré-determinado para que tais viagens ocorram. Este adicional de viagens significa adicional de tempo para suas realizações, exigindo ajustes logísticos que não podem ser feitos no curto prazo, correndo o risco de extrapolar o intervalo pré-determinado de um ano para atender à demanda projetada pelas indústrias. 


\section{CONCLUSÕES}

Informações relativas ao transporte de madeira efetivamente realizado pelas seis indústrias analisadas neste trabalho foram comparadas com os resultados apresentados por três diferentes modelos matemáticos de otimização, considerando os aspectos agregados em sistema e individualizados por indústria.

Os três modelos distinguem-se quanto à forma como detalham os meios de transporte e à forma como permitem a troca de matéria-prima entre indústrias. Assim, o modelo matemático básico (Modelo I) estabelece um único meio de transporte por rota, sem especificá-lo, apresentando uma estratégia final que minimiza o custo total.

Um segundo modelo (Modelo II) considera diferentes meios alternativos de transporte por rota e apresenta uma estratégia final que minimiza o custo total, especificando inclusive o tipo de caminhão de mínimo custo por rota.

O terceiro modelo (Modelo III), tal qual o modelo I, estabelece um único meio de transporte por rota sem especificá-lo e considera cada indústria individualmente, oferecendo-lhe, entretanto, como opção o total de madeira disponível em todas as 32 fontes de abastecimento. Esta abordagem, que só faz sentido na análise individual por indústria, permite avaliar uma situação limite, na qual as demandas das demais indústrias são ignoradas e onde apenas a madeira de menor custo de transporte é entregue na fábrica. Assume-se que não é possível gerar custo total de transporte inferior a este e que, portanto, estes resultados oferecem referências de máxima eficiência ou de condição ideal dadas as circunstâncias.

Não há dúvidas de que as indústrias enfrentam um problema camuflado, cuja magnitude tende a crescer e a se agravar com o crescimento do mercado e da produção. Para ganhos de eficiência e eficácia no processo de transporte de madeira serão 
necessárias decisões e vontade políticas imediatas que permitam a comunicação e a discussão conjunta da questão. Esta via pode representar uma nova opção, dar suporte e garantir o nível de competitividade do setor.

Os resultados demonstram a necessidade de se criar condições para o entendimento entre as empresas do setor florestal, principalmente no que diz respeito a discussão dos problemas de abastecimento das indústrias.

Como todos os modelos, os de programação matemática são meras abstrações da realidade, uma vez que não conseguem captar todos os seus aspectos, concentrando seu foco nos objetivos quantificáveis como a minimização de custos nos problemas de transporte. No caso específico deste estudo, outros aspectos da realidade têm forte influência no processo de tomada de decisão como os fatores ambientais, sociais e políticos que condicionam as relações entre as indústrias e que devem ser considerados.

Pelos resultados alcançados verificou-se que:

1) A metodologia utilizada é compatível com a proposta de trabalho, o que se demonstra pela qualidade e adequação dos resultados obtidos nas soluções ótimas, pela flexibilidade encontrada na abordagem do problema e no atendimento aos objetivos.

2) Fica confirmada a existência de ineficiências na distribuição espacial das fazendas produtoras de toras curtas de eucalipto em relação às suas respectivas indústrias consumidoras no estado de São Paulo. Os elevados resultados de índices de trocas observados nos modelos de otimização e a exclusão de $25 \%$ das fontes de abastecimento das soluções ótimas dos modelos individualizados demonstram que, no planejamento e na construção destas fábricas (notadamente na região leste do estado), a preocupação vigente era com o escoamento da produção (transporte do produto final) em detrimento do abastecimento de matéria-prima madeira (transporte principal). 
3) A hipótese de ganhos de competitividade através da redistribuição das fontes de abastecimento é verdadeira para a condição de sistema. Individualmente, na condição de indústria, não se confirma pelo fato de uma delas (Eucatex) apresentar aumento de custos. Neste caso, esta indústria não se sentiria estimulada a participar do processo de intercâmbio de matéria-prima por apresentar perda de eficiência econômica.

4) A hipótese acima torna-se verdadeira tanto para a condição de sistema quanto para a condição de indústrias individualmente ao se considerar no Modelo I, além da quebra de vínculo de propriedade da madeira, também a introdução da variável tipo de caminhão.

5) A melhor alternativa encontrada de redistribuição das fontes de abastecimento foi caracterizada pelo Modelo II que combina a quebra de vínculo de propriedade da madeira com a inclusão da variável tipo de caminhão utilizado no transporte principal. Esta alternativa gera os maiores índices de ganhos de eficiência econômica tanto para o sistema como para todas as indústrias individualmente, garantindo a veracidade da hipótese e fornecendo o estímulo necessário para que todas elas participem do processo de trocas.

6) O impacto da variável "tipo de caminhão" no índice de trocas tanto para indústrias individualmente como para o sistema é praticamente nulo, contrariamente ao seu forte impacto na melhoria da eficiência operacional do transporte principal.

7) Todas as seis indústrias participam em maior ou menor intensidade do processo de trocas, cujos ganhos em eficiência econômica transferem para o produto final reduções de custo que variam entre $1,28 \%$ e $2,96 \%$ em termos de sistema e entre $1,64 \%$ e $5,24 \%$ em termos de indústrias individualmente. 
8) Os ganhos individuais de eficiência operacional e econômica, juntamente com os índices individuais de trocas de fontes de abastecimento (entre $40 \%$ e $80 \%$ ) e de trocas de madeira (entre 23,3\% e 71,98\%) entre indústrias, confirmam a decisão de reestruturar as combinações "origem-destino" da matéria-prima madeira como uma opção administrativa a mais e com reais possibilidades de melhoria do nível de competitividade das indústrias, sem interferir no abastecimento do setor de transformação.

9) A efetiva contribuição da variável "tipo de caminhão", em termos de ganhos de eficiência operacional e econômica, tanto para as indústrias individualmente quanto para o sistema, coloca em questionamento o processo de terceirização do transporte principal da matéria-prima madeira como opção de menor custo no abastecimento industrial. A não terceirização do serviço (verticalização) permite à indústria definir melhor operacionalmente o tipo de caminhão mais adequado para realizar o transporte principal. Este questionamento deve ser tratado em novas pesquisas, preferencialmente em estudo de caso onde tais relações possam ser melhor detalhadas.

10) O transporte principal de madeira praticado pelas indústrias (Realizado) apresenta-se defasado tecnicamente tanto para a condição de sistema como individualmente. Para cinco das seis indústrias consideradas, os valores observados se mostram muito aquém das condições consideradas ideais, gerando ineficiências operacionais $(37,8 \%$ a $47 \%)$ por inadequação do tipo de caminhão utilizado. O fato sugere que o transporte principal nas indústrias está melhor administrado em termos de eficiência econômica do que operacional, demonstrando uma maior concentração de esforços no aspecto custo em detrimento do aspecto operacional do transporte.

11) Com a quebra do vínculo de propriedade da madeira, todas as indústrias apresentam individualmente um grande potencial (Modelo III) em termos de margem de ganho de eficiência operacional $(15,9 \%$ a 40,7\%) e econômica (12,8\% a 43\%), reunindo condições de entendimento e estímulo para participarem das discussões de uma possível política de trocas. 


\section{REFERÊNCIAS BIBLIOGRÁFICAS}

ABEL, D.B. Linear programming and its application to the locational planning of wood-processing industries. New-Zealand Journal of Forestry Science, v.2, n.3, p.259-269, 1973.

ASSOCIAÇÃO BRASILEIRA DOS PRODUTORES DE MADEIRA. Brasil mostra seu potencial. Revista da Madeira, n.30, 1997.

ASSOCIAÇÃO BRASILEIRA DOS PRODUTORES DE MADEIRA. Oferta de madeira tende a ser menor. Revista da Madeira, n.20, 1995.

ASSOCIAÇÃO NACIONAL DOS FABRICANTES DE PAPEL E CELULOSE. Relatório Estatístico Florestal GT 7, Reflorestamento e Correlatos. São Paulo: ANFPC, 1996.

BARR, B.M. The soviet wood-processing industry. London: Oxford University Press, 1970.

BERG, M.; LARSSON, H. A planning system for timber transport optimization at Sodra. Arbetsrapport, n.190, 46p. 1994.

BERGER, R. Minimização do custo de transporte de madeira de eucalipto no estado de São Paulo. Piracicaba, 1975. 122p. Dissertação (Mestrado) - Escola Superior de Agricultura "Luiz de Queiroz", Universidade de São Paulo. 
BERTOLANI, F. Mercado para chapas e aglomerados. In: SIMPÓSIO FLORESTAL DO RIO GRANDE DO SUL, Porto Alegre, 1993. Anais. Porto Alegre: UFSM/CEPEF, 1993. p.121-126.

BIDZISNKA, G.; KOSICKA, K.; WALKOWIAK, M. Optimization of transport in forestry and wood processing industries. Prace Instituto de Tecnologia Drewna, v.31, p.3-15, 1985.

BONITA, L.M. Location of forest industries in the Philippines. In: SEMINAR ON STORAGE, TRANSPORT AND SHIPPING OF WOOD, Singapura, 1977. Anais. Rome: FAO, 1977. p.45-62.

BRACCO, A. Corrida contra o relógio. Celulose \& Papel, n.55, p.11-14, 1996.

BRACK, C.L.; MARSHALL, P.L. A test of knowledge-based forest operations scheduling procedures. Canadian Journal of Forest Research, v.26, n.7, p.1193-1202, 1996.

BURGER, D.H.; JAMNICK, M.S. Using linear programming to make wood procurement and distribution decisions. Forestry Chronicle, v.71, n.1, p.89-96, Jan./Feb. 1995.

CAIXETA FILHO, J.V. A utilização de modelagem pelas empresas florestais. Silvicultura, n.52, p.18-20, nov./dez. 1993.

CARLSSON, D.; ARVIDSSON, P. A. Optimized route planning - good for both: profits and the environment. Resultat-SkogForsk, n.23, 4p., 1998. 
CARNIERI, C. O uso de algorítimo de otimização de redes na exploração florestal. In: SEMINÁRIO DE ATUALIZAÇÃO SOBRE SISTEMAS DE EXPLORAÇÃO E TRANSPORTE FLORESTAL, Curitiba, 1989. Anais. Curitiba: FUPEF/UFPr, 1989. p.233-235.

CARTER, D.R.; ARVANITIS, L.G.; BRACKETT, D.; BOYCHEVA, V.; SAGER, S. A decision support system for timber. Journal of Forestry, v.97, n.6, p.12-18, June. 1999.

CHINNECK, J.W.; MOLL, R.H.H. Processing network models for forest management. International Journal of Management Science, v.3, n.5, p.499$510,1995$.

CHAPPELLE, D.E. Linear programming for forest planning. In: CONVERY, F.J.; RALSTON, C.W. (Ed.) Forestry and Long - range Planning. Durham: Duke University, 1977. cap.4, p.129-178.

CONJUNTURA ECONÔMICA. Estatísticas macroeconômicas. Rio de Janeiro, v.51, n.5, Maio 1997.

COSTA, P.M. Breve história da evolução dos mercados de carbono. Silvicultura, n.76, p 24-33, set./dez. 1998.

COSTA FILHO, P.P.; COSTA, H.B.; AGUIAR, O.R. Exploração mecanizada da Floresta Tropical Úmida sem babaçu. Belém: EMBRAPA/CPATU, 1980. 38p. (Circular Técnica, 9)

DASSIE, C. Silvicultura no caminho do desenvolvimento sustentável. Celulose \& Papel, n.54, p.20-24, 1996. 
DEMPSTER, W.R. Industrial wood supply forecasting. In: ANNUAL MEETING MONTREAL, 1989. Anais. Montreal: CPAPA/ WOODLANDS SECTION, 1989. p.97-104.

DIAS, G.B.N.; TAUBE-NETTO, M.; SCHMIDT, M.B.; ROSSI, A.M.; LOPES, T.L. Planejamento Florestal Integrado. CVRD -Revista, v.5, n.15, p.35-50. 1984.

DOUGLAS, R.A. Trucks and roads: tune them together. In: ANNUAL MEETING MONTREAL, 1988. Anais. Montreal: CPAPA/ WOODLANDS SECTION, 1988. p.35-42.

DORNELLES, R. Tendências e perspectivas do setor florestal dos países do Mercosul. In: SEMINÁRIO DE ATUALIZAÇÃO EM SISTEMAS DE COLHEITA DE MADEIRA E TRANSPORTE FLORESTAL, Curitiba, 1998. Anais. Curitiba: FUPEF/UFPr, 1998.

DYKSTRA, D.P. Mathematical programming for natural resource management. New York: McGraw-Hill, 1984. cap.2, p.16-37: A graphical introduction to linear programming.

DURAN, D.O.; VALDEZ, P.F.; COROMINAS, E.R. Modelos econômicos matemáticos. Cuba: Universidad de La Habana, 1985. cap.4, p.235-309: Modelos de transporte.

DURATEX FLORESTAL. Exploração florestal de eucalipto. In: SIMPÓSIO BILATERAL BRASIL-FINLÂNDIA SOBRE ATUALIDADES FLORESTAIS. Curitiba, 1988. Anais. Curitiba: UFPr/IFPF, 1988. p.175-188. 
EQUIPE técnica da Cia Suzano de Papel e Celulose. Evolução do transporte florestal: experiência da Suzano. In: SEMINÁRIO DE ATUALIZAÇÃO SOBRE SISTEMAS DE EXPLORAÇÃO E TRANSPORTE FLORESTAL, Curitiba, 1992. Anais. Curitiba: UFPr, 1992. p.13-19.

EXAME. As melhores e maiores empresas do Brasil. São Paulo, 1996.

FAHRAEUS, L-B. Manual of logging and transport in Eucalyptus plantations. Roma: FAO/SWE/TF 142, 1974. 50p.

FLORESTAR ESTATÍSTICO. São Paulo, v.4, n.11, jul./out. 1996, 84p.

FUKUDA, S.; YUKUTAKE, K.; ISHIZAWA, H. A study on the transportation problems of timber in remote moutain area. Bulletin of the Faculty of Agriculture. - Miyazaki University, v.38, n.2, p.153-165, 1991.

GABARRO, J.; CHEVALIER, P.; WEINTRAUB, A.; NIETO, E.; EPSTEIN, R. A system for the design of short term harvesting strategy. European Journal of Operational Research, v.119, n.2, p.427-439, Dez. 1999.

GARCIA, O. Linear programming and related approaches in forest planning. New Zealand Journal of Forestry Science, v.20, n.3, p.307-331, Dec. 1990.

GREGERSEN, H.; NYLINDER, M. A model for the analysis of timber flow. Ekonomi-Forskningsstiftelsen-Skogsarbeten, n.4, 1979.

GRESHAM, G. Consumo em alta e oferta em baixa. Revista da Madeira, n.25, 1995. 
HADI, Y.; MOHAMED, S.; VINCENT, A. A microcomputer linear-programming log-allocation model for a Malaysian integrated timber complex. Resource Management and Optimization, v.6, n.2, p.153-164, 1988.

HADLEY, G. Programação linear. Rio de Janeiro: Guanabara Dois, 1982. 458p.

HAKKILA, P.; MALINOVSKI, J.; SIRÉN, M. Feasibility of logging mechanization in Brasilian forestry plantations. Helsinki: FFRI, 1992. 68p. (Relatório da cooperação técnica FFRI-UFPr)

HAUER, G.K. Timber management scheduling with multiple markets and multiple products. Minnesota, 1992. 12lp. Thesis (M.S.) - University of Minnesota.

HARSTELA, P. Decision support system in wood procuremente. A review. Silva Fennica, v.3, n.2, p.215-223, 1997.

HEDERSTROM, T. Ubicacion de las industrias forestales. In: SEMINÁRIO SOBRE EL TRANSPORTE DE LA MADERA EN PAISES DE AMÉRICA LATINA, Mexico, 1975. Anais. Roma: FAO/SIDA, 1975. p.198-208.

HIILIER, F.S.; LIEBERMAN, G.J. Introduction to operations research. 6.ed. New York: McGraw-Hill, 1995. 975p.

JOUMARD, R.; JOST, P.; HICKMAN, J.; HASSEL, D. Hot passanger car emission modelling as a function of instantaneous speed and acceleration. The Science of the Total Environment, v.169, p.167-174, 1995.

KARJALAINEM, T.; ASIKAINEM, A. Greenhouse gas emissions from the use of primary energy in forest operations and long-distance transportation of timber in Finland. Journal of Forestry, v.69, n.3, p.215-228, 1996. 
KEINER Jr., S. Produção e utilização de chapas de composição. Curitiba: Curso de Pós-Graduação, Engenharia Florestal, UFPr. 1993. (Notas de aula)

KORINEK, J. A method for the formulation of timber transport planning. Acta Universitatis Agriculturae, v.1, n.41, p.63-75, 1972.

KORPLAHTI, A. A system for analysing truck haulage of timber. MetsatehonKatsaus, n.12, 1989.

LEITE, A.M.P.; SOUZA, A.P.; MACHADO, C.C. Análise do ciclo de transporte de madeira para três tipos de caminhões. Revista Árvore, v.17, n.2, p.190-201, 1993. (Separata)

MARTELL, D.L.; GUNN, E.A.; WEINTRAUB, A. Forest management challengers for operational researchers. European Journal of Operational Research, v.104, p.1-17, 1998.

MARTINS, R.S. Racionalização da infra-estrutura de transporte no estado do Paraná: O desenvolvimento e a contribuição das ferrovias para a movimentação de grãos e farelo de soja. Piracicaba, 1998. 216p. Tese (Doutorado) DESR/ESALQ/Universidade de São Paulo.

McGUIGAN, B.N. A log resource allocation model to assist forest industry managers in process selection and location, wood allocation and transportation and production planning. Appitta, v.37, n.4, p.289-296, 1984.

MARTINI, E.L.; LEITE, N.B. Planejamento florestal: a importância e aplicação da programação linear. In: ENCONTRO BRASILEIRO DE ECONOMIA FLORESTAL, Curitiba, 1988. Anais. Curitiba: EMBRAPA/CNPF, 1988. 
MIYATA, E.S.; ZABINSKY, Z.B.; RIDEOUT, D.B.; MANN, C.N. Least cost analysis of log transportation. American Society of Agricultural Engineers, n.86-1605, 1986.

NEVES, M.R. Tendências dos mercados doméstico e internacional para produtos de base florestal. In: SEMINÁRIO DE ATUALIZAÇÃO EM SISTEMAS DE COLHEITA DE MADEIRA E TRANSPORTE FLORESTAL, Curitiba, 1998. Anais. Curitiba: FUPEF/UFPr, 1998.

NOVAES, A.G. Métodos de otimização: aplicação aos transportes. São Paulo: Edgard Blucher, 1978.

OIJALA, T.; TERAVA, J.; TOHU, J. Transportation of timber on barges. Metsatehon-Katsaus, n.10-93, 1993.

OLIVEIRA, A.J. O estado da arte do uso da pesquisa operacional no setor florestal brasileiro. In: SIMPÓSIO BRASILEIRO DE PESQUISA FLORESTAL, Belo Horizonte, 1993. Anais Viçosa: SIF/UFV, 1993. p.38-43.

ONDRO, W.J.; COUTO, L.; BETTERS, D.R. The status and practice of forestry in Brazil in the early 1990s. The Forestry Chronicle, v.71, n.1, p.107-119. Jan/Feb 1995.

PALANDER, T. A local DLP-GIS-LP system for geographically decentralized wood procurement planning and decision making. Silva Fennica, v.31, n.2, p.179-192, 1997.

PEREIRA, A.R.; PAULA JÚNIOR, G.G. Dimensionamento de uma frota de caminhões para transporte de carvão vegetal por meio de programação linear. IPEF Série Técnica, v.21, p.85-95, dez 1980. 
PEREIRA, A.R.; LADEIRA, H.P.; BRANDI, R. M. Minimização do custo total do transporte de carvão vegetal de eucalipto no estado de Minas Gerais. Revista Árvore / SIF, v.5, n.1, p.73-79, 1981.

PRICE, C.; MGENI, A.S.M. Planning of forest plantation investiment with the aid of linear programming: a case study of Sao Hill Forest, Tanzania. Forest Ecology and Management. v.62, p.51-72, July 1993.

RAJIVE, K.; RAWAT, J.; KUMAR, R. Application of linear programming to forest nursery planning. Indian Journal of Forestry, v 15, n.3, p.254-259, 1992.

RAMIREZ, P.F. Analisis tecnico y de costos de las faenas de carguio, transporte y estiba de rollizos de exportacion en la compañia agricola y forestal Copihue. Santiago, 1979. 113p. Monografia (Graduação) - Universidad de Chile.

RANDALL, A. Resource Economics. 2.ed. New York: John Wiley \& Sons, 1987. 325 .

REZENDE, J.L.; NEVES, A.R. Evolução e contribuição do setor florestal para a economia brasileira. In: SIMPÓSIO BILATERAL BRASIL-FINLÂNDIA SOBRE ATUALIDADES FLORESTAIS, Curitiba, 1988. Anais. Curitiba: UFPr, 1992. p.215-265.

RIBEIRO, B.A.M. Coordenação vertical do transporte de madeira: Análise empírica dos arranjos institucionais existentes na indústria brasileira de celulose. Piracicaba, 1998. 113p. Tese (Mestrado) - DEAS /ESALQ/ Universidade de São Paulo.

RODRIGUEZ, L.C.E. Programação linear no planejamento florestal: uma aplicação prática. Silvicultura, v.41, n.11, p.163-8. /Apresentado no 5. Congresso Florestal Brasileiro, São Paulo, 1986./ 
RODRIGUEZ, L.C.E.; MOREIRA, R.M. Gerenciamento de florestas de eucalipto com modelos de programação linear. IPEF Série Técnica, v.6, n.19, 1989.

ROITTO, Y. Optimization of roundwood transport. Silva-Fennica, v.9, n.1, p.7487, 1975.

ROSE, D.W.; EK, A.R.; HOGANSON, H.M.; AUBE, P. A spatial regional timber supply model for industrial expansion. Forest Products Journal, v.34, n.1, p.2127, 1984.

ROSS, A.D. Performance-based strategic resource allocation in supply networks. International Journal of Production Economics, v.63, n.2, p.255-266, 2000.

SEIXAS, F. Uma metodologia de seleção e dimensionamento da frota de veículos rodoviários para o transporte principal de madeira. São Carlos, 1992. 106p. Tese (Doutorado) - Escola de Engenharia de São Carlos/Universidade de São Paulo.

SEIXAS, F.; WIDMER, J.A. Seleção e dimensionamento da frota de veículos rodoviários para o transporte principal de madeira, utilizando-se de programação linear não inteira. IPEF - Série Técnica, v.46, p.107-18, 1993.

SILVA, C.R. O planejamento de sistemas de exploração de eucalipto para polpa. In: SIMPÓSIO SOBRE EXPLORAÇÃO, TRANSPORTE, ERGONOMIA E SEGURANÇA EM REFLORESTAMENTOS, Curitiba, 1987. Anais. Curitiba: UFPr/IUFRO, 1987. p.40-54.

SILVERSIDES, C.R. Survey of trucks for raw material transport. World Wood, v.17, n. 12, p.42-52, 1976. 
STAPE, J.L.; GARCIA, P.V.; MARTINI, E.L. Uniformização horária do volume e da composição qualitativa da madeira de Eucalyptus spp posto fábrica. In: CONGRESSO FLORESTAL BRASILEIRO, Curitiba, 1993. Anais. Curitiba: SBS, 1993. p.692-694.

TRAMPLER, T.; WDOWIAK, J. Optimization calculations in forestry. RocznikiNaouk-Rolniczych, (Monografia). p.132. 1983.

TOMASELLI, I. Mercado e comercialização de madeiras. In: SEMINÁRIO DO SETOR MADEIREIRO DO ESTADO DE MATO GROSSO, Cuiabá, 1998. Anais. Cuiabá: FIEMT, 1998. p.132-141.

UNIVERSITY OF CHICAGO. Programa LINDO: programação matemática linear, inteira e quadrática (software). San Francisco: The Scientific Press, 1991.

VARGAS, V.M. A adequação de planejamento para o transporte florestal. In: SEMINÁRIO DE ATUALIZAÇÃO SOBRE SISTEMAS DE EXPLORAÇÃO E TRANSPORTE FLORESTAL, Curitiba, 1989. Anais. Curitiba: FUPEF/UFPr, 1989. p.173-215.

VILLELA FILHO, A. Economia Florestal e interligações na exploração e transporte florestal. In: SEMNÁRIO DE ATUALIZAÇÃO SOBRE SISTEMAS DE EXPLORAÇÃO E TRANSPORTE FLORESTAL, Curitiba, 1992. Anais. Curitiba: UFPr, 1992. p.237-265.

WAGNER, H.M. Pesquisa Operacional. 2.ed. Rio de Janeiro: Prentice Hall, 1986.

WALTER, F.; CARLSSON, D. Internet open new doors: coordination and descentralization - new system leads the way. Forestry Research Institute, n.24, 1998. 
WILLIAMS, H.P. Model building in mathematical programming. 3.ed. Chichester: John Wiley \& Sons, 1993. 356p.

WORREL, A.C. Economics of american forestry. New York: John Wiley \& Sons, 1959. 441p.

WINTHER, M. Petrol passenger car emissions calculated with different emission models. The science of the total environment, v.224, p.149-160, 1998. 